\title{
BIOSSINTESE E ACÚMULO DE SACAROSE EM CANA-DE- AÇÚCAR (Saccharum spp): INFLUÊNCIA DO ION POTÁSSIO DURANTE DIFERENTES ESTADIOS DE CRESCIMENTO EM SOLUÇÃO NUTRITIVA
}

JOÃO SUZUKI

Orientador: Prof. Dr. OTTO JESU CROCOMO

Tese apresentada à Escola Superior de Agricultura "Luiz de Queiroz", da Universidade de São Paulo, para obtenção do Título de Doutor em Agronomia. Área de Concentração: Solos e Nutrição de Plantas.

P I R A C I C A B A

Estado de São Paulo - Brasil

Dezembro, 1982 
Aos meus pais,

YOSABURO SUZUKI

("in memorian")

e

SHIN SUZUKI,

OFEREÇO

A minha esposa,

VERA LOCIA,

Aos meus filhos, JUNIOR, ENEAS E THIAGO, 


\section{AGRADECIMENTOS}

AO PROF. DR. OTTO JESU CPOCOMO, pela brilhante atua ção na difícil missão de orientador.

Ao DR. ENEAS SALATTI, DD. Diretor do Centro de Ener gia Nuclear na Agricultura - CENA - USP, e do DR. ARISTEU MEN DES PEIXOTO, DD. Diretor da E.S.A. "Luiz de Queiroz" - USP, Pi racicaba, pela possibilidade oferecida.

AO PROF. DR. AILTO ANTONIO CASAGRANDE e PROF. DR. WANDERLEY JOSE DE MELO, DDs. Diretor e Vice-Diretor da FCAVJ, "Campus" de Jaboticabal - UNESP, pelo apoio e incentivo.

Ao Conselho Nacional de Desenvolvimento Cientifico e Tecnológico - CNPq, pela bolsa de estudos de Pós - Graduação concedida.

Ao Instituto Internacional da Potassa, na pessoa do Eng? Agro TSUIOSHE YAMADA, DD. Coordenador do Programa Comum no Brasil, pelo auxilio financeiro concedido.

Aos docentes e demais funcionārios do Departamento de Tecnologia da FCAVJ, "Campus" de Jaboticabal - UNESP, nas pessoas de seu Chefe, DR. RAUL ROBERTO DE SOUZA FALEIROS e Sub - Chefe, DR. MARIA AMALIA BRUNINI KANESIRO.

Aos tēcnicos ENIO T. OLIVEIRA, do CENA, è FÃTIMA RIBEIRO HARNICH, da FCAVJ, pela colaboração nos trabalhos de laboratório. 
Aos colegas CLARICE, CARLOS, CRISTINA, IRENICE, DUL CE, NEETALI, ILBENIZIO e demais funcionários do setor de Bioqui mica de Plantas do CENA, pela amizade e convívio.

A LUIZA MARIA VILLANOVA pelos serviços de datilogrą fia.

Agradecimentos ainda são devidos a todos os que, di reta ou indiretamente, contribuiram para o desenvolvimento des te trabalho.

Em especial, agradecimentos são devidos à minha es posa, VERA LŨCIA, pelo apoio e dedicação sempre constantes.

Einalmente, Graças são rendidas ao nosso supremo Orientador do Universo, pela "nossa existência". 
"BIOSSÍNTESE E ACÚMUlo DE SACAROSE EM CANA-DE-AÇUCCAR (Saccharum spp): INFLUENCIA DO ION POTÁSSIO DURANTE DIFERENTES ESTÁDIOS DE CRESCIMENTO EM SOLUÇÃO NUTRITIVA"

Autor:

João Suzuki
Orientador:

Prof. Dr. Otto Jesu Crocomo

RESUMO

Avaliou-se a atividade às enzimas invertase ácida e alcalina e sintetase de sacarose em tecidos vegetais de cana de açúcar (Saccharum spp) cv. NA56-79, durante seu crescimento, relacionado ainda com diferentes concentrações de potássio for necido à solução nuirritiva, na qual as plantas foram cultivadas.

As plantas não deficientes em potássio iniciaram o acümulo de sacarose aos 90 dias, nos entrenós basais (3: e 4\%), os quais foram selecionados para as anălises, além das folhas 3. e 4. e respectivas bainhas. Até aos 6 meses de idade (perío do de análises) estes entrenós acumularam aproximadamente 16-17\% de sacarose no caldo, Nestas plantas, a avaliação enzimáti ca revelou atividades normais de invertases nas folhas, sendo que nas bainhas foliares as invertases ácida e alcalina se dife renciaram com a maturação, com tendência para diminuição da ácí da e aumento da alcalina. Por sua vez, a sintetase de sacarose não apresentou tendência definida. 
Em plantas deficientes em potássio as invertases apresentaram atividades reiativamente mais elevadas, principal mente nas folhas, sugerindo a existência de uma maior concentra ção molar destas enzimas. Nestas plantas, o acúmulo de sacarose foi insignificante. 


\section{"BIOSYNTHESIS AND ACCUMULATION OF SUCROSE IN SUGARCANE STORAGE TISSUES (Saccharum spp): INFLUENCE OF POTASSION ION DURING DIF FERENT GROWTH STAGES IN WATER SOLUTION"}

Author:

João Suzuki

\section{Adviser:}

Prof. Dr. Otto Jesu Crocomo

SUMMARY

The activity of acid and neutral invertases and su crose synthetase enzymes was evaluated in plant tissues of su garcane (Saccharum spp) cv. NA56-79 during growth and also rela ted to different potassium ion concentrations added to the growth nutrient solution.

Plants without potassium deficiency initiated sucro se accumulation at 90 days ir the $3^{\text {rd }}$ and $4^{\text {th }}$ basal internodes selected for study, as well as in the $3^{\text {rd }}$ and $4^{\text {th }}$ leaves and respective leaf-sheaths. At 6 months of age, these internodes accumulated approximately 16\%-17\% sucrose in the juice. These plants showed normal leaf invertase activity. In the leaf-sheaths, the acid and neutral invertases differed with ripe ning, with a tendency for the acid to decrease and the neutral to increase. On the other hand, no defined activity was obser ved for sucrose synthetase.

In K-deficient plants the invertase activity were greater, principally in leaves, which suggests the existance 
of greater molar concentration of these enzymes.

In these plants sucrose accumulation was insignificant. 
1. INTRODUÇÃO $\ldots \ldots \ldots \ldots \ldots \ldots \ldots \ldots \ldots \ldots \ldots \ldots \ldots$

2. REvisão de Literatura ............... 4

2.1. Biossintese de Sacarose ........... 4

2.2. Acǘmulo de Sacarose $\ldots \ldots \ldots \ldots \ldots . \ldots . . . . .8$

2.3. Função Enzimática do Ion $\mathrm{K}^{+} \ldots . . . . . .13$

2.4. Efeito do $\mathrm{K}^{+}$na Fotossintese $e$

Translocação de Fotossintatos ...... 16

3. MATERIAL E mETODOS .................... 18

3.1. Material. .................... 18

3.2. Mëtodos $\ldots \ldots \ldots \ldots \ldots \ldots \ldots \ldots \ldots . \ldots \ldots$

3.2.1. Soluçăo Nutritiva ........ 3.8

3.2.2. Obtenção das Plantas ........ 19

3.2.3. Delineamento Experimental ... 20

3.2.4. Amostragens e Preparo ....... 20

3.2.5. Códigos Utilizados nas Amostras $\ldots \ldots \ldots \ldots \ldots \ldots . \ldots . \ldots 23$

3.2.6. Metodologia Analitica ...... 23

4. RESUITAdOS E DISCUSSÃO $\ldots \ldots \ldots \ldots . \ldots \ldots$

4.1. Desenvolvimento e Acúrnulo de

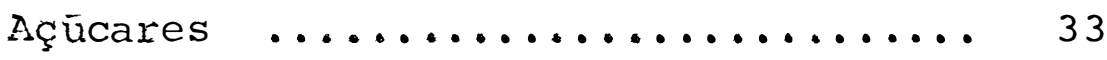

4.2. Interações Potássio/Atividade Enzimática 
5. CONCLUSÕES $\ldots \ldots \ldots \ldots \ldots \ldots \ldots \ldots \ldots \ldots \ldots . \ldots \ldots$

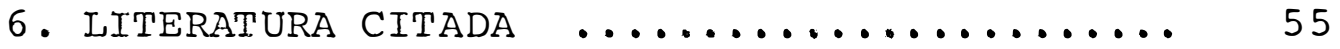

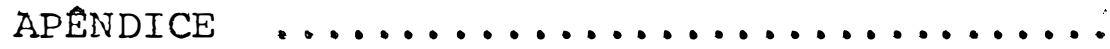




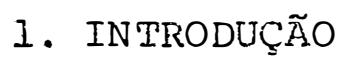

Estudos relacionados com o mecanismo de acúmulo

de sacarose nos tecidos de armazenagem da cana-de-açúcar tem mostrado importantes conclusões sobre a função fisiológica das enzimas invertases em plantas (SAMPIETRO et alii, 1980).

Por outro lado, esta sacarose deverá antes ser Diossintetizada nos tecidos e depois translocada até as células de armazenamento, envolvendo a atividade de outras enzimas, prin cipalmente as sintetases e, mais especificamente, a sintetase de sacarose e a sintetase de sacarose fosfato (ALEXANDER, 1973). Bas tante relacionado com estas enzimas e participando principal mente como ativador se encontra o cátion monovalente $\mathrm{K}^{+}$, que se gundo EVANS \& WILDES (1971) é ativador das enzimas do grupo das sintetases, oxidoredutases, desidrogenases, transferases e cina ses.

As enzimas invertase e sintetase da sacarose, de sempenham funções específicas e que, juntas, respondem principal mente pelo metabolismo bioquímico de síntese e armazenamento de 
sacarose em cana-de-açūcar. O acúmulo de sacarose ocorre tanto em tecidos imaturos como em tecidos adultos. Todavia, nos teci dos imaturos esta sacarose é rapidamente hidrolizada pela ativi dade da enzima invertase ácida vacuolar e as hexoses resultan tes são utilizadas no citoplasma durante o metaboIismo de cres cimento celular. Em tecidos adultos, a invertase ācida vacuolar sofre um rāpido declíneo e a invertase vacuolar alcalina passa a predominar. Esta invertase alcalina ou neutra opera em conjun to com a invertase ācida, no controle do acūmulo ativo da saca rose no vacuolo (ALPXANDER, 1973).

Segundo GAYLER \& GLAZIOU (1972), è desconhecida a utilização ảireta da sacarose no metabolismo de plantas su periores, exceto após a hidrólise pelas invertases ou como pro duto do inverso da reação de UDPG pela D-Frutose 2- glicosiltransferase. Ainda, segundo os citados autores, uma parte destas in vertases (invertases dos espaços intercelulares) é secretada durante a fase de formação das células, pré-determinando nes tas a ãisponibilidade de carboidratos metabolizados nas próxi mas etapas de crescimento e maturação.

Assim, observa-se que um melhor conhecimento so bre aspectos bioquímicos nesta área pode contribuir decisiva mente em âmbitos prāticos da exploração da cultura da cana de açúcar, sendo que o nível de atividade da invertase vacuolar po derá fornecer informações prévias quanto à capacidade da planta em acumular carboidratos totais ou especificamente acumular sa carose. 
Estudos sobre a atividade das invertases àcida e neutra, em tecidos maduros de diversos híbridos de Saccharum spp, feitos por HATCH \& GLAZIOU (1963), indicaram a existência de alta atividade de invertase alcalina em todos os hibridos de maior capacidade de acumular açúcares.

Todas estas informações tornam clara a necessida de de se estudar a evolução deste processo multienzimático des de a fase inicial até o ponto de măximo acúmulo de sacarose no colmo maduro. SAMPIETRO et alii (1.980) mostra uma correlação existente entre o padrão enzimătico do colmo em crescimento e a bainha foliar, sendo de grande importância o fato de se po der estudar a evoluçao enzimática no colmo, utilizando-se a bainha foliar da planta. Observa-se que maiores detalhes sobre as interações enzimáticas, como o processo de biossíntese e acū mulo de sacarose nos colmos de cana-de-açücar, são de grande valor para um melhor aproveitamento desta cultura.

$$
\text { Assim, o objetivo do presente trabalho foi }
$$

de acompanhar a influência do potássio sobre as interações en tre as atividades das enzimas invertases e sintetaze de sacaro se com a biossintese de sacarose nas folnas e seu acúrnulo no colmo de cana de açūcar cultivada em solução nutritiva. . 
2. REVISÃO DE LITERATURA

2.1. Biossíntese de Sacarose

A sacarose ê formada como um resultado da assimi lação fotossintētica do $\mathrm{CO}_{2}$ eficazmente em todas as plantas sü periores. Sua importância estā ligada ao fato de ser o açücar mais abundante nas plantas, e no mundo, o principal açūcar co mercializado. Nas plantas, a sua função ë como constituinte de reserva para a respiração, sendo a energia liberada utilizada para numerosas atividades metabölicas. Dentre estas, destaca-se a sintese de aminoācidos proteínas e lipídeos e outros compos tos orgänicos.

A maneira como esta sacarose é sintetizada nas folhas tem mobili.zado, hã longo tempo, a atenção dos pesquisadọ res de plantas. Recentemente a descoberta de que à sacarose é a principal forma de translocação de carboidratos, mais o fato de que esta não è. a. forma mais prontamente acumulada em células imaturas de armazenamento tem indicado que a molécula de sacaro 
se pode ser sintetizada invertida e resintetizada vārias vezes antes de cumprir o seu destino fisiolögico.

Durante muito tempo, os fisiologistas estiveram incertos sobre quem era fotosintetizado primeiro, se os açüca res simples, os dissacarídeos sacarose ou se era a amido. Atual mente prevalece a teoria de que D-glicose e D-frutose são os produtos primários da fotossíntese e que se combinam enzinatica mente formando a sacarose.

Um novo problema surgiu, como sendo a maneira co mo se ligava as hexoses para originar a sacarose. Durante quase meio século de estudos novas hipóteses foram lançadas sendo que na década de 40, com o conhecimento da biosssíntese de gii cogênio via fosforilase, o inverso da fosforölise da sacarose foi obtido em preparado de bactërias (Pseudomonas saccharofiza) con tendo a enzima sacarose fosforilase (HASSID \& DOUDOROF, I950 e HASSID \& PUIMAN, 1950). Estava concretizado um sistema natural enzimätíco de produção de sacarose autênticá. Todaviá, este pro cesso não era detectado em tecidos de plantas superiores.

Somente a partir dos anos 50 é que os mecanismos responsáveis pela biossíntese da sacarose na sua abundância na tural foram descobertos. Daí por diante, as enzimas sintetase de sacarose 6-fosfato e sintetase de sacarose foram finalmente isola. das a partir de numerosas espécies de plantas e pode se demons trar serem as duas distintas entidades capazes de sintetizar em comum uma autêntica ligação da sacarose (ALEXANDER, 1973). 
Buchanan et alii. (1952-1953). citados por CARDINI et alii (1955) e ALEXANDER (1973) com experimentos usando ele mentos traçadores, identificaram entre compostos fosforilados de folhas de algas e folhas verdes expostas a ${ }^{14} \mathrm{CO}_{2}$, $\circ$ UDPG (Uridina di.fosfoglicose) como sendo um metabōlito ativo de fo lhas verdes fotossintetizadoras. Quase que imediatamente propu seram que este UDPG era um precursor relacionado com a sinte se de sacarose. Tal hipótese foi reforçada por CARDINI et alii (1955) que mostraram a equivalência entre diminuiçāo de UDPG e a formação de UDP e sacarose, utilizando-se de germe de trigo, sorgo sacarino, beterraba, cana-de-açūcar e sementes de ervi 1ha. Foi observado ainda que esta enzima năo erá inibida por arsenitos, fluoretos, iodoacetato, pirofosfato até a concen tração de 0,03M e por 8-hidroxiquinoleina ou EDTA (ácido etile nodiamino tetracético dissōdico) até $0,2 \%$ de saturação.

Em cana-de-açūcar a síntese de sacarose é reali rada primeiramente nas folhas, sendo as enzimas sintetase de sa carose sintetase de sacarose fosfato detectadas em extrato foli.ar (FRYDMAN \& HASSID, 1963) e mais especificamente nos cloroplas tos (HAQ \& HASSID, 1965).

A enzima sintetase de sacarose em batata imatura, se gundo PRESSEY (1969) pode desempenhar sua atividade tanto na sintese como na hidrólise da molécula de sacarose, sendo a ati vidade de síntese superada pela atividade hidrolítica a $37^{\circ} \mathrm{C}$ e $\mathrm{pH} \cong 6,5$, tendo como substrato o UDP. Todavia, durante a ma turação a atividade desta enzima decresce significativamente, 
indicando estar tal enzima,ligada ao sistema de regulação da sintese de amido a partir da sacarose, cujo teor é elevado em

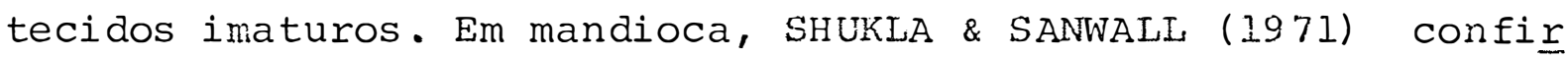
mam esta teoria, "uma vez que a enzima sintetase de sacarose uitili za como substrato tanto UDPG como ADPG (Adenosina difosfoglicose) que por sua vez tambëm são doadores de glicose na síntese de ami do.

Porém, em cana de açūcar que é uma planta que acumula sacarose nos colmos maduros, a atividade da enzima sin tetase de sacarose desempenha atividade especificamente de sínte se (HATCH et alii, 1963), estando a hidrölise mais especifica mente a cargo das invertases vacuolares que hidrolisam a saca rose (no compartimento metabólico foliar), formando as hexoses glicose e frutose (HAWKER \& HATCH, 1965 e SLACK, 1966).

Segundo HART et alii (1962) em estudos sobre a translocação de sacarose ${ }^{14} \mathrm{C}$ em cana-de-açúcar demonstrou que a sacarose formada nas folhas adulias rapidamente segue para o sistema condutor (nervuras secundárias) e move-se primeiramer te para baixo, passando para a nervura central foliar seguindo para a bainha em velocidades além de $2,5 \mathrm{~cm} / \mathrm{minuto.} \mathrm{Uma} \mathrm{vez} \mathrm{no}$ colmo, uma fração segue para baixo e outra para cima com velo cidade media de $84 \mathrm{~cm}$ /hora.

I. sacarose que chega nas raizes, folhas e caules jovens é convertida a glucose e frutose que é usada no crescí mento de paredes celulares e protoplasma.

Nesta etapa as enzimas invertases parecem desem penhar importante papel no mecanismo de controle da enérgética e 
biossintese celujar, que pode ser avaliado pelo nível de ativi dade desta enzima (SAMPIETRO et alii, 1980).

2.2. Acúmulo de Sacarose

Inümeros esquemas tentando explicar o mecanismo de acūmulo de sacarose nos vacuolos das células, foram apresen tados, iniciando com GLAZIOU (1961), mostrando as interconver sões e acúmulo de açūcares em tecido de armazenagem de cana de açūcar. A seguir, HA⿱T⿰C丨 \& GLAZIOU (1963) representaram um es quema mais completo, explicando o ácūmulo, considerando a sacá rose dos tecidos condutores (floema), passando para o espaço. externo do tecido parenquimatoso, onde sofre ação de invertą ses. A glicose e frutose penetram o compartimento metabólico da céiula do parenquina determinando pela concentração, uma re gujaçäo na atividade das invertases no interior do compartimen to de acümulo. Ao mesmo tempo, estas hexoses sofrem um proces so rāpido de interconverșsão e fosforilação.

Neste processo inümeras enzimas estão presentes para assegurar a quantidade adequada de UDPG, frutose e fruto se 6-P para a sintese de sacarose. Segundo ALEXANDER (1973), en tre as enzimas essenciais parece haver abundância das chexoqui nases (fosforilaçäo da glicose e frutose); fosfohexose isomera se (interconversão da glicose 6-P e frutose 6-P), UDPG frutose 6-P transglicosilase (síntese de sacarose e sacarose fosfato); numerosas fosfatases não específicas e uma sacarose P. fosfata 
se específica. INão hā conhecimento de nenhuma cinase envolvi da na síntese direta da sacarose fosfato através de sacarose mais ATP.

A formação da sacarose fosfato está relacionada com o mecanismo de passagem da sacarose do compartimento meta bölico para o espaço interno que ocorre como um processo ati vo, uma vez que a concentração deste açŭcar é grande no espaço interno. Assim, a quebra desta ligação fosfato fornece energia pára a entrada da sacarose no vacuolo onde é efetivamente acu mulac̉a (HATCH, 1964). Porëm, esta sacarose vacuolar està sob a 3.çăo de invertase, que nos tecidos ainda em crescimento é hi drolizada fornecendo hexoses que retornam livremente ao compar timento metabōlico e espaço externo do parenquina, sendo uti.ji. zada nos processos de obtenção de energia e elementos para sín tese proteica.

A invertase "vacuolar", responsável por esta hi drólise nos vacuolos de células de tecidos, imaturos appresentà atj.vidade måxima em $\mathrm{pH}$ ácido, sendo chamada de invertase ácida. Uma outra invertase, "neutra ou alcalina", com atividade máxi ma em $\mathrm{pH} \cong 7,0$, aumenta durante a maturação, existindo correlä ção entre o nível de atividade desta enzima com a concentração de hexoxes. Esta enzima parece fazer parte do sistema controla dor do fluxo de açücares em tecidos adultos de armazenagem (GAYLER \& GLAZIOU, 1972).

Observa-se nesta etapa (maturação), na atividade 
da enzima invertase ácida solúvel dos espaços intercelulares ${ }^{(*)}$ um declínio com uma curva de decaimento de la ordem, com meia vida aproximada de $13-16$ dias (t $1 / 2)$, apresentando um entrenó maduro, baixa atividade de invertase ácida solüvel citoplasmā tica e uma atividade quase nula para invertase àcida vacuolar, que è justamente onde a sacarose é efetivamente acumulada. Ain da, segundo GAYLER \& GLAZIOU (1972) a irivertase ä́cida solúvel do espaço intercelular é secretada durante a fase de formação celular na região do meristema. A medida que a célula é distan ciada da zona meristemática ela se alonga e se torna madura e a quantidade de carboidratos disponívei para estas células du rante a fase de crescimentoé predeterminada pela quantidade de invertases previamente secretadas nos espaços intercelulares do tecido parenquimatoso. Nenhuma enzima mais é secretada e aquelas existentes são lentamente inativadas (GAYLER \& GLAZIOU, 1972). Conforme observam HATCH \& GIAZIOU (1963), células madu ras contêm invertases àcida insolúvel ligadas à parede celular e invertases neutras.

Esta troca de invertases àcida para neutra ou al calina, quando o tecido se torna adulto, foi comprovada e elu cidada pelo estudo da cinētica das invertases em cana de açū car feito por SAMPIEIRO et alii (1980) onde os autores mostram que a frutose é um inibidor competitivo para a invertase àcida

${ }^{(*)}$ Os autores referem-se a esta enzima como "soluble outer space invertase". 
e que uma alta concentraçăo de sacarose pode suprimir parcial mente ou completamente a função reguladora da invertase ácida, cuja função passa a ser efetuada pela invertase alcalina, gra dativamente, indicando a maturidade do tecido preparado para o acūmulo de sacarose.

SILVEIRA (1980) observou em cana de açúcar culti vada em solução nutritiva, com idade de 2 e 4 meses, um grande decrēscimo na concentração de açúcares redutores e de sacarose (embora maior nos caules) tanto nas folhas, como nos caules, sendo acusada neste mesmo periodo a maior taxa de crescimento e a maior intensidade na síntese de proteínas, mostrando que apesar da alta taxa de produçäo de fotossintatos (açúcares) o processo efetivo de acúmulo de sacarose nos colmos ainda não ocorre neste período. Entre o período estudado de 4-6 meses, observou-se um grande : ncremento no teor de sacarose, tanto nas folhas como nos colmos, sendo provável que neste estágio, já tenha iniciado o processo de acúmulo de sacarose nos colmos. Segundo ALEXANDER (1973), o movimento cíclico de açúcares em tecidos imaturos de armazenamento, serve para aten der a 2 objetivos: a) criar um sistema tampão para prevenir uma grande flutuação no suprimento de açúcares no citoplasma e b) prevenir uma alteração excessiva no potencial osmōtico va cuolar, que serve como fator de força para promover a expansão celular. O sistema tampão é regulado em parte pelo mecanismo de controle do complexo de funcionamento para a invertase ácida vacuolar. 
Em cana de açücar, a atividade desta enzima pode ser estudada na bainha foliar que é justamente o suporte dos órgãos condutores através do qual. o dissacarídeo passa para o parenquina de armazenamento do caule. Este órgão liga o limbo foliar (local de síntese) ao colmo (local de armazenamento) e, portanto, deve reunir invertases adaptadas à característica fun cional do limbo foliar e também a invertase presente nos teci dos de armazenamento (SAMPIETRO et alii, 1980).

Conforme foi ainda observado, aparentemente a in vertase não ē uma enzima de membrana, uma vez que foi detecta do sua atividade somente na fração solúvel dos tecidos do coll mo em crescimento e da bainha foliar. O colmo em crescimento apresenta invertase ăcida solüvel, e invertase ligada à parede celular. No caso da bainha foliar foi observado um padrão seme Ihante, com a enzima solúvel que apresentou 2 categorias, como sendo um menor componente de $\mathrm{pH}$ ötimo de 2,0 e o componente mais importante com pH ötimo de 5,0-5,5. Alëm disso, a inver tase ācida solüvel ligada à parede celular da bainha foi detec tada (resultado não publicados). Consequentemente, a enzima de pH 5,5 da bainha foliar está relacionada com a invertase vacuo lar do colmo em crescimento e a mesma localização vacuolar po de ser considerada (SAMPIETRO et alii, 1980). 
2.3. Função Enzimātica do Ion $\mathrm{K}^{+}$

O K entre outros cátions monovalentes são cofá tores necessários para muitas enzimas catalizadoras de determi nadas etapas do metabolismo. Tem sido evidenciado a necessida de destes cátions monovalentes para a "sintetase do amido" e para a atividade de uma série de enzimas participantes na sín tese proteíca.

Em relação ao mecanismo da ativação pelo potāssio, pode-se citar que: a) a estrutura subunităria de algumas enzi mas é dependente do tipo de cātion monovalente presente; b) a capacidade de algumas enzimas de se ligar a uma determinada co enzima é influenciada pelo cátion ${ }^{+}$; c) cátions monovalentes tais como o $\mathrm{K}$ pode ter efeito a lostérico; d) os cātions ${ }^{(+)}$po dem influenciar na conformação de algumas enzimas, sem no en tanto causar alterações na estrutura física; e) cātions ativa dores monovalentes podem estabilizar reações intermediārias dü rante uma catálize enzimática, ou influenciar na ação catalítí. ca por processos ainda não mui to bem explicados.

Todas estas funções do $\mathrm{K}$ implicam numa série de consequëncias quando de sua deficiēncia, dentre os quais apre sentam-se mais consistentes os seguintes: a) redução de carboí dratos solúveis e acúmulo de açúcares; b) menor sintese de ami do e glicogênio; c) acúmulo de amino àcido; d) bloqueio na sín tese proteica; e) abaixamento da taxa de utilizaçäo dos sub tratos respiratōrios e f) diminuição da taxa de fosforilação 
oxidativa e fotofosforilação. Isto mostra claramente a influên cia do K sobre uma série de diferentes processos metabólicos, onde, as enzimas catalizadas por cátions monovalentes $\left(\mathrm{K}^{+}\right)$são principalmente os do grupo das sintetases, oxidoredutases, de sidrogenases, transferases e quinases (EVANS \& WILDES, 1971). Esta ligação do cātion $\mathrm{K}^{+}$com a atividade enzjmá tica atualmente se encontra bastante comprovada, sendo observa do inúmeros efeitos, quando de sua deficiẽncia (LIEBHARDT, 1968), principalmente a sintese de aminas tóxicas tais como putresci na e agmatina (CROCOMO et alii, 1970; BASSO \& SMITH, 1974) sen do observado o acūmulo destas aminas, principalmente em folhas velhas (MENGEI \& KIRKBY, 1978).

Segundo THOMAS et alii (1959), em homogenado cru de follhas de batata doce, a fixação de $\mathrm{CO}_{2}$ via P.E.P. carboxi lase, é estimulada pelo magnésio e não pelo $\mathrm{K}^{+}$. Todavia, o ho mogenado com $\mathrm{K}$-suficiente apresentou-se mais ativo do que no meio $\mathrm{K}$-deficiente. A teoria para explicar este fato, é que o $\mathrm{Mg}^{2+}$ é o ativador da enzima, e que $\circ \mathrm{K}^{+}$poderia estar envolvi do com a sintese desta enzima.

OZBUN et alii (1965) observaram em feijoeiro que a deficiência de $\mathrm{K}$ aumentou a taxa de respiração, com conse quente abaixamento do teor de açücares.

EVANS \& SORGER (1966) e SUELTER (1970 e 1974), lançaram a idéia de que uma alta concentração de $\mathrm{K}^{+}$é necessá ria para a ativa conformação de muitas enzimas participantes no metabolismo intermediário e biossínteses. Atualmente, segun 
do CLARKSON \& HANSON (1980) a necessidade nutricional do $\mathrm{K}^{+}$es tá relacionado com 4 funções fisiológico-bioquímicas: 1) ativa ção enzimātica; 2) processos de transporte através de membra nas; 3) neutralizaçăo de anion e 4) potencial osmótico estando as 2 ültimas ligadas entre si.

Outro problema, está relacionado com a especifi cidade, que se encontra ainda sem resposta. Provavelmente exis tem ions que o substituem. O íon $\mathrm{NH}_{4}^{+}$atravēs da ligação de $\mathrm{H}$ e reações de amidação, contribui para a toxidez de $\mathrm{NH}_{4}^{+}$in vivo. Já é fato conhecido que $\mathrm{Na}^{+}$e $\mathrm{Rb}^{+}$apresentam algum : efeito controlador na deficiência de $\mathrm{K}^{+}$, que o substitui em sua fun ção de controle do potencial osmótico (RAINS, 1976). Bioquimi camente, $\mathrm{Rb}$ e $\mathrm{NH}_{4}^{+}$são geralmente os melhores substitutos do $\mathrm{K}^{+}$ na ativação de enzimas isoladas (EVANS \& SORGER, 1966; SUEITER, 1970 e 1974), sendo conhecido o estímulo provocado por $\mathrm{Rb}^{+}$e

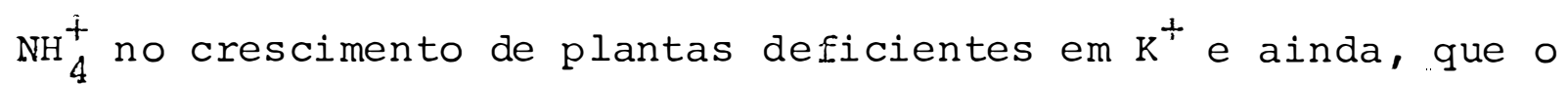
$\mathrm{Rb}^{+}$pode substituir $\circ \mathrm{K}^{+}$nos processos de transporte ativo (EPSTEIN, 1972), sendo $0^{86} \mathrm{Rb}^{+}$usado como elemento traçador do K.

Desde que $\circ \mathrm{K}^{+}$pode ser substituŕdo até certo grau, no seu papel fisiológico e bioquímico, qual a proprieda de então que o coloca como elemento essencial na planta? Para tanto, inúmeros estudos com estes cātions monovalentes foram efetuados, visando explicar a alta especificidade nutricional atribuída ao $\mathrm{K}^{+}$. Alguns fatos puderam ser delineados, sendo que: a) algumas enzimas mostram elevada exigēncia de $\mathrm{K}^{+}$, e que 
se forem substituídas por $\mathrm{NH}_{4}^{+}$e $\mathrm{Rb}^{+}$estas atingiriam nĩveis tó xicos à célula viva. O $\mathrm{K}^{+}$, por outro lado, $\overrightarrow{\mathrm{e}}$ biologicamente inócuo exceto a concentrações de salinidade. b) Alguns sítios ativos de enzimas envolvem complexação e o $\mathrm{K}^{+}$satisfaz esta exigência, pois, existe em quantidades abundantes. c) As cêlu las vegetais requerem abundantes quantidades de cátions para neutralizar ácidos orgânicos e grupos amoniacais de macromolé culas e pará abaixar o potencial da água. Esta necessidade è satisfeita por cátions monovalentes que são pobres antagonis tas, para os sitios que requerem cátions bivalentes (CLARKSON \& HANSON, 1980).

2.4. Efeitos do $\mathrm{K}^{+}$na Fotossintese e Translocação de Fotossintatos

Inümeros autores têm observado a participação do $\mathrm{K}^{+}$nos processos de translocação de fotossintatos em cana de açūcar. HART (1969) demonstrou a natureza do efeito do $\mathrm{K}^{+}$na translocação de produtos marcados da fotossíntese nesta cultü ra.

Segundo HAEDER \& MENGEL $(1974)$, o ion $\mathrm{K}^{+}$, tanto auxilia na assimilação do $\mathrm{CO}_{2}$, como tambēm parece beneficiar na translocação dos fotossintatos, funcionando como um meio in direto de aumentar a taxa de assimilação de $\mathrm{CO}_{2}$. Sob condições controladas de $\mathrm{CO}_{2}$, mostrou-se que altos níveis de $\mathrm{K}^{+}$resulta ram em aumento na taxa de translocação de fotossintatos (HART, 1970 e MENGEL \& VIRO, 1974 ). 
O efeito do $\mathrm{K}^{+}$sobre a translocação de fotossin tatos, parece estar mais diretamente relacionado com 0 proces so de fotofosforilação (HART, 1970). Em condições de níveis elevados de $\mathrm{K}^{+}$, ocorre, provavelmente, a estimulação na produ çăo de ATP, que é requerido na carga do tubo crivoso com fotos sintatos. Estes fatos, estão de acordo com PFLUGER \& MENGEI (1972), que observaram aumento tanto na taxa de fotofosforila ção como no transporte de eletrons, quando as plantas tiveram suprimento adequado de $\mathrm{K}^{+}$.

As funções do ATP alēm da carga no tubo crivoso de fotossintatos, ainda é requerido numa série de processos bio químicos endergônicos tais como assimilação de $\mathrm{CO}_{2}$, síntese de compostos de elevado peso inolecular e na redução do $\mathrm{N}_{2}-\mathrm{NH}_{3}$ nos nōdulos radiculares. Deste modo, o efeito do $\mathrm{K}^{+}$na síntese fotossintētica de ATP, influencia indiretamente nestes proces SOS (MENGEL \& KIRKBY, 1978). 
18.

3. MATERIAI E METODOS

3.1. Material

Conduziu-se o ensaio em casa de vegetação do Cen tro de Energia Nuclear na Agricultura - CENA, em Piracicaba SP, utilizando-se soluçäo nutritiva como meio de crescimento em recipientes de plástico com capacidade para 3 e 10 litros de solução.

o material vegetal foi obtido a partir de gemas

de plantas adultas de cana-de-açúcar ( 12 meses de idade) Sacch $\underline{x}$ mum spp CV. NA56-79 selecionadas e cedidas pelo Planalsucar de Araras - SP .

3.2. Métodos

3.2.1. Solução Nutritiva

Utilizou-se a solução nutritiva completa segundo HOAGLAND \& ARNON (1950), diluindo na proporção $1: 10$ como supor 
te inicial de crescimento, que foi aplicado nos intervalos de irrigação, até aos 30 dias após a brotação.

A solução nutritiva de trabalho foi preparada tambēm segundo HOAGLAND \& ARNON (1950), porëm, com omissão do potássio (solução base), o qual foi adicionado separadamente nas proporções de: 0,$1 ; 3,0 ; 6,0 ; 9,0$ e 12,0 p.mg de $\mathrm{K}^{+} / 1$ itrode solução. Utilizou-se como fonte de potássio o $\mathrm{KCl}$ corresponden do cada dose, aos tratamentos $\mathrm{K}_{1}, \mathrm{~K}_{2}, \mathrm{~K}_{3}, \mathrm{~K}_{4}$ e $\mathrm{K}_{5}$, respectivą mente.

O pH destas soluçöes variou de 6,0 a 7,0 durante o decorrer do experimento.

\section{2 .2 . obtenção das Plantas}

Os colmos das plantas-mães foram lavadas em âgua corrente, sendo seíecionadas as gemas localizadas no terço mê dio. Estas gemas, retiradas juntamente com a porção suculenta do entrenó, sofreram tratamento térmico a $51^{\circ} \mathrm{C}$ de acordo com SILVA (1976) (tratamento preventivo contra raquitismo) e este rilização com solução a 1\% de hipoclorito de sódio.

A brotação foi efetuada em vermiculita esteri lizada, saturada com soluçäo de $\mathrm{CaSO}_{4} \mathrm{j}^{-4} \mathrm{M}$ e mantidos em cāma ra de germinação e crescimento. Quando as plantas atingiram o estádio de desenvolvimento adequado (30 dias), foram transferi das para as soluçöes nutritivas de trabalho contidas ern reci pientes de plástico com volume de 3,0 litros, mantidas com ae 
ração forçada e contínua. Foram dispostas duas plantas em cada recipiente.

$$
\text { o desenvolvimento das plantas ocorreu entre }
$$

0 período de dezembro de 1980 e maio de 1981, dos quais o primeí ro mês (dezembro) foi em câmara de crescimento (condições de luz e temperaturas controladas), o restante (janeiro a maio) em casa de vegetação. Até aos 60 dias de idade, as plantas cresceram num volume de 3,0 litros de solução nutritiva, que foi renovada duas vezes. Daí em diante, foram transferidas pạ ra baldes contendo 10 litros de volume e que foram renovados a cada 30 dias. Efetuou-se o controle do pulgão, com duas apli cações de DIAZINON-60 E ( 2 ml/litro de $\mathrm{H}_{2} \mathrm{O}$ ).

\subsubsection{Delineamento Experimental}

Foi empregado o delineamento experimental intei ramente casualizado, contendo 5 tratamentos e 4 repetições e sendo consideradas 7 épocas de amostragens.

\subsubsection{Amostragens e Preparo}

Plantas inteiras foram colhidas em intervalos de quinze dias, durante o período de 90 a 180 dias, totalizando 7 épocas de amostragens. Em cada época foram amostrados os 5 tra tamentos $\left(\mathrm{K}_{1}, \mathrm{~K}_{2}, \mathrm{~K}_{3}, \mathrm{~K}_{4}\right.$ e $\left.\mathrm{K}_{5}\right)$ com 4 repetições sendo colhidas 20 plantas. O critério de seleção para escolha da planta a ser 
colhida foi baseado em caracteres visuais como sendo, altura e nümero de entrenös. A altura (h) foi determinada medindo-se desde o colo da raiz até a base da $3^{a}$. folha (ponto de formação da bainha da mesma folhal e o nūmero de entrenós, contados des de o colo da raiz até o entrenó envolvido pela bainha da $5^{a}$. fo Iha.

As folhas foram numeradas segundo descrito em MALA VOLTA et alii (1974), que considera o cartucho como folha no 10. As partes da planta, destinadas à determinação de atividade enzimätica (limbo foliar e bainha das folhas $3^{a}$ e

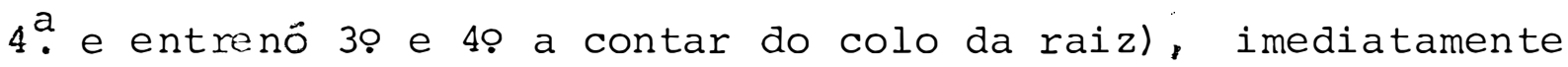
após a colheita de cada planta, foram destacadas e colocadas em baixa temperatura, utilizando-se caixa de isopor com gelo para as folhas e o colmo "inteiro" foi colocado em câmara fria. As raízes e demais folhas restantes foram submetidas a uma se cagem parcial na casa de vegetação e logo a seguir em estufa com circulação forçada de ar para secagem até pes̃o constante, sendó determinados a matéria seca produzida.

O material para análise enzimática, após concluí da cada amostragem, foi preparado conforme descrição abaixo.

a) Folhas e bainhas

Utilizou-se somente o terço médio do limbo foliar, destacando-se a nervura central. A seguir, estas partes consi deradas foram picotadas, acondicionadas em pacotes de aluminio e depois liofilizadas. 
A bainha foi destacada desprezando-se 2,0 cm de cá da extremidade e também picotada e liofilizada.

Todas as amostras, apös a liofilização, foram pe sadas e depois armazenadas em frascos dessecadores, sob vācuo em temperatura ao redor de $5^{\circ} \mathrm{C}$.

Durante todo este processamento as amostras fo ram sempre mantidas sob condições de baixa temperatura em cai xas de j.sopor contendo gelo.

b) Colmos

Dos colmos, utilizou-se o caldo extraído dos en trenōs 39 e 4\%, sendo que $10 \mathrm{~m}$ l foram congelados em ni.trogênio líquido e a seguir liofilizadas. O restante do caldo foj arma zenado em freezer a $-5^{\circ} \mathrm{C}$ para as demais análises.

O caldo Iıofilizac̈o foi armazenado sob condições idënticas às folhas. Na extração do caldo utilizou-se uma moen dá manual que foi lavada e secada após cada operação, sendo desprezados para cada amostra os primeiros $10 \mathrm{ml}$ do caldo ex traído.

O restante dos colmos, bem como o bagaço dos e.n tre nōs 39 e 4, foram colocados para secagem em estufa com cir culação forçada de ar até peso constante, para determinação da matéria seca. 


\subsubsection{Códigos Utilizados nas Amostras}

$$
C \text { = Colmo da cana de açucar (exceto os entrenós }
$$
30 e 49, usados para análise do caldol usados para determina ção da matéria seca.

$$
\text { I. } 39 \text { e } 49=\text { Entrenós n̊ } 39 \text { e } 4 \% \text {, contados a pari }
$$

tir do colo da raíz, cujo bagaço foi submetido à secagem atē peso constante, usados para determinação da matéria seca.

$$
\mathrm{R}=\text { Raiz da cana de açucar, usado para determina }
$$

ção da matéria seca.

$$
L=\text { Limbo foliar das folhas } 3^{a} \text { e } 4^{a} . \text {, que foram }
$$

liofilizadas.

$$
\text { B = Bainha das folhas } 3^{\mathrm{a}} \text { e } 4^{\mathrm{a}} \text {. que foram liofili }
$$

zadas .

OBS. - As amostras referentes ao tratamento $\mathrm{k}_{\mathrm{J}}$ não possuem va lores para C. Estas plantas apresentaram desenvolvimen to insuficiente, e o caldo para análise enzimática foi retirado do colmo inteiro, e não somente dos entre nós 30 e 4 \%.

3.2.6. Metodologia Analítica

3.2.6.1. Determinação de Açúcares Redutores (AR), Açücares Redutores Totais (ART) e Saca rose Estimada

Mediu-se $5 \mathrm{ml}$ do caldo extraído dos I. 30 e 
das canas amostradas, completando-se à $100 \mathrm{ml}$ com ägua destila da. Este caldo diluído (5\%) foi clarificado com uma mistura de $0,1 \mathrm{~g}$ de oxalato de södio mais $0,5 \mathrm{~g}$ de celite filtrado com pạ pel de filtro whatman no 1, segundo AMORIM \& ZAGO (1978).

No filtrado obtido foram dosados os teores de açūcares redutores e açūcares redutores totais pelo método co lorimētrico de NELSON (1944), utilizando-se um padrão de saca rose invertido a $50 \mathrm{\mu g} / \mathrm{ml}$, eretuando-se a leitura a $500 \mathrm{~nm}$, em espectrofotómetro BECKMAN DBG.

O teor de sacarose foi estimado pela diferença entre ART-AR, multiplicado por um fator 0,95 devido a molécula de àgua de hidrólise.

3.2.6.2. Dosagem Direta de Sacarose por Colori metria (PERCHERON, 1962)

O mëtodo se baseia na reação de desidrätação de hexoxes pela ação de ácidos fortes, formando hidroximetil-5-furfural, e que reage com o ácido tiobarbitūrico, formando um composto colorido, que apresenta pico de abosrção a 432,5 nm. Baseado neste mesmo princípio, estabeleceu-se um mëtodo para dosagem de frutose e de frutofuranosídeos.

Dentro dos limites de 0,02 a 0,2 umoles de fruto se a coloraçāo segue a lei de Lambert e Beer; sendo que a saca rose reage tambēm em concentraçōes molares iguais. A frutose livre é eliminada pelo aquecimento em banho-maria em ebulição, 
juntamente com uma base forte (NaOH) 5iN, segundo PRESSEY (.1969). Os açūcares rafinose e melizitose reagem como a sacarose, porém, existem em concentrações muito pequenas, em cana de açücar e podem, juntamente com a interferência da glí cose, serem corrigidas peja prova em branco.

Descrição do método:

1 - Medir l ml da solução aquosa (amostra conten do de 0,02 a 0,2 umoies de sacarose livre ou frutose).

2 - Adicionar l ml de solução aquosa de ácido tiobarbitúrico a $0,02 \mathrm{M}$.

3 - Adicionar $1 \mathrm{ml}$ de ácido clorídrico concentra do.

4 - Colocax a mistura em banho-maria fervente duㅡ rante exatamente 6 minutos.

5 - Resfriar imediatamente em ăgua fria corrente. 6 - Efetuar a leitura à $432,5 \mathrm{~nm}$.

A reta padrão obtida é apresentada na Figura 1.

3.2.6.3. Determinação da Atividade de Invertạ ses (E.C. 3.2.1.26) Ācida e Alcalina em Tecidos Vegetais

A metodologia empregada trata-se de uma adapta ção efetuada com base em inūmeras citaçōes considerando-se os principais fatores influentes na avaliação da atividade destas enzimas. Trata-se ainda de uma determinação em extrato bruto da atividade da fração solúvel intracelular, precipitável por 


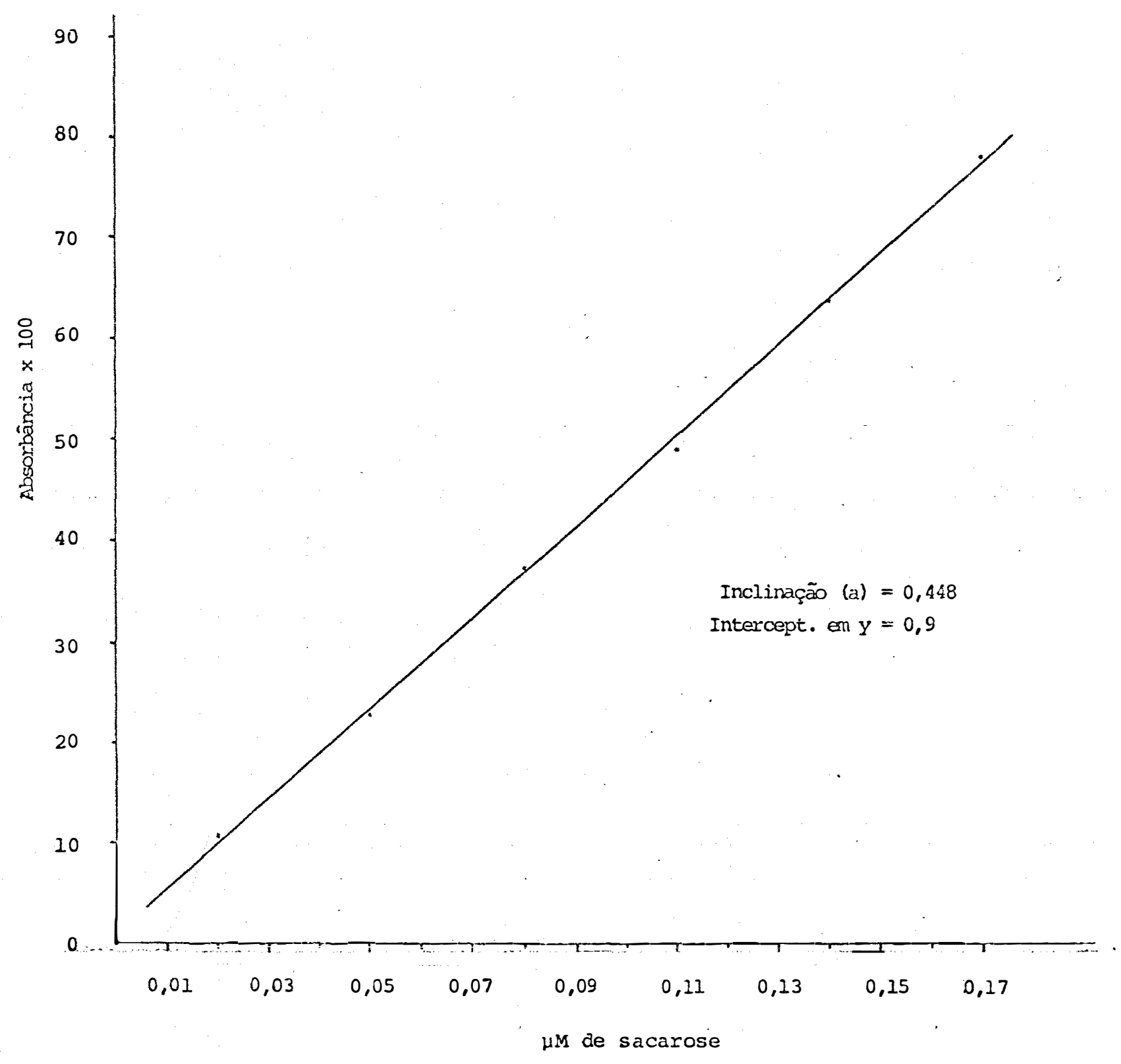

FIGURA 1 - Reta padrão obtida para dosagem direta de sacarose pelo método ào ācido tiobarbitúrico, adaptado de PERCHERON (1962). 
sulfato de amōnio até 60\% de saturação.

\section{a) Extração}

Pesou-se $500 \mathrm{mg}$ de material vegetal liofilizado, finamente txiturado, ao qual foi adjcionado $5 \mathrm{ml}$ de uma solu ção extratora, sendo homogeneizado por víbração durante 3 minu tos (testes preliminares nos permitiram determinar 0 tempo mais adequado de homogeneização). A seguix este material foi centrifugado a $18.000 \mathrm{~g}$ durante 20 minutos para separax o mate rial vegetal. A fração sobrenadante foi submetida a uma preci pi tação cơn l ml de solução saturadia de $\left(\mathrm{NH}_{4}\right)_{2} \mathrm{SO}_{4}$ sendo logo em seguida certrifugada a 15.000 g durante 20 minutos, para se paração da clorofila, que se precipita. o sobrenadante foi no vamente submetido a precipitação com $\left(\mathrm{NH}_{4}\right)_{2} \mathrm{SO}_{4}$ pxeviamente neu tralizado atē $60 \%$ de saturação, durante 12 horas em câmara fria $\mathrm{a} \pm 5^{\circ} \mathrm{C}$ (AIEXANDER, 1967 ).

o precipitado foi separado por centrifugaçäo a $15.000 \mathrm{~g}$ durante 10 minutos e a segui r retornado em 3 . ml de àgua destilada deionizada. o extrato assin obtido foi utijizado pa ra avaliar a atividaäe enzimäti.ca.

A solução extratora utilizadá foi baseada em BAI JAL et alii (1972) na qual omj.tiu-se o Triton $x-100$ e substi tuiu-se o tampão Tris-HCl por tampão NamPi - pH 7,2, vis to que segundo HATCH et aiii (1963) a enzima jnvertase é inibida por Tris e esta injibição aparentemente estä lígada ao pH. Esta so lução visa impedir a oxidação dos fenóis, muito intensa em te 
cidos vegetais de cana de açücar (SJ.ACK, 1966).

b) Incubação e Avaliação

Para inclibação, utilizou-se uma mistura baseada em HATCH \& GLAZIOU (1963) ligeiramente modificada, contendo $0,3 \mathrm{ml}$ de solução $0,2 \mathrm{M}$ de sacarose; $0,3 \mathrm{ml}$ de tampão foș Éto $0,05 \mathrm{M}, \mathrm{pH} 7,2$ ou $0,3 \mathrm{ml}$ de tampão citrato $0,05 \mathrm{M}, \mathrm{pH} 5,4 ; 0,05$ ml de tolueno e 0,l ml de extrato mais ägua destilada deioniza da para completar $1 \mathrm{ml}$. Esta solução foì incubada a $37^{\circ} \mathrm{C}$ duran te 1 hora, sendo paralizada pela adição de $1 \mathrm{ml}$ de etanol e aquecimento a $70^{\circ} \mathrm{C}$ durante 5 minutos. O àçücar redutor formado foi dosado segundo NEISON $(1944)$. Para cada amostra efetuou-se um teste em branco, contendo extrato enzimätico previamente desnaturado por aquecimento atē ebulição. Em uma alíquota do extrato enzimätico determinou-se ainda, a proteína total segun do MOKRASCH \& MC GILVERY (1956), expressando-se à atividade da enzima invertase em $\mathrm{mg}$ de sacarese invertida/mg de proteinas totais/hora.

3.2.6.4. Determinação da Atividade de Invertase Ácida e Alcalina em Caldo Liofilizado de Cana de Açucar

O caldo liofilizado foi diluído com l ml da mes ma soluçăo extratora utilizada para tecidos vegetais (evitar a oxidação dos fenōis) e a seguir dialisada contra ägua destila da a $\pm 5^{\circ} \mathrm{C}$ até abaixar a concentração de açūcares redutores. Pa 
ra a avaliação da atividade enzimática adotou-se o mesmo proce dimento utilizado para tecidos vegetais.

3.2.6.5. Determinação da Atividade de Sintetase de Sacarose (UDP glicose: D-frutose $2 \mathrm{gl}$ i cosiltransferase E.C. 2.4.1.13) em Te cidos Vegetais.

Utilizou-se para avaliação da enzimasintetase de sacarose (SS), o extrato obtido de modo semelhante ào utili zado para invertases.

a) Incubação e Avaliação

Preparou-se a mistura de reação, baseada ein PRES SEY (1969) ligeiramente modificada, contendo 5 pmoles de fruto se, 1,25 umoles de UDPG e 5 umoles de tampão Tris-HCl, pH 7,5. A esta mistura juntou-se $0,1 \mathrm{ml}$ de extrato enzimătico perfazen do um volume total de $0,3 \mathrm{ml}$. Esta mistura foi incubada a $37^{\circ} \mathrm{C}$ durante 1 hora, sendo logo a seguir adicionado 0,5 ml de $\mathrm{NaOH}$ 5N, e aquecido em banho maria em ebulição por 10 minutos. A seguir, completou-se o volume até $1 \mathrm{ml}$ corn água destilada deio nizada, dosando-se a sacarose formada pelo mètodo do ácido tiobarbitúrico (PERCHERON, 1962). Para cada amostra efetuou-se um 
teste em branco, com extrato enzimātico desnaturado por aqueci merıto até ebulição. A atividade da enzima ss foi expressa em uMol de sacarose sintetizada/mg proteína/hora de incubação.

3.2.6.6. Considerações sobre a Metodologia Enzi mātica Empregada

A não prevenção da oxidação dos fenóis durante o processo de extração protëico-enzimätica chega a provocar até 98\% de inibição na enzima ss e não inibem as invertases. Hsta inibição das ss pela oxidação dos fenỏis ë atribuída à reação de quinonas originadas pela oxidaçăo dos fenôis, com os grupos sulfidrilos da enzima (SLACK, 1966).

Esta enzima SS, tanto pode promover a sintese, como a degradação da sacarose (PRESSEY, 1969 e SHUKIA \& SANWAL, 1971). E a atividade da invertase poỏe ser mascaradá pela ação da SS quando se trabalha com extrato bruto, com inibiçäo das fenoloxi dases .

SHUKLA \& SANWAL (1971.) observaram em mandioca que a direção de sintese da ss è mãxima a $37^{\circ} \mathrm{C}$ e a quebra de sacarose é máxima a $45^{\circ} \mathrm{C}$.

Por outro lado, SAMPIETRO et alii (1980), sugere a presença de ligaçōes sulfidrílicas também nas invertases, devido a forte inibição provocada por agentes químicos como $I_{2}+\mathrm{Hg}^{2+}$ e p-cloromercuribenzoato (PCMB). Assim, a não preven ção na oxidação dos fenóis poderă tambēm inibir a atividade 
das invertases.

Portanto, no presente trabalho, o extrato protéi co enzimático para avaliação de SS e invertases foi obti:do, evitando-se, desde o início, a oxidação dos fenóis pelo método baseado em BAIJAL et alii (1972), e que tambëm reproduz melhor as condições reais no tecido in vivo.

Quanto à atividade de SS, CARDINI et alii (1955) não conseguiram obter resultados consistentes com esta enzima em extratos de folha de cana-de-açūcar, atribuindo como causa a interferência de invertases no ensaio. Mais tarde, observou-se que a adição de tris-HCl a 0,05M na mistura de reações eví ta a interferência das invertases, inibindo principalmente a invertase alcalina (HATCH et alii, 1963).

SLACK (1966) trabalhou com extrato bruto de Col] mo de cana de açũcar, utilizando 0 , lM tris-uCl na mistura de reações para avaliação da SS, para evitar a interferência de invertases.

\subsubsection{Determinação dos teores de $K, \mathrm{Na}, \mathrm{N}-\alpha$ $\mathrm{NH}_{2}{ }^{\prime}$ proteinas totais e $\mathrm{N}$-total em fo lhas $3^{\text {a }}$ e $4^{\text {a }}$ liofilizadas}

a) Os teores de $\mathrm{Na}^{+}$e $\mathrm{K}^{+}$foram dosados por espec trofotōmetria de absorção atōmica em extratos de folhas previä mente oxidados por uma mistura digestora composta de $\mathrm{H}_{2} \mathrm{SO}_{4} \mathrm{con}$ centrado $+\mathrm{H}_{2} \mathrm{O}_{2}+\mathrm{Se}+\mathrm{IiSO}_{4}$, conforme descrito em JøRGENSEN 
(1977)

b) O N-total foi determinado a partir do mesmo extrato obtido em (a) por colorimetria. O mëtodo baseia-se na reação do fenol-hipoclorito (reação de Berthelot), sendo o N$-\mathrm{NH}_{4}$ do extrato dosado como indofenol (PATTON \& CROUCH, 1977) sendo adaptado para dosagem de $\mathrm{N}$-total em extratos de tecidos vegetais obtidos pela digestão de Kjeldhal, por SMITH (1980).

c) A dosagem de $\mathrm{N}-\alpha^{\mathrm{NH}} 2$ foi efetuada pela extra ção em etanol a $80 \% \mathrm{v} / \mathrm{v}$ aquecido a $80^{\circ} \mathrm{C}$ durante 60 minutos, rea lizada em auas etapas sucessivas, utilizando em cada una, $5 \mathrm{ml}$ de etanol e centrifugado a $5000 \mathrm{~g}$ durante 10 minutos. Na fra ção sobrenadante, foi dosado $\circ \mathrm{N}-a \mathrm{NH}_{2}$ pelo reativo de ninhidri na ätivada con KCN 0,01 M, segundo KABAT \& MAYER (1967).

d) A anălise de proteína foi efetuada a partir do resj́duo sölido, obtido da extração de $\mathrm{N}-\alpha \mathrm{NH}_{2}{ }^{\prime}$ utili zámo-se NaGi I, ovi como extrator e duas etapas sucessivas de 5 . ml cada, aquecido a $90^{\circ} \mathrm{C}$ ciurante 60 minutos e centrifugado a $5000 \mathrm{~g}$ dixante 10 minutos. Neste extrato foi determinado _ as pxoteinas pelo reativo de cobre, segundo MOKRASCH \& MC GILVERY (1956). 


\section{RESULtadOS E DISCUSSÃO}

4.1. Desenvolvimento e Acümulo de Açücares

Durante o período de sej.s meses, as plantas apre sentaram um desenvolvimento contínuo sob condições bastante fa voráveis de luz e temperatura, conforme se observa nos dados das Tabelas 16 a 22, que apresentam as características morfoló gicas das plantas nas epocas de amostragens.

Com relação aos tratamertos $K_{1}, K_{2}, K_{3}, K_{4}$ e $K_{5}$, observou-se uma diferenciação mais evidente para as plantas com nível $\mathrm{K}_{1}$ de potässio, que apresentou un desenvolvimento bastan te reduzido, sem perfilhos. A concentração foliar de potässio nestas plantas deficientes oscilou em torno de $0,25 \%$ na maté ria seca liofilizada (folhas $\left.3^{a} \in 4^{a}\right)$, (Figura 2). Dentre to dos os tratamentos, $0 \mathrm{~K}_{1}$ foi o ünico que induziu ao aparecimen to de sintoma típico de deficiência de potássio, como sendo o avermeihamento da nervura principal, que se manifestou logo aos 60 dias. Os demais tratamentos apresentaram pequenas dife 

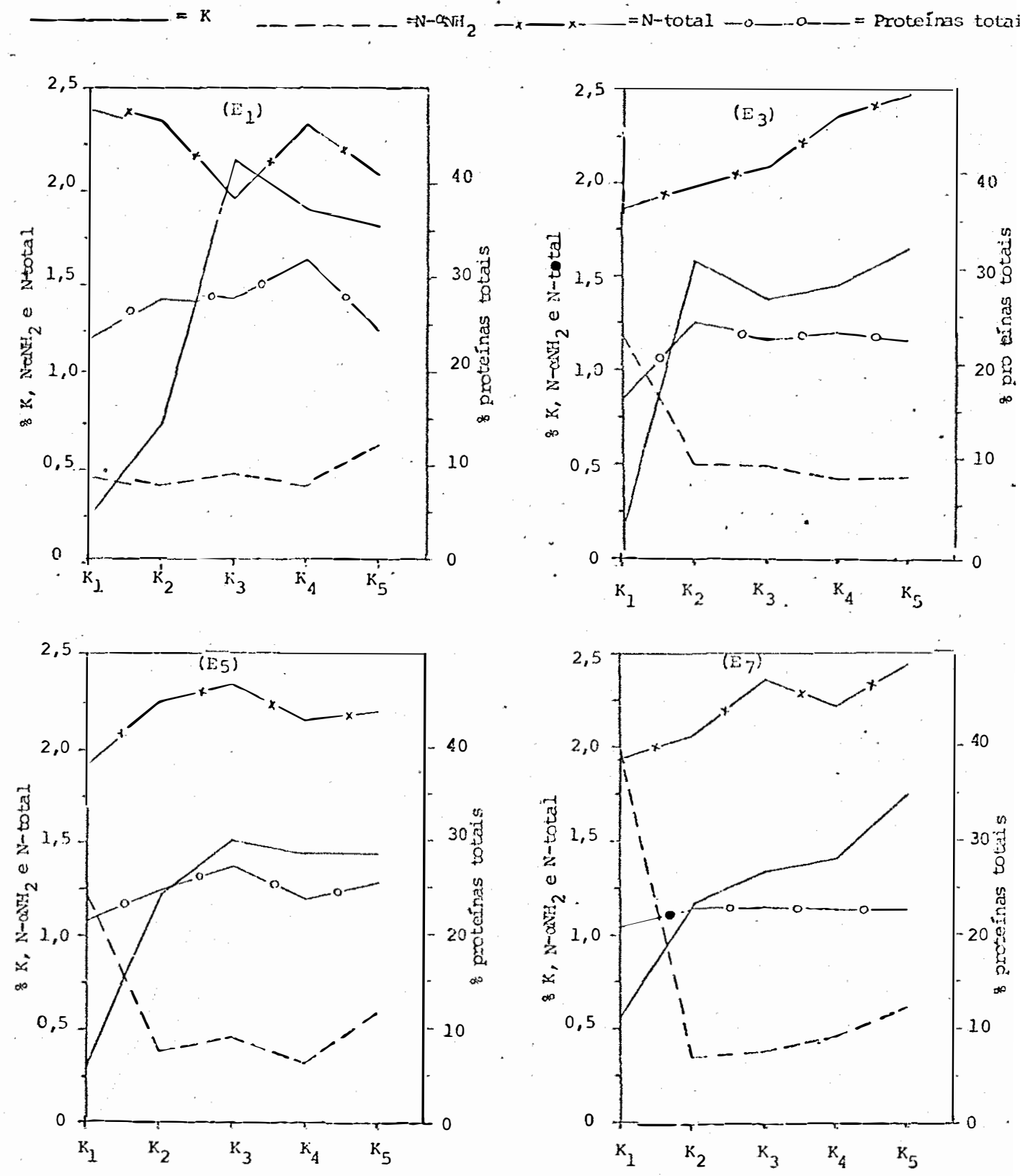

(8) - Expresso em g/1Jj de thatéria seca liøfilizada

FIGURA 2 - Concentrações de $\mathrm{K}, \mathrm{N}-\alpha \mathrm{NH}_{2}, \mathrm{~N}$-total e proteínas to tais encontradas em folhas $3^{a}$ e $4^{a}$. de cana-de - açú car CV. NA56-79 aOs $90\left(E_{1}\right), 120\left(E_{3}\right), 150\left(E_{5}\right)$ e $180\left(E_{7}\right)$ dias, considerando-se os diferentes trata mentos. 
renças entre si, o que pode ser avaliado pela produção total de matéria seca, apresentada na Figura 3. Todas estas plantas, apresentaram teores foliares de potássio acima de 1,0\%, sendo que segundo EPSTEIN (1972), a concentração de potássio conside rada adequada em plantas é de $1,0 \%$ na matéria seca.

As plantas de cana-de-açúcar cultivadas nas con dições descritas para o presente ensaio, até aos 6 meses : de idade, chegaram a acumular no caldo dos entrenós 39 e 49 amostrados, a proximadamente, $16 \%$ de sacarose. Exceto para o tratamento $\mathrm{K}_{1}$ que se diferenciou de modo bastante significativo dos demais tratamentos.

A Figura 4 mostra que a partir dos 90 dias de idade (ēpoca da primeira amostragem) o teor de sacarose nos vacúolos das células de armazenamento nos entrenós basais se encontrava em fase ir'cial de ascenção, continuando es te pro cesso durante os pröximos três meses, variando desde 1-2요 ini cial até $16-1.7 \%$ final. Para o tratamento $K_{1}$, conforme $j a ́$ men cionado na metodologia, extraiu-se o caldo de todo o colmo da planta, sendo que o baixo teor de sacarose no caldo extraído destas plantas deve ter sido, em parte, devido à diluição sofri da na extração.

A seleção dos entrenōs basais ( 39 e 4\%) visando estudar as alterações enzimäticas durante a fase inicial de biossíntese e acümulo de sacarose obteve resultados favoráveis, uma vez que de 1-2\% até 16-17\% de sacarose no caldo, obtidos desde os 90 aos 180 dias, respectivamente, representa a fase 


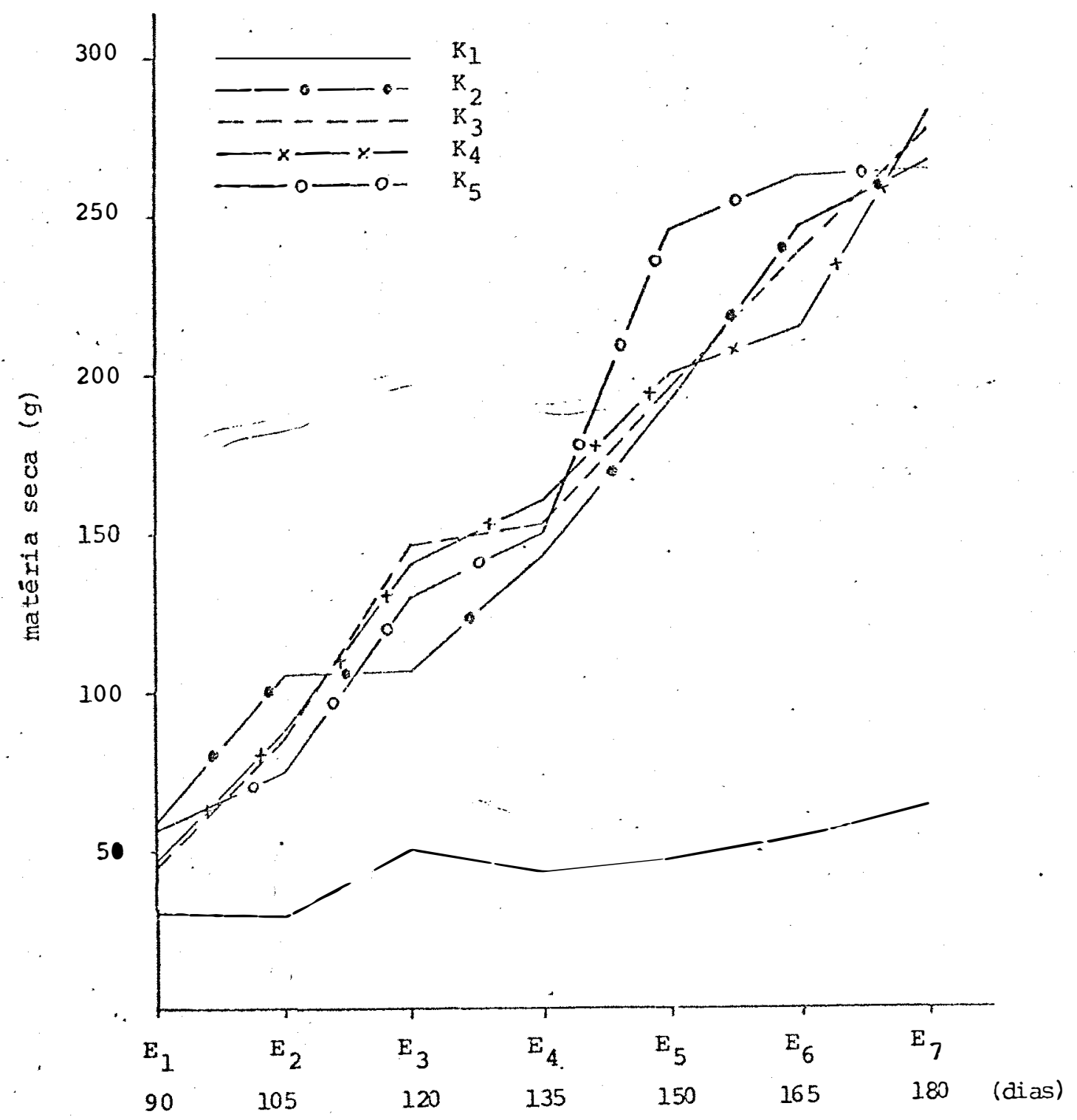

FIGURA 3 - Matéria seca total produzida, durante 90 à 180 dias, por cana-de-açücar cv. NA56-79, cultivada em solução nutritiva contendo 5 concentrações de potássio, desen volvidas em condiçōes de casa de vegetação. (Produ ção média em g/planta). 


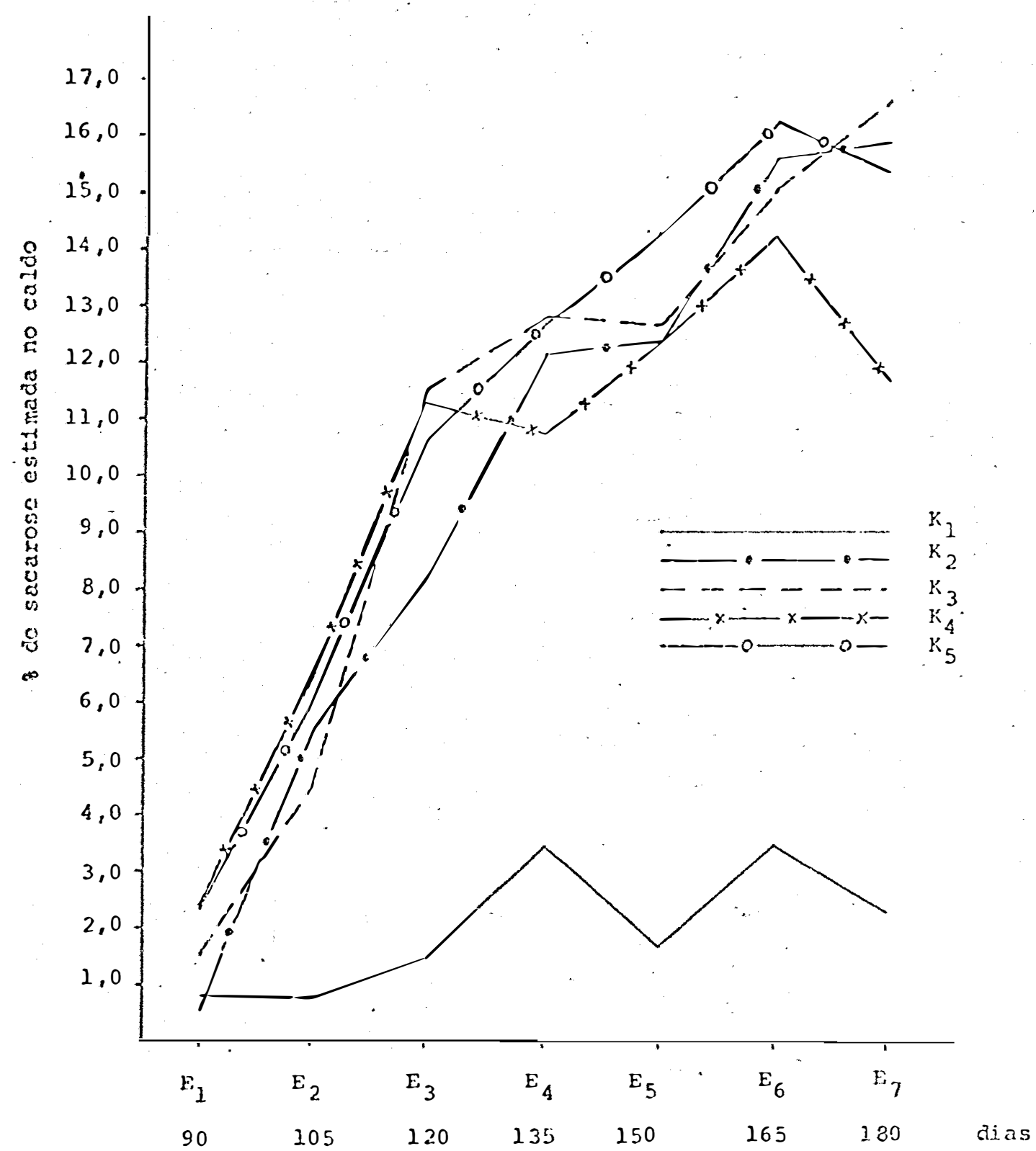

EIGURA 4 - Teor de sacarose acumulado, durante 90 a 180 dias, por cana-de-açūcar cv. NA56-79, cultivada em solu ção nutritiva contendo 5 concentrações de potāssio, desenvolvidas em condições de casa de vegetação. 
inicial e uma etapa já bastante avançada no processo de acúmü lo de sacarose no colmo. O teor médio de sacarose na cana-ảeaçúcar madura e normal é de 12,5\%, segundo BROWNE \& ZERBAN (1941) e no caldo este teor apresenta uma média de 17,0\% segun dO LEME JUNIOR \& BORGES (1963).

A evolução deste processo de acúmulo de sacarose no colmo pode ser observado tambëm pela Figura 5 que mostra a elevação no teor de ART desde aproximadamente 5,0\% até 17,0$-18,0 \% \mathrm{p} / \mathrm{v}$ e a redução do teor de $\mathrm{AR}$ de $4,0 \%$ até $0,2 \% \mathrm{p} / \mathrm{v}$.

Estes valores foram observados somente para os tratamentos $\mathrm{K}_{2}$ a $\mathrm{K}_{5}$, sendo que para as plantas deficientes em potássio $\left(K_{l}\right)$, os teores de AR e ART oscilaram entre 5,0 a $8,0 \% \mathrm{p} / \mathrm{v}$

A concentração de sacarose no caldo em relação aos níveis de potássio fornecido nas soluções nutritivas, indicam o tratamento $\mathrm{K}_{3}$, aos 6 meses de idade, como o que apresen tou maior acúmulo de sacarose, sendo muito arriscado, qualquer indicação com respeito à eficiência deste tratamento (Figura 4).

O tratamento $\mathrm{K}_{2}$ já apresentou uma queda na taxa de acümulo nos últimos quinze dias do sexto mês e os demais trata mentos, $\mathrm{K}_{4}$ e $\mathrm{K}_{5}$, apresentaram valores mäximos de acúmulo de sacarose aos 165 dias, diminuindo daí atē aos 180 dias, sendo esta queda mais acentuada para o tratamento $\mathrm{K}_{4}$ (Figura 4). E ta tendência apresentada por estes tratamentos, pode ser atri buída ao excesso de potássio, conforme se observa na Figura 2. Por outro lado, justamente no tratamento $\mathrm{K}_{5}$, que apresentou 0 

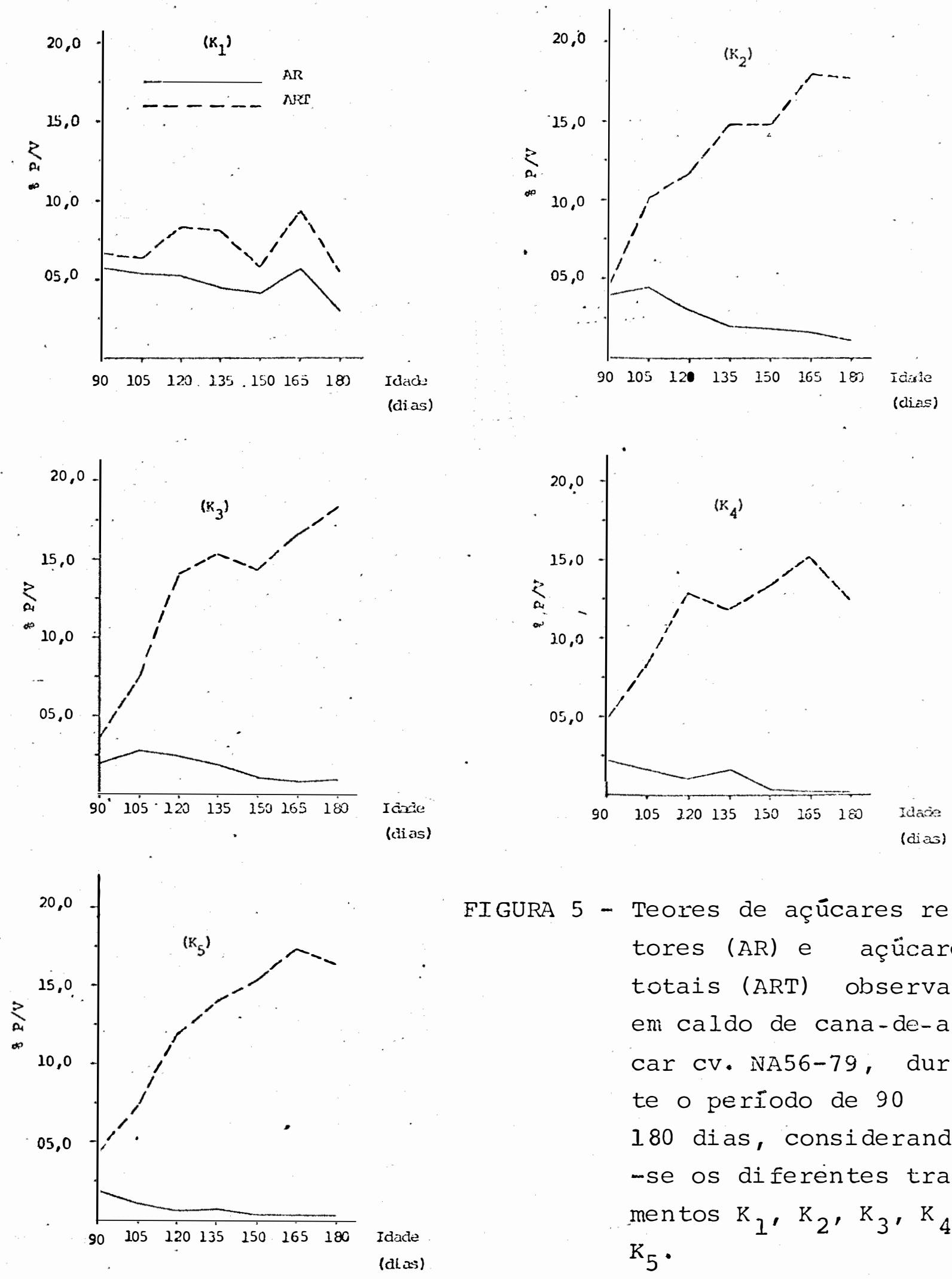

FIGURA 5 - Teores de açúcares redu tores (AR) e açücares totais (ART) observado en caldo de cana-de-açū car CV. NA56-79, duran te 0 período de 90 a 180 dias, considerando-se os diferentes trata mentos $\mathrm{K}_{1}, \mathrm{~K}_{2}, \mathrm{~K}_{3}, \mathrm{~K}_{4} \mathrm{e}$ $\mathrm{k}_{5} \cdot$ 
maior teor foliar de $K^{+}$, è que se observou aos 165 dias (.... $\left.E_{6}\right)$ um teor de $16,2 \%$ de sacarose no caldo, valor este que superou todos os demais tratamentos, inclusive $\circ \mathrm{K}_{3}$ (para esta época $\left.E_{6}\right)$. Assim, somente com os dados obtidos, fica muito dificil afirmar se os tratamentos $\mathrm{K}_{4}$ e $\mathrm{K}_{5}$ forneceram $\mathrm{K}^{+}$em níveis ex cessivos, capazes de provocar a queda na produção de sacarose no caldo.

Acredita-se que estas variações no acưmulo de sa carose no colmo seja normal e função, principalmente, da meto dologia analítica, uma vez que, segundo SIIVEIRA (1980), a re lação $\mathrm{K} / \mathrm{N}$ ótima apresentou valor de 0,94 , correspondendo a $2,33 \%$ de $\mathrm{K}^{+}$e $2,41 \%$ de $\mathrm{N}$-total nas folhas $3^{\mathrm{a}}$. e 4 ? aos 6 meses de idade, sendo tal combinação, responsävel pela maior concen tração e produção de sacarose e açücares redutores totais (ART) e acúmulo de matéria seca total na planta.

Deste modo, embora a produção de matéria seca do presente ensaio tenha sido, com a mesma idade, 3 vezes maior, o teor foliar para os tratamentos $\mathrm{K}_{4}$ e $\mathrm{K}_{5}$ foi $1,40 \%$ e 1,75\% pạ ra $\mathrm{K}^{+}$e 2,22 e 2,43\% para $\mathrm{N}$-total, respectivamente, o que, pro vavelmente, não chega a atingir nivveis prejudiciais a acúmulo de sacarose no colmo.

Porêm, de um modo geral, as condições aqui des critas foram as condições previstas para o presente ensaio, vis to que o principal objetivo era observar possíveis alterações metabólicas nas plantas acusadas pela variação na atividade das enzimas invertases àcida e alcalina e sintetase de sacarose 
em função do ion $K^{+}$, na fase inicial e durante o processo de acúmulo de sacarose nos colmos da cana de açúcar.

\subsection{Interações Potāssio/Atividade Enzimática}

A influência do ion $\mathrm{K}^{+}$sobre a biossintese de sa carose, conforme a Figura 4, pode ser evidenciada principalmen te no tratamento $K_{l}$, que se diferenciou dos demais. A análise do teor foliar de potássio (Figura 2), revelou valores em tor no de $0,25 \%$ para o tratamento $\mathrm{K}_{1^{\prime}}$ exceto para a época $\mathrm{E}_{7}$ (180 dias) cujo valor atingiu $\pm 0,6 \%$. Para os demais tratamentos observou-se um aumento evidente na concentração de potássío até $\circ \mathrm{K}_{3^{\prime}}$ de modo gexal. Os tratamentos $\mathrm{K}_{4}$ e $\mathrm{K}_{5}$ se diferencia ram muito pouco, sendo notável a necessidade de se efetuar tes tes de concentração de potássio entre os niveis $\mathrm{K}_{1}$ e $\mathrm{K}_{2}$ ' para se poder estudar melhor os possíveis efeitos da concentração de $\mathrm{K}^{+}$na atividade enzimática ligada ao processo de biossinte se e acúmulo de sacarose. A diferença em termos de crescimento das plantas do tratamento $k_{1}$ e os demais tratamentos é por de mais evidente, sugerindo que os efeitos observados quanto à biossintese e acúmulo de sacarose não são devidos somente ao ion $\mathrm{K}^{+}$, mas inclusive pela falha de absorção e metabolização de todos os demais nutrientes. Estas plantas se apresentaram bastante necrosadas, tanto na parte aérea como nas raízes.

A atividade de invertase ācida e alcalina em fo Ihas (limbo foliar) conforme a Figura 6, apresenta-se de modo 

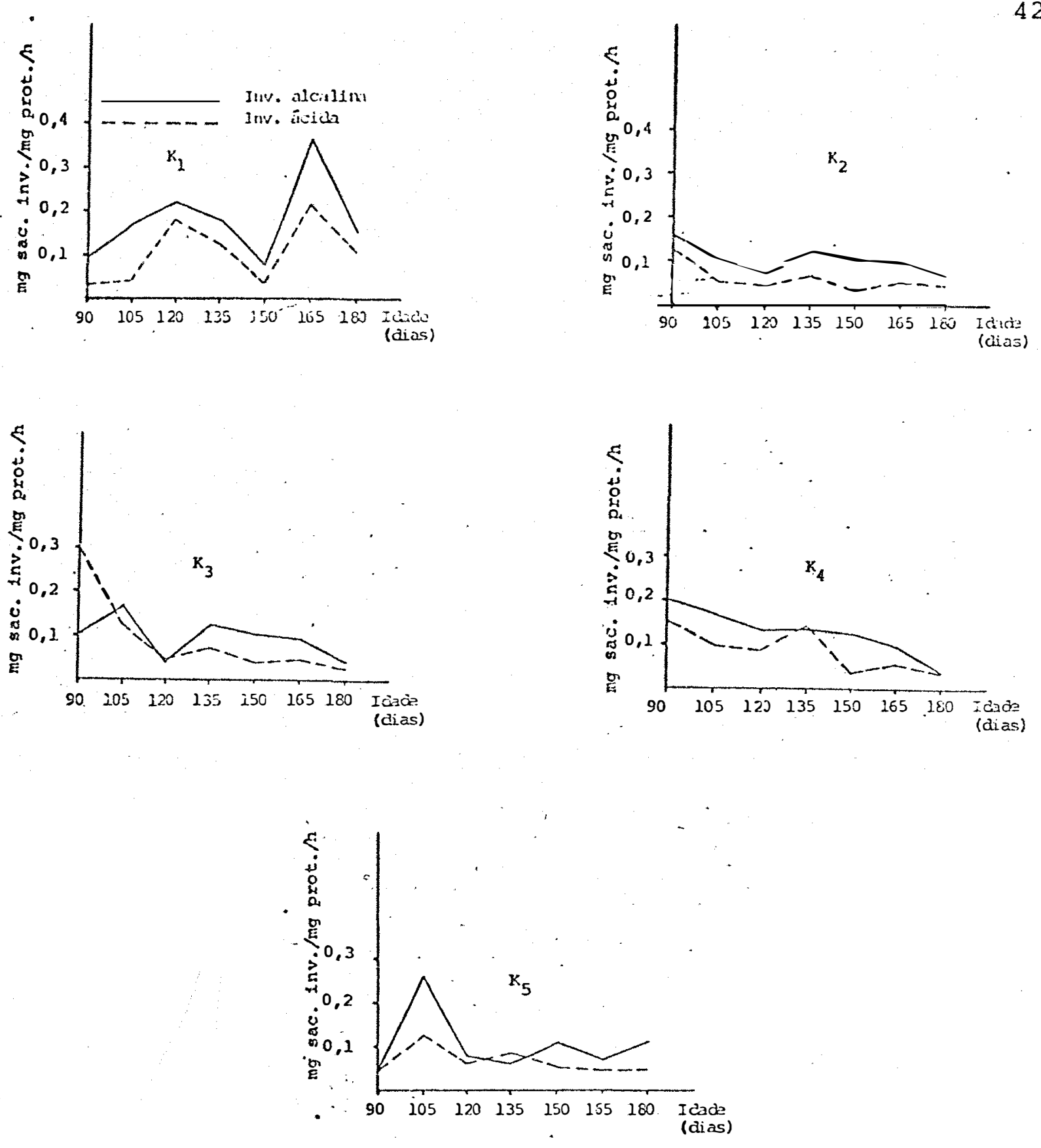

FIGURA 6 - Atividade de invertases àcida e alcalina observada em folhas de cana-de-açücar cv. NA56-79, durante o período de 90 a 180 dias, considerando-se os dife rentes tratamentos $\mathrm{K}_{1}, \mathrm{~K}_{2}, \mathrm{~K}_{3}, \mathrm{~K}_{4}$ e $\mathrm{K}_{5}$. 
quase constante durante o período considerado, principalmente para os tratamentos $\mathrm{K}_{2}, \mathrm{~K}_{3}, \mathrm{~K}_{4}$ e $\mathrm{K}_{5}$, sendo a atividade de in vertases ácida sempre inferior à alcalina. Este padrão quase constante na ativi aade destas enzimas, está bastante relaciona do com a função metabólica das folhas, qual seja a de produzir - fotossintato sacarose e utilizar uma fração para o metabolis mo de manutenção e crescimento da própria folha, cujos passos requerem a ação das invertases e de exportar a fração restan te para os demais órgãos em crescjmento (ALEXANDER, 1973).

Quanto ao tratamento $\mathrm{K}_{l}$ as plantas se apresenta ram com sintomas severos de deficiência de potássio, comprova dos pela produção de matêria seca, segundo a. Figura 3, e a ati vidade de invertases àcida e alcalina foliar, expressa em mg de sacarose invertida/mg proteína/hora, apresentaram variação na amplitude entre 0,03 e 0,35 mg de sacarose invertida, que foram maiores do que as apresentadas pelos demais tratamentos, cujas plantas não chegaram a manifestar sintomas visuais de deficiências de $K$. Tal situação pode ser explicada, uma vez que em plantas severamente afetadas por deficiēncia potāssica todo o processo de síntese é prejudicado e quase toda a sacaro se foliar que se apresenta em baixa concentração deve ser qua se totalmente invertida para atender a demanda metabólica das hexoses resultantes que serão utilizadas para o crescimento e manutenção, restando pouca sacarose para ser acumulada (Fi guras 4 e 6$)$. HART (1934) observou que os teores foliares de sacaro se em plantas deficientes em $\mathrm{K}^{+}$se apresentaram em torno de 
2,5\% contra 5,6\% na matéria seca, para plantas normais, cultiva da em solução nutritiva aos 7 meses de idade. SIIVEIRA (1980) obteve também em solução nutritiva p para plantas ligeiramente K-deficientes, aos 6 meses de idade, aproximadamente 0,36\% (na matéria seca contra 1,1\% para plantas normais. Deve ainda ser salientado que os valores de invertases obtidas em $\mathrm{K}_{l}$ foram mascarados pelo teor mais elevado de proteínas totais precipi tadas pelosulfato de amōnia junto com a proteína enzimática, que contribuiu para o abaixamento da atividade que foi expressa em termos de proteína no extrato. Segundo HART (1934), alta porcentagem de $\mathrm{N}^{-}$amino, proteínas e $\mathrm{N}$-total säo observa das em folhas de plantas de cana de açúcar conduzidas em solu ção nutritiva deficiente em potässio, o que é explicado, uma vez que ambas, síntese e translocação, são prejudicadas por de ficiēncia potässica. Todavia, segundo a Figura 2, o teor de proteínas totais nas folhas sempre foi menor para o trata mento $K_{1}$, o mesmo ocorrendo para o teor de $\mathrm{N}$-total, excetuan do-se para a època $E_{l}(90$ dias). Assim, a alta concentração de proteína, precipitada juntamente com a extração da proteína enzimática invertase sugere a necessidade de uma maior concentração molar desta enzima nos tecidos foliares das plan tas deficientes em potássio, uma vez que devido à baixa concen tração do substrato sacarose, exigirá uma maior coñcentração desta enzima, para atender à demanda energética, suprida pela oxidação de monossacarídeos (glicose e frutose), que, segundo GAYLER \& GLAZIOU (1972), são supridas principalmente da hidró 
lise da sacarose por ação das enzimas invertases.

$$
\text { Por outro lado, a referência de HART (1934) so }
$$

bre a alta porcentagem foliar de proteínas e N-total em plan tas deficientes em $\mathrm{K}^{+}$, deve ter sido em relação às demais par tes da planta.

Quanto ao teor de $\mathrm{N}$-amino realmente se apresen ta em concentrações bastante e levadas nas plantas deficientes em potássio $\left(K_{1}\right)$ (Figura 2), o que evidencia a impossibilidade destas plantas de apresentarem maior teor foliar de proteínas e N-total, do que plantas desenvolvidas em condições normais uma vez que o acūmulo de $\mathrm{N}$-aamino indica algum bloqueio na síntese de proteínas (IIEBHARDT, 1968 e CLARKSON \& HANSON,1980). Em relação ao alto teor de $\mathrm{N}$-total foliar (exce ção) apresentado pelas plantas do tratamento $K_{l}$ na época ( $E_{l}$ ) pode ser justificado uma vez que as mesmas tiveram o seu cres cimento prejudicado, conforme se observa na Figura 3, pela bai xa produção de matéria seca, induzindo a um acúmulo na poxcen tagem de $\mathrm{N}$-total nestas plantas até a época $E_{\mathcal{I}}$, uma vez que o nitrogênio $\left(\mathrm{NO}_{3}^{-}\right)$se encontrava disponível na solução nutritiva, não dependendo muito do volume radicular. A partir desta época $\left(E_{l}\right)$ até aos 6 meses $\left(E_{7}\right)$ a deficiência de $K^{+}$deve ter se mani festado mais intensamente, prejudicando a absorção dos nutrien tes da solução pelas raízes que se apresentaram parcialmente ne crosadas, devido à deficiēncia de potăssio. Segundo HART (1934) esta necrose é causada tanto pelo distūrbio na síntese protei ca, resultanto em protoplasma anormal nas células do feixe vas 
cular, como pelo acúmulo de ferro nos nódulos, provocando uma coagulação de proteínas do floema. Qualquer que seja a causa esta necrose compromete seriamente na translocação de carboi dratos e compostos nitrogenados.

Em bainhas foliares a atividade de invertases ácida e alcalina (Figura 7) se apresentaram em níveis bem pró ximos (dentro de cada tratamento) até aproximadamente aos 135 dias. A partir daí, se diferenciaram numa tendência para aumento de invertases alcalina e estabilização em valores baixos pạ ra invertases àcida.

Esta tendência estā de acordo com o observado por SAMPIETRO et alii (1980), que afirma a existência de um pa ralelismo entre a ativiaade enzimätica das invertases da baí nha foliar com a do colmo em crescimento, sendo observado em caldo extraído do coln por HATCH \& GIAZIOU (1963), que a ati vidade de invertases äcida diminui. à medida que se intensifica - acūmulo da sacarose no colmo, ocorrendo o inverso com a in vertase alcalina.

Os dados obtidos com relação à atividade de in vertases no caldo liofilizado extraído dos entrenós 30 e 49 (Fi gura 8) indicam uma queda na atividade das invertases ácida à medida que se intensifica o acúmulo de sacarose. Por outro la do, as invertases alcalina, também apresentaram diminuição na atividade, contrariando os dados obtidos por HATCH \& GLAZIOU (1963). Porém, deve se considerar que os citados autores utili zaram o caldo extraído de um mesmo colmo, considerando como va 

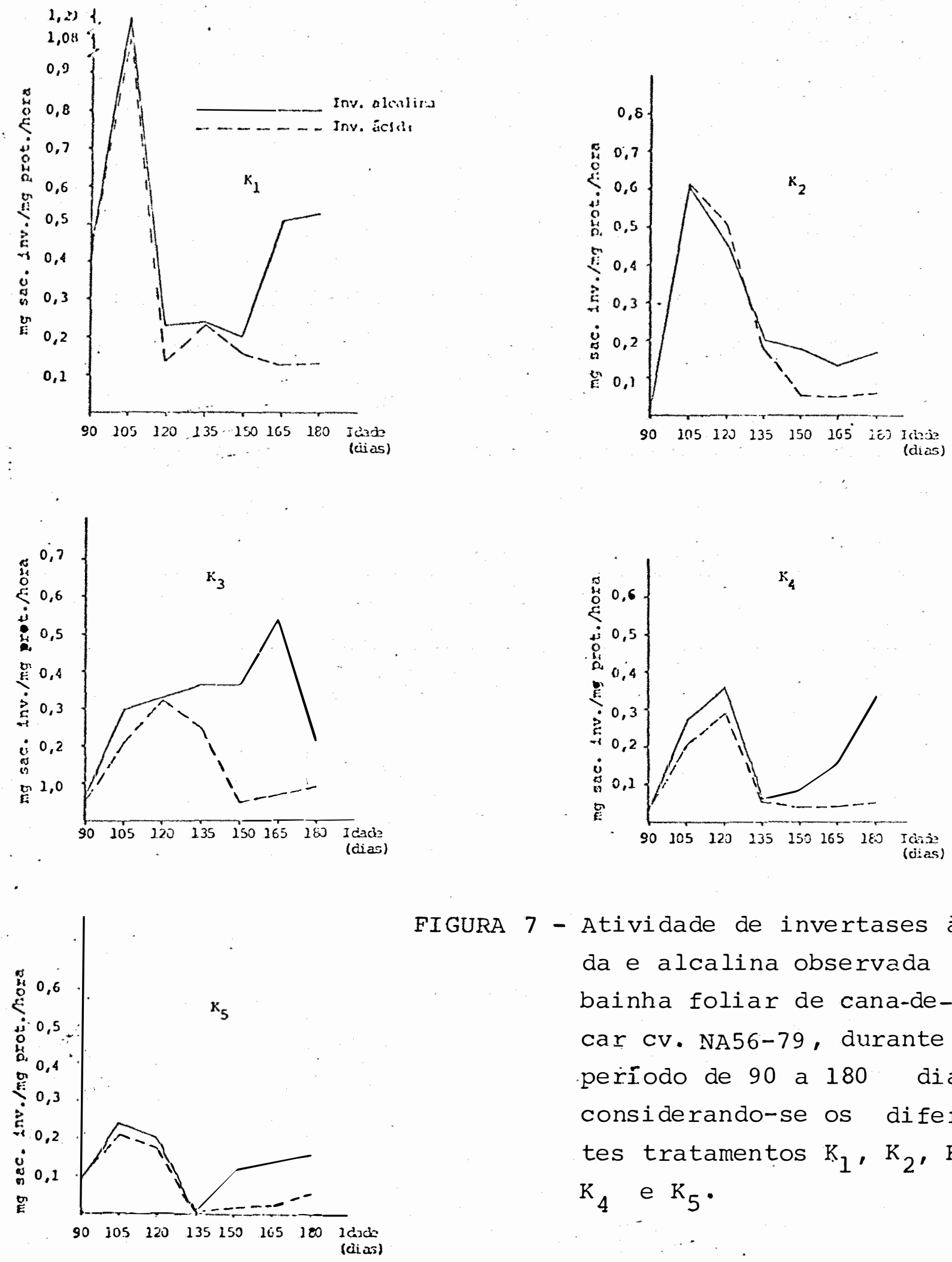

FIGURA 7 - Atividade de invertases äci da e alcalina observada em bainha foliar de cana-de-açú car CV. NA56-79, durante o período de 90 a 180 dias, considerando-se os diferen tes tratamentos $\mathrm{K}_{1}, \mathrm{~K}_{2}, \mathrm{~K}_{3}$, $\mathrm{K}_{4}$ e $\mathrm{K}_{5}$. 

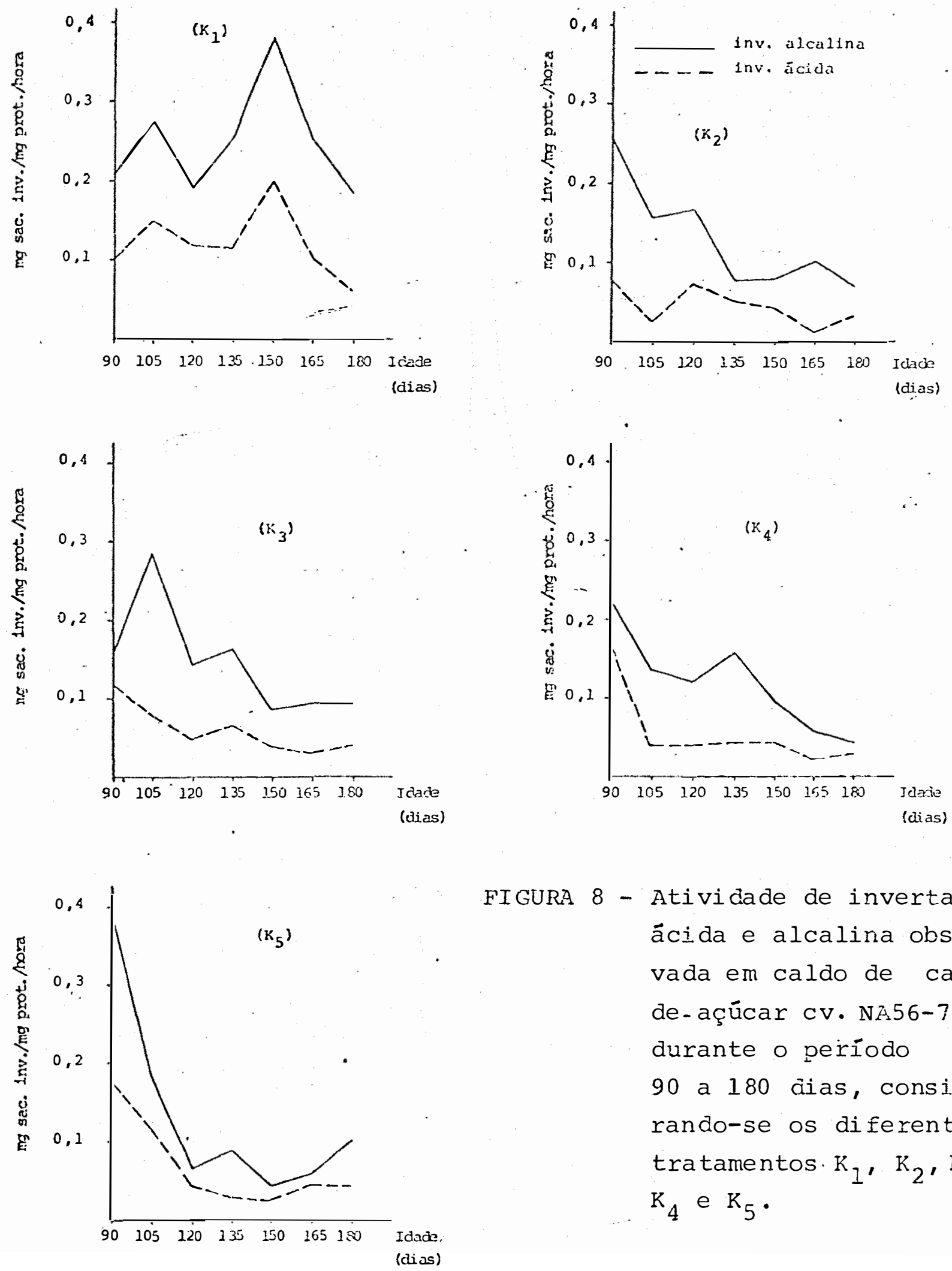

FIGURA 8 - Atividade de invertase ácida e alcalina obser vada em caldo de canade-açúcar CV. NA56-79, durante 0 período de 90 a 180 dias, conside rando-se os diferentes tratamentos. $\mathrm{K}_{1}, \mathrm{~K}_{2}, \mathrm{~K}_{3}$, $\mathrm{K}_{4}$ e $\mathrm{K}_{5}$. 
riações de estádios de maturação os entrenós basais mais adul tos, atē aos apicais. Alēm disto, a cana de açúcar utilizada contava com apenas 15 semanas de idade e com teor máximo de açúcares totais em torno de 5\% na matéria seca.

Os dados da Figura 8 mostram ainda que embora as invertases alcalinas tenham sofrido queda na atividade curante a maturação do colmo, elas se apresentaram sempre acima do ati vidade exibida pelas invertases ácidas, mostrando existir pre dominância das primeiras, durante as etapas de acūmulo de sa carose no colmo.

Esta diminuição na atividade de invertases ocox rida com o avanço. da maturação do colmo pode ser explicada ba seando-se nas observações feitas por HATCH \& GLAZIOU (1963) as quais indicaram que clurante a fase jovem as oélulas contêm grande quanti dade de invertases sŏlnveis, que tendem a diminuir quando ces sa à elongaçao celúlar. As células mais maduras contêm inverta ses ăcida da parede celular e invertases neutra insolüveis (HATCH \& GLAZIOU, 1963 e HAWKER \& HATCH, 1965).

Um outro fator que tambèm pode ter contribuido para esta diminuição é com respeito ao endurecimento normal dos tecidos do colmo quando atingem um estadio mais avançado de maturação, principalmente a casca celulósica que protege o colmo, dificultando a extração das enzimas celulares pelo prọ cesso normal de coleta de caldo, utilizando-se de moenda. Além do mais, nos tecidos jovens onde as células estão ainda em fa se de elongação, existe a atividade das invertases do espaço 
externo do tecido parenquimatoso como das invertases vacuolares, e que com a evolução do processo de acúmulo da sacarose nos va cuolos de armazenamento a invertase vacuolar deverá atingir va lores quase nulos, conforme observado por GAYLER \& GLAZIOU (1972).

Todas estas hipóteses podem ser ainda reforçadas quando se considera a Figura 8 , no tratamento $k_{1}$, no qual o cal do foi extraído do colmo inteiro das plantas amostradas, cuja casca não chegou a endurecer. A atividade de invertases ácida e alcalina, nestas plantas, diferenciou-se das demais, mostrando valores crescentes tanto de invertases àcida como alcalina até a época $E_{5}$ (150 dias), dininuindo daí até aos 180 dias. Nestas plantas cujo acúmulo de sacarose não pode ser evidenciado no perĩodo considerado (Figura 4), acredita-se que a extração ce lular das enzimas invertases, juntamente com o caldo, tenha si do mais eficiente.

Quanto à atividade de sacarose sintetase deter minada em extrato bruto de bainha foliar, observa-se na Figura 9 que não parece existir nenhuma tendência definida durante 0 processo de acúmulo de sacarose nos colmos mais adultos até a idade considerada. De um modo geral, apresenta pontos de ativi dade alta e baixa que se alternam com o tempo. A atividade des ta enzima, nas bainhas das folhas $3^{a}$. e $4^{a}$. analisadas, parece participar principalmente do movimento cíclico de açúcares gli cose e frutose para sacarose e vice-versa, relacionado segun do ALEXANDER (1973) com a manutenção de um equilíbrio (sistema 
5]. .
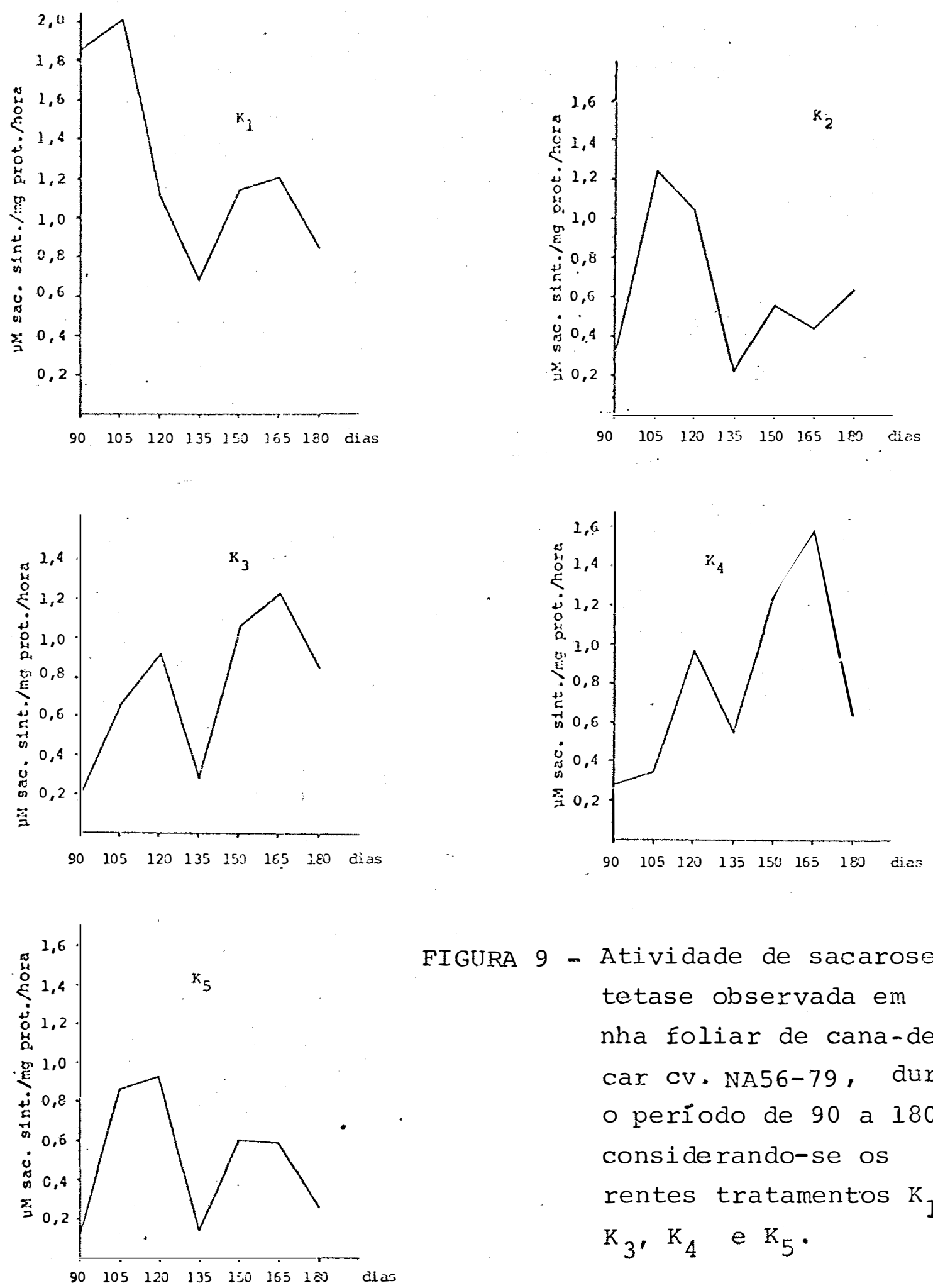

FIGURA 9 - Atividade de sacarose sin tetase observada em bai nha foliar de cana-de-açü car cV. NA56-79, durante o período de 90 a 180 dias considerando-se os dife rentes tratamentos $\mathrm{K}_{1}, \mathrm{~K}_{2}$ ' $K_{3}, K_{4}$ e $K_{5}$. 
tampãol para prevenir uma grande flutuação no suprimento : de açũcares no citoplasma e na prevenção de alteração excessiva no potencial osmótico vácuolar.

Para uma nelhox caracterizaçao bioquímica dos processos de acúmulo de sacarose nos colmos de cana de açücar, há necessidade, em trabalhos futuros, de se detalhar a ação das invertases na bainha foliar, ação esta, ao que tudo indica que é um dos pontos cruciais controlando a passagem do açücar formado no limbo foliar para o colmo, onde se acumula: limbo foliar, bainha e colmo, desse modo, são partes integrantes e interdependentes do sistema "fonte-reservatório" que ë a plan ta de cana de açücar. Por outro lado, o que se depreende dos resultados acui obtıdos é a necessidade de se efetuar ensaios com maior duração, que possibilitem o acompanhamento destas variāveis durante todo o ciclo da planta. 


\section{CONCLUSÕES}

Considerando-se as condições descritas parì o pre sente ensaio e em função dos resultados obtidos pode-se con cluir que:

a) A concentração de 0,1 n.mg $\mathrm{K}^{+} /$litro fornecida a solução nutritiva contendo todos os ảernais nutrientes em nívei considerado normal, induz a formação de plantas de cana de açú car com teor foliar (folhas $3^{a}$ e $4^{a}$ ) em torno de $0,25 \%$ de potás sio na matëria seca liofilizada, com redução drástica no cresci mento e com sintomas bastante acentuados de deficiência potăs sica.

b) Os entrenós 3: e 49 de cana de açūcar desenvol veu-se em solução nutritiva completa, acumularam até aos 6 me ses de idade, aproximadamente 16-17\% de sacarose no caldo, ex pressos em $\mathrm{p} / \mathrm{v}$.

c) Plantas de cana de açūcar severamente afetadas por deficiência potássica apresentaram teores elevados de $\mathrm{N}$ $-\alpha \mathrm{HN}_{2}$ evidenciando um bloqueio na etapa de biossintese protéi 
ca do metabolismo nitrogenado. Nestas mesmas plantas, a ativida de das enzimas invertases ácida e alcaìina foi relativamente maior, sugerindo, principalmente para as folhas, a existëncia de uma maior concentração molar destas enzimas para atender ao metabolismo energético de carboidratos.

d) As bainhas das folhas 3. e 4. de cana de açúcar apresentaram atividades com tendência para aumento de inverta ses alcalina e diminuição das invertases ācida à medida que a sacarose se acumulava nos entrenós maduros, sugerindo a existên cia de uma interação entre as atividades enzimáticas da bainha foliar e eventos bioquímicos do colmo em desenvolvimento. 
6. ITTERATURA CITADA

ALEXANDER, A.G. 1973. Sugar translocation and storage. In: ALEXAiNDER, A.G. Aut. Sugarcane Physiology. Ed. Elsevier S. Publ. Comp. Amsterdam. pp. 752.

ALEXANDER, A.G. 1957. Purification and electrophoretic beha vior of sugarcane invertases. J.Agric. Univ. P.R., 51 (1): $39-45$.

AMORIM, H.V. \& ZAGO, E.A. 1978. Análises para o controle da fermentação. ESALQ-USP. Depto. de Química. Apostila. 26 p.

BAIJAL, M.; SINGH, S.; SHUKLA, R.N. \& SANWAL, G.G. 1972. En zymes of banana plant. Optimum conditions for extraction. Phy to chem., 11:929-936.

BASSO, L.C. \& SMITH, T.A. 1974. Effects of mineral deficien cy on amine formation in higher plants. Phytochem., 13(6): 875-884.

BIEIESKI, R.L. 1960. The physiology of sugar cane. III - Ca racteristics of sugar uptake in silices of mature and imma ture storage tissue. Aust。 J。Biol. Sci., 13(3):203-220. 
BROWNE, C.A. \& ZERBAN, E.W. 1941. Physical and chemical me thods of sugar analysis. $3^{\text {rd }}$ ed. New York. Wiley. 1353p. CARDINI, C.E.; LELOIR, L.E. \& CHIRIBOGA, J. 1955. The bio synthesis of sucrose. JoBiol. Chem., 214:149-155.

CLARKSOIN, D.T. \& HANSON, J.B. 1980. The mineral nutrition of higher plants. Ann. Rev。Plant Physiol., 31:239-98.

CROCOMO, O.J.; BASSO, L.C. \& BRASIL, O.G. 1970. Formation of $\mathrm{N}$-carbamyl putresine from citrulline in sesamum. Phytoshem, $\underline{9}: 1487-89$.

EPSTEIN, E. Nutriçāo mineral das plantas. Princípios e Pers pectivas. Trad. E. MALAVOLTA. Ed. USP. 34 lp. 1975. EVANS, H.J. \& SORGER, G. 1966. Role of mineral elements with emphasis on the univalent cátions. Ann. Rev. Plant Physiol, $17: 47-76$.

EVANS, J.H. \& WILDES, R.A. 1971. Potassium and its role in enzyme activation. In: $8^{\text {th }}$ Colzoquium International Potash Instituie, Uppsala/Sweden. Ed. International Potash Insti tute Berne Swetzarland. $244 \mathrm{pp}$.

FRYDMAN, R.B. \& HASSID, W.Z. 1963. Byosynthesis of sucrose with sugarcane leaf preparations. Nature, 199:382-383. GAYLER, K.R. \& GLAZIOU, K.T. 1969. Plant enzyme synthesis: Hormonal regulation of invertase and peroxidase synthesis in sugarcane. Planta, 84:185-194.

GAYLER, K.R. \& GLAZIOU, K.T. 1972, Fhysiological functions of acid and neutral invertases in growth and sugar storage in sugarcane. Physiol. Plant., 27:25-31. 
GLAZIOU, K.T. 1960. Accumulation \& transformation of sugar in sugar cane stalks. Plant Physiol., 35:895-90l.

GLAZIOU; K.T. 1961. Accumulation \& transformation of sugars in stalks of sugar cane. Origin of glucose \& frutose in the inner space. Plant Physiol., 36:175-179.

GLAZIOU, K.T. 1962. Accumulation \& transformation of sugars in sugar cane stalks: Mechanism of inversion of sucrose in the inner space. Nature, 193:1100.

HAEDER, H.E. \& MENGEL, K. 1974. Effect os nutrition on $\mathrm{CO}_{2}$ assimilation and grain filling of wheat during the reproduc tive stage. In: Proc. $7^{\text {th }}$ Intern. Collog. on Plant Analy sis and Fertilizer Problems, Hannover. p. 135-145. HAQ, S. \& HASSID, W.Z. 1965. Biosynthesis of sucrose phospha te with sugar cane leaf chloroplasts. Plant Physior., 40 : $591-594$.

HARTT, C.E. 1934. Some effects of potassiun upon the amounts of protein and amino forms of nitrogen, sugars and enzyme activity of sugar cane. Plant Physiol., 9:453-490.

HARTT, C.E. 1969. Effect of potassium deficiency upon trans location of ${ }^{14} \mathrm{C}$ in attached blades and entire plants of su garcane. Plant Dhysiol., 44:1461-1469.

HARTT, C.E. 1970. Effect of potassium deficiency upon trans location of ${ }^{14} \mathrm{C}$ in detached blades of sugarcane. P Lant Phy. siol., $45: 569-571$.

HASSID, W.Z. \& PUTMAN, E.W. 1950. Transformation of sugars in plants. Ann. Rev. Plant Physiol., I: 109-124. 
HASSID, W.Z. \& DOUDOROF, M. 1950. Synthesis of disacharides with bacterial enzymes. Adv。 Enzymol., 10:123-143.

HATCH, M.D.; SACHER, J.A. \& GLAZIOU, K.T. 1963. Sugar accumu lation cycle in sugar cane. I - Studies on enzymes of the cycle. Plant Physiol., 38:338-343.

HATCH, M.D. \& GLAZIOU, K.T. 1.963. Sugar accumulation cycle in sugar cane. II - Relationship of invertase activity to sugar content \& growth rate in storage tissue of plants grown in controlled enviroments. Plant Physiol., 38: 344-348 .

HAWKER, J.S. \& HATCH, M.D. 1965. Mechanism of sugar storage by mature stem tissue of sugarcane. Physiol. Plant, 18: $444-453$.

HOAGLAND, D.R. \& ARNON, D.I. 1950. The water culture method for growing plants wi.thout soil. Calif. Agr. Exp. Sta., Ca lifpornia, Circ. 347.

JØRGENSEN, S.S. 1977. Guia analítico. Metodologia utilizada para anālıse química de rotina. Centro de Energia Nuclear. na Agricultura. CENA, Piracicaba, SP. $23 \mathrm{p}$.

KABA'T, A.E. \& MAYER, M.M. 1967. Ninhydrin method for primary amino acids. In: Experimental Immunochemistry, Charles \& Thomas. Pub. USA. p.56l-563.

LEME JUNIOR, J. \& BORGES, J.M. 1965. Açūcar de cana. Viçosa, Universidade Rural de Minas Gerais. 328p. LIEBHARDT, W.C. 1968. Effect of potassium on carbohydrate me tabolism and translocation. In: KILMER, V.J. Aut. The role of 
Potassium in Agriculture. cap. 7:147-164. Ed. USA, 509p. MALAVOLTA, E.; HAAG, H.P.; MELIO, F.A.F. \& BRASIL SOBRINHO, M.O.C. 1974. Nutrição mineral e ñdubação de Plantas Culti vadas. Ed. Livraria Pioneira, São Paulo, SP. 727 p.

MENGEL, K. \& VIRO, M. 1974. Effect of potassium supplyy on the transport of photosyntates to the fruits of tomatoes (Lycopersicon esculentum). Physiol. Plant, 30:295--300. MENGEL, K. \& KIRKBY, E.A. 1978. Principles of plant nutriti on. International Potash Institute Berne, Switzerland. 593 p.

MOKRASCH, L.C. \& MC GILVERY, R.W. 1956. Purification and pro perties of fructose 1,6-diphosphate. J. Biol. Chem., 22l: 909-917.

NELSON, N. 1944. A photometric adaptation of the Somogy me thod for the determination of glicose. J. Biol. Chem. 153: $375-380$.

OZBUN, J.L.; VOLK, R.S. \& JACKSON, W.A. 1965. Effect of po tassium deficiency on photosynthesis, respiration and the utilization of photosynthetic reductant by immature bean leaves. Crop. Sci., $\underline{5}: 69-74$.

PATTON, C.J. \& CROUCH, S.R. 1977. Spectrophotometric and $\mathrm{ki}$ netics investigation of the Berthelot Reaction for the de termination of ammonia. Anal. Chem., $\underline{49}(3): 464-469$. PERCHERON, F. 1962. Dosage colorimetrique du fructose et des fructofuranosides par lácide thiobarbiturique. Compt. Rend., 255: $2521-22$. 
PELUGER, R. \& MENGEL, K. 1972, The photochemical activity of chloroplasts abtained from plants with a different potas sium nutrition. Elant and Soiz, 36:417-425.

PRADO, F.E.; SAMPIETRO, A.R. \& VATTUONE, M.A. 1979 . Ammonium heptamolybdate, an inhibitor of plant invertases.Phytochem., 18: $1799-1802$.

PRESSEY, R. \& SHAW, R. 1966. Effect of temperature on inver tase, invertase inhibitor and sugars in potato tubers. Plont Physiol., 41:1657-61.

PRESSEY, R. 1969. Potato sucrose synthetase: purification, properties, and changes in activity associated with matura tion. Plant Physiol., 44:759-764.

RAINS, D.W. 1976. Mineral metabolism. In: J. BONNER \& J.E. VARNER. Plant Biochemistry. 3: ed. New York : Acacemic, $925 \mathrm{pp} . \quad \mathrm{pp} .633-81$.

SAMEIETRO, A.R.; VATTUONE, M.A. \& PRADO, F.E. 1980. A regula tory invertase from sugar cane leaf-sheaths. Phy tochem, $19: 1637-1642$.

SHUKLA, R.N. \& SANWAL, G.G. 1971. Studies on UDP-glucose, D-fructose-2-giucosyl transferase from Tapioca tubers. Arch. Biochem. Biophys., 142:303--309.

SILVA, W.M. 1976. Termoterapia em gemas isoladas assegura o controle do raquitismo. Boletim Técnico Copersucar, (1):10$-13$.

SILVEIRA, J.A.G. 1980. Aspectos bioquímicos e fisiológicos da relação K/N em cana de açūcar (Saccharum spp) cv. NA-5679 
cultivada em solução nutritiva. Piraci Gaba, ESALQ/USP. 127 p. (Dissertação de Mestrado).

SLABNIK, E.; FRYDMAN, R.B. \& CARDINI, C.E. 1968. Some prope $\underline{\text {. }}$ ties of potato tuber UDPG: D-fructose 2-glucosyltransferase (E.C. 2.4.1.14) and UDPG: D-fructose 6-posphate 2-glucosy I transferase (E.C.2.4.1.13). Plant Physiol.,.43:1063-1068. SLACK, C.R. 1966. Inhibition of UDP-glucose: D-frutose 2-glucosyltransferase from sugar cane stem tissue by phenol oxidation products. Phytochem., 5:397-403.

SMITH, V.R. A phenol-hypochlorite manual determination of am monium-nitrogen in kjeldahl digest of plant tissue. Commun. in Soil Sci. and Plant Analysis, $11(7): 709-722$.

SUELTER, C.H. 1970. Enzynes activated by monovalent cations. Science, 148:789-95.

SUELTER, C.H. 1974. Monovalent cations in enzyme - catalyzed reaction. In: SIGEL, H. Metal Ions in Bü.ological Systeins. ed. 1973-1978, vol. 1-7, 3: 201-51.

THOMAS, G.W.; COLEMAN, N.T. \& JACKSON, W.A. 1959. Influence of magnesium potassium and nitrogen nutrition on phosphoe nolpyruvate-stimulated carbon dioxide fixation. Agron. J., 51:591-593. 
62.

A $\quad$ P $\quad N \quad D \quad I \quad C \quad E$ 
TABELA 1 - Matéria seca produziảa aos 90 dias, para cana-de-açü car Saccharum spp cv. NA56-79, cultivadas em solução nutritiva contendo 5 concentraçōes de potássio, de senvolvidas em condições de casa de vegetação.

\begin{tabular}{|c|c|c|c|c|c|c|c|c|c|}
\hline \multirow{2}{*}{ Tratzrento } & \multirow{2}{*}{ Anostra } & \multicolumn{3}{|c|}{ Colmo $(g)$} & \multicolumn{3}{|c|}{ Folhas (g) } & \multirow{2}{*}{ Raiz } & \multirow{2}{*}{ Total } \\
\hline & & I $3 \in 4 R$ & $c$ & & L & B & Rest. & & \\
\hline . & $31-1$ & 2,85 & -- & & 1,35 & 1,58 & 13,34 & 5,84 & 24,96 \\
\hline \multirow{3}{*}{$x_{1}$} & $35-2$ & 2,18 & - & & 1.03 & 1,35 & 12,27 & 5,91 & 22,74 \\
\hline & $8-2$ & 4,72 & -- & & 1,04 & 3,04 & 18,70 & 8,44 & 33,87 \\
\hline & $8-1$ & 6,14 & -- & & 1,38 & 1,53 & 21,85 & 7,85 & 38,75 \\
\hline \multirow[t]{2}{*}{ Médía } & & & & & & & & & 30,08 \\
\hline & $26-1$ & 5,26 & 8,75 & & $-1,31$ & 1,39 & 23,98 . & 14,55 & 53,85 \\
\hline \multirow{3}{*}{$x_{2}$} & $26-2$ & 6,37 & 14,27 & & $\quad 1,38$ & 1,85 & 29,03 & 14,58 & 67,48 \\
\hline & $19-1$ & 6,26 & 10,68 & & 1,23 & 1,80 & 28,39 & 14,86 & 63,22 \\
\hline & $19-2$ & 4,32 & 8,76 & & 1,51 & 1,63 & 23,70 & $: 4,42$ & $54,3: i$ \\
\hline \multirow[t]{2}{*}{ Média } & & $\cdot$ & & & & & & & 59,72 \\
\hline & $49-1$ & 3,53 & $5,3 \bullet$ & & 1,27 & 1.41 & 16,60 & 8,81 & 35,92 \\
\hline \multirow{3}{*}{$x_{3}$} & $49-2$ & 5,20 & 7,33 & & 1,25 & 1,39 & 22,37 & 10,69 & 48,23 \\
\hline & $56-1$ & $4,13$. & 6,75 & & 1,31 & 1.47 & 20,41 & 10,74 & 44,81 \\
\hline & $56-2$ & 4,18 & 5,77 & & 3,28 & 1,57 & 22,61 & 12,75 & 48,16 \\
\hline \multirow[t]{2}{*}{ Média } & & & & & & & & & 44,53 \\
\hline & $40-1$ & 4,76 & 6,46 & & 1,59 & 1,52 & 20,00 & 10,92 & 44,25 \\
\hline \multirow{3}{*}{$k_{4}$} & $40-2$ & 2,93 & 4,35 & & 1,31 & 1,52 & 18,10 & 9,91 & 38,12 \\
\hline & $62-1$ & 5,83 & 8,72 & & 1.44 & 2,06 & $16,99^{\circ}$ & 15,03 & 50.07 \\
\hline & $62-2$ & 5,03 & 10,32 & $\cdots$ & 1.55 & 1.81 & 17,86 & 14,40 & 51,99 \\
\hline Médía & & & & & & & & & 46,10 \\
\hline . & $53-1$ & 5,97 & 11,02 & & 1,66 & 1,96 & 32,56 & 14,11 & 67,33 \\
\hline \multirow{3}{*}{$x_{5}$} & $53-2$ & 3,20 & 5,41 & & 1,18 & 2,58 & 18,22 & 11,43 & 41,02 \\
\hline & $63-1$ & 5,02 & 17,68 & & 1,77 & 2,10 & 33,81 & 13,18 & 73,56 \\
\hline & $63-2$ & 3.25 & 7,31 & & 1,18 & 1,81 & 19.05 & 10,89 & 43,49 \\
\hline Média & & & & & & & & & 56.35 \\
\hline
\end{tabular}


TABELA 2 - Matéria seca produzida aos 105 dias, por cana-de-açü câr Saccharum spp cv. NA56-79, cultivadas em solução nutritiva contendo 5 concentrações de potâssio, de senvolvidas em condiçōes de casa de vegetação.

\begin{tabular}{|c|c|c|c|c|c|c|c|c|c|c|}
\hline \multirow{2}{*}{ Tratamento } & \multirow{2}{*}{ Anostra } & \multicolumn{3}{|c|}{ Colmo (g) } & & \multicolumn{3}{|c|}{ Folhas (9) } & \multirow{2}{*}{ Radz } & \multirow{2}{*}{ Total } \\
\hline & & I 38 e 48 & & c & & L & B & Rest. & & \\
\hline \multirow{4}{*}{$x_{1}$} & $17 \div 1$ & 4,65 & & - & & 1,66 & 1,05 & 18,29 & 6,25 & 31,90 \\
\hline & $47-2$ & 2,57 & & - & & 1,60 & 0,71 & 23,95 & 5,18 & 24,01 \\
\hline & $42-1$ & 5,25 & & - & & 1,85 & 0,91 & 16,31 & 9,17 & 32,99 \\
\hline & $42-2$ & 4,59 & & - & & 1,44 & 0,90 & 13,62 & 6,21 & 26,76 \\
\hline \multirow[t]{2}{*}{ Méd1a } & & & $\cdots$ & & & & & & & 28,91 \\
\hline & $43-1$ & 8,16 & & 18,23 & & 1,62 & 1,72 & 40,36 & 20,11 . & S0, 20 \\
\hline \multirow{3}{*}{$x_{2}$} & $43-2$ & 9,59 & & 22,36 & & 2,43 & 2,11 & 42,06 & 21,69 & 100,24 \\
\hline & $50-1$ & 11,48 & & 30,60 & & 2,62 & 2,35 & 43,25 & 21,89 & 112,19 \\
\hline & $50-2$ & 10,51 & & 35,03 & & 2,70 & 2,44 & 48,30 & 22,28 & 121,26 \\
\hline \multirow[t]{2}{*}{ Médta } & & ; & & & & & & & & 105,72 \\
\hline & $44-1$ & $, 5,56$ & & 17,22 & & 2,51 & 2,31 & 23,75 & 17,30 & 68,65 \\
\hline \multirow[t]{3}{*}{$x_{3}$} & $44-2$ & 8,35 & & 24,15 & & 2,70 & 2,35 & 39,07 & 18,41 & 95,03 \\
\hline & $51-1$ & 7,35 & & 14,51 & & 2,09 & 1,91 & 34,23 & 14,25 & 74,34 \\
\hline & $68-1$ & 13,23 & & 27,10 & & 2,23 & 2,64 & 42,46 & 17,69 & 105,85 \\
\hline \multirow[t]{2}{*}{ Mécila } & & & & & & & & & & 85,97 \\
\hline & $28-1$ & 9,63 & & 27,78 & & 2,72 & 2,43 & 42,57 & 18,10 & 103,23 \\
\hline \multirow[t]{3}{*}{$x_{4}$} & $28-2$ & 10,71 & & 24,32 & . & 3,07 & $1,93$. & 42,12 & 19,74 & 101,33 \\
\hline & $45-1$ & 5,69 & & 15,52 & & 2,27 & 2,07 & 29,72 & 24,28 & 69,65 \\
\hline & $52-1$ & $8,8.5$ & & $15,50^{\circ}$ & & 2,73 & 2,17 & 29,20 & 15,35 & 73,80 \\
\hline \multirow[t]{2}{*}{ Méula } & & & & & & & • & & & 87,14 \\
\hline & $41-1$ & 7,35 & & 15,05 & & 2,28 & 2,14 & 33,07 & 20,58 & 60,47 \\
\hline \multirow[t]{3}{*}{$R_{5}$} & $41-2$ & 6,03 & & 12,33 & & 2,42 & 1.73 & 26,69 & 16,96 & 66,19 \\
\hline & $34-1$ & 8,75 & I & 24,60 & & 2,08 & 2,20 & 33,79 & 16,58 & 88,00 \\
\hline & $34-2$ & 7,43 & & 16,32 & & 2,12 & 2,13 & 27,99 & 11,57 & 67,56 \\
\hline Méd1a & & & & & 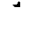 & & & & & 75,55 \\
\hline
\end{tabular}


TABElA 3 - Matéria seca produzida aos 120 dias, por cana-de-aç car Saccharum spp cv. NA56-79, cultivadas em solução nutritiva contendo 5 concentrações de potássio, de senvolvidas em condições de casa de vegetação.

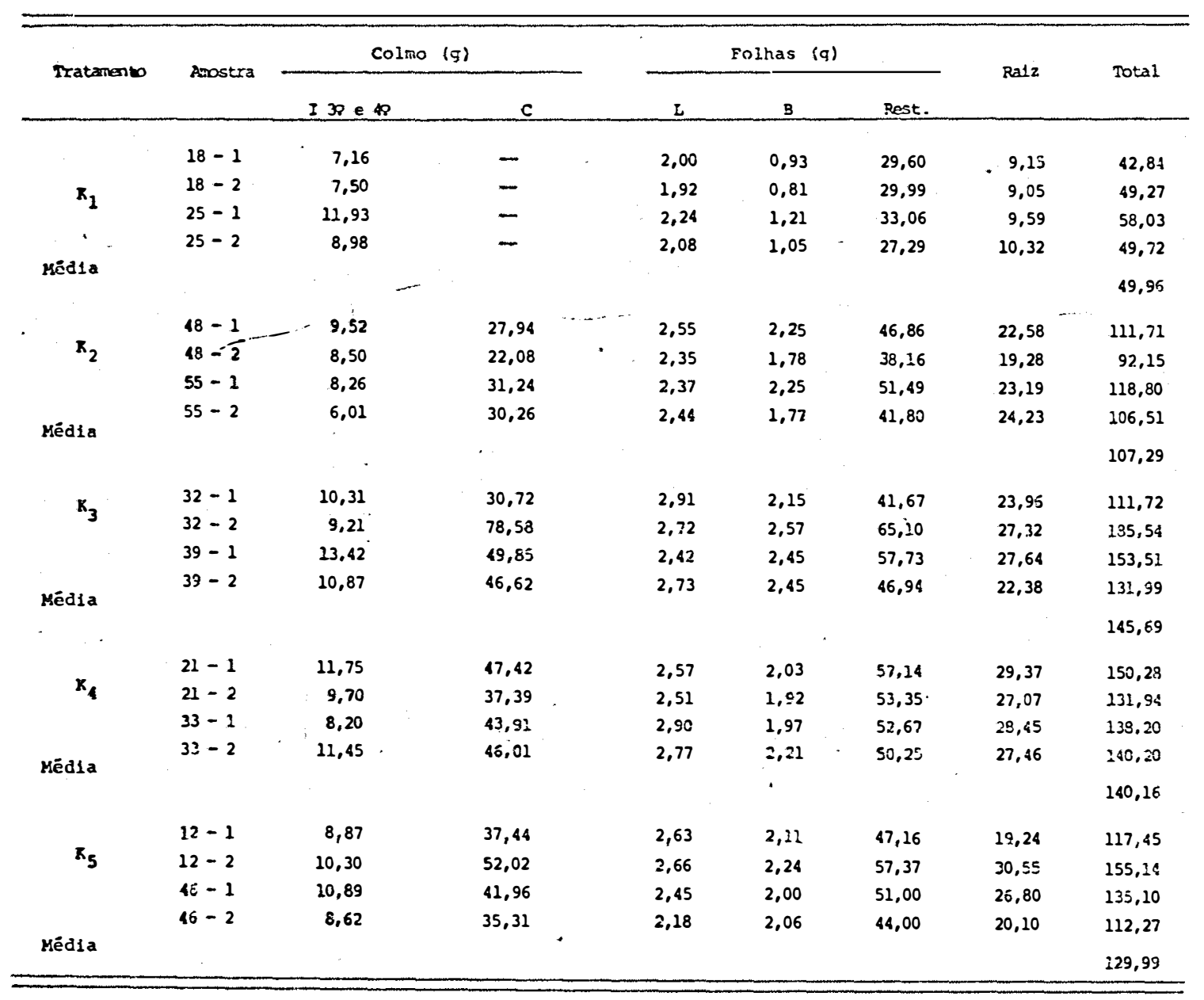


TABELA 4 - Matéria seca produzida aos 135 dias, por cana-de-aç car Saccharum spp CV. NA56-79, cultivadas em solução nutritiva contendo 5 concentrações de potássio, de senvolvidas em condições de casa de vegetação.

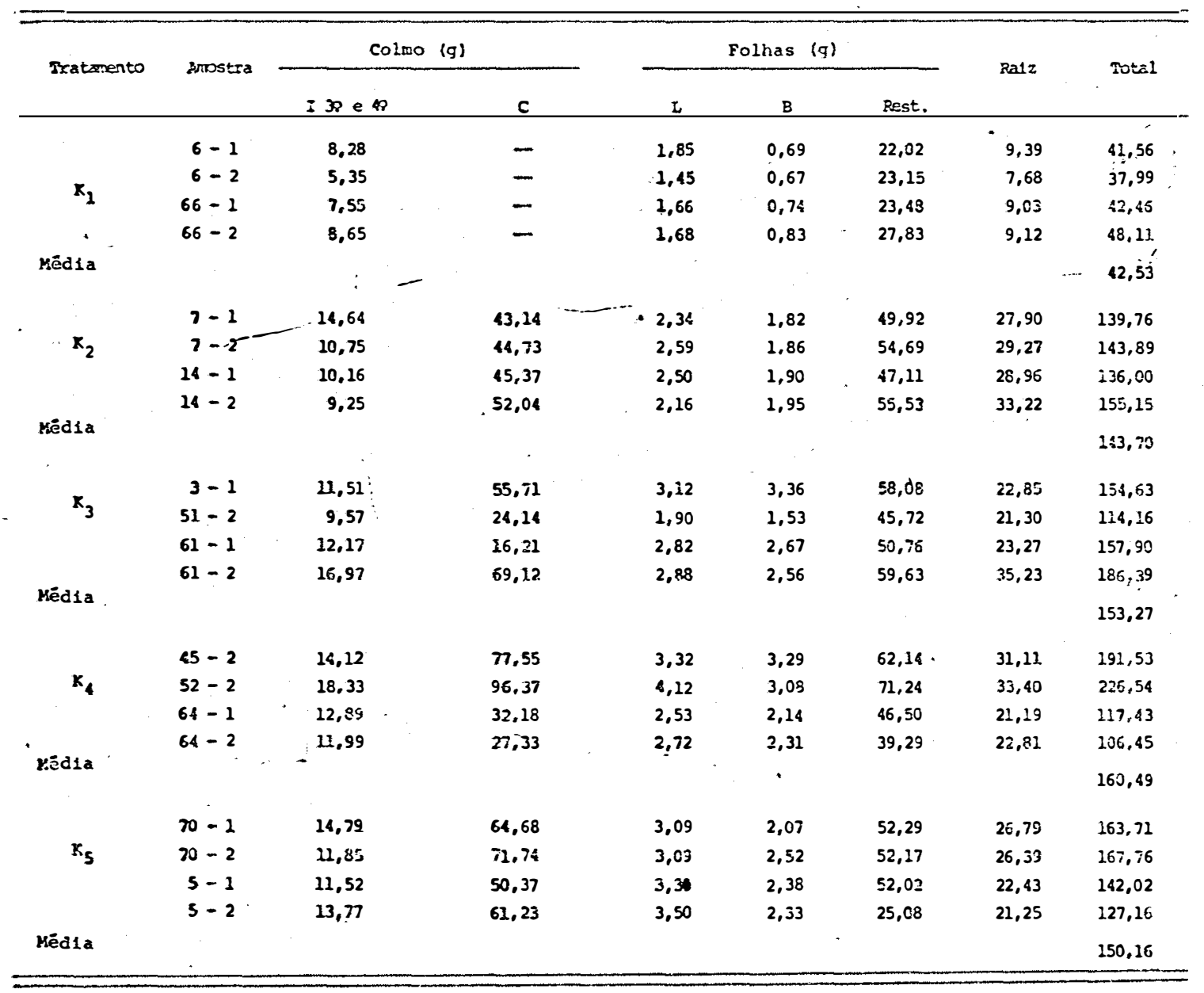


TABELA 5 - Matéria seca produzida aos 150 dias, por cana-de-aç्َ car Saccharum spp cv. NA56-79, cultivadas em solução nutritiva contendo 5 concentrações de potássio, de senvolvidas em condições de casa de vegetação.

\begin{tabular}{|c|c|c|c|c|c|c|c|c|c|}
\hline \multirow{2}{*}{ Tratanerito } & \multirow{2}{*}{ Arustra } & \multicolumn{2}{|c|}{ Colmo $(g)$} & \multicolumn{4}{|c|}{ Folhas (q) } & \multirow{2}{*}{ Radz } & \multirow{2}{*}{ Total } \\
\hline & & I $30 \in 48$ & c & & L. & $B$ & Pest. & & \\
\hline \multirow{3}{*}{$x_{1}$} & $59-1$ & 8,64 & - & & 0,96 & 0,46 & 29,00 & 9,55 & 48,63 \\
\hline & $30-1$ & 6,30 & $-\quad-$ & & 1,71 & 1,53 & 20,95 & $.8,66$ & 39,15 \\
\hline & $1-1$ & 8,01 & - & & 1,19 & 0,68 & 27,34 & 13,33 & 50,55 \\
\hline \multirow{2}{*}{ Média } & $54-1$ & 8,58 & - & & 1,55 & 0,71 & 26,22 & 10,07 & 47,13 \\
\hline & : & & & & & & & & 46,36 \\
\hline \multirow{4}{*}{$x_{2}$} & $2-1$ & $.11,57$ & 67,83 & ........... & 2,95 & 2,13 & 58,24 & 33,68 & 376,40 \\
\hline & $2-2$ & 9,75 & 71,01 & & 3,09 & 2,21 & 61,58 & . 36,18 & 183,82 \\
\hline & $60-1$ & 11,03 & $.21,32$ & & 3,12 & 2,73 & 69,07 & 32,22 & $199, ; 9$ \\
\hline & $60-2$ & 12,92 & 84,27 & & 3,08 & 2,53 & 03,52 & 43,14 & 208,49 \\
\hline Mēdla & & : & & & & & & & 192,05 \\
\hline \multirow{3}{*}{$k_{3}$} & $10-1$ & 10,83 & 81,13 & & 3,51 & 3,29 & 60,89 & 21,00 & 130,65 \\
\hline & $27-1$ & 15,87 & 85,55 & & 2,66 & 2,02 & 64,13 & 25,90 & 195,13 \\
\hline & $27-2$ & $25,93 !$ & 92,45 & & 2,65 & 1,99 & 73, i5 & 27,72 & 213,89 \\
\hline \multirow{2}{*}{ Méd1a } & $20-1$ & 12,73 & 79,56 & & 3,09 & 2,53 & 66,51 & 29,60 & 194,02 \\
\hline & & & . & & & & & & 196,27 \\
\hline \multirow{3}{*}{$x_{4}$} & $57-1$ & 11,44 & 89,02 & & 3,47 & 2,68 & 70,89 & 39,26 & 216,76 \\
\hline & $57-2$ & 12,35 & 87,45 & & 3,59 & 2,78 & 69,09 & 44,15 & 219,42 \\
\hline & $1-2$ & 12,51 & 68,26 & & 2,42 & 2,09 & $55,90^{\circ}$ & 21,53 & 162,71 \\
\hline \multirow{2}{*}{ Média } & $11-2$ & 14,47 & 88,50 & & 3,58 & 3,51 & 69,03 & 24,40 & 203,49 \\
\hline & & & & & & - & & & 200,55 \\
\hline \multirow{4}{*}{$x_{5}$} & $29-1$ & 19,86 & 104,61 & & 3,46 & 2,67 & 75,99 & 36,57 & 245,15 \\
\hline & $29-2$ & 11,93 & 109,93 & & 3,41 & 2,75 & 72,00 & 38,60 & 233,65 \\
\hline & $36-i$ & 12,39 & 97,04 & & 2,90 & 2,33 & 66,89 & 43,57 & 225,12 \\
\hline & $58-1$ & $\quad 19,52$ & 126,85 & & 3,74 & 3,23 & 77,38 & 41,48 & 272,20 \\
\hline Méd1a &. & & & $\cdot$ & & & & & 245,28 \\
\hline
\end{tabular}


TABEIA 6 - Matéria seca produzida aos 168 dias, por cana-de-aç $\underline{\bar{Z}}$ car Saccharum spp CV. NA56-79, cultivadas em solução nutritiva contendo 5 concentrações de potässio, de senvolvidas em condições de casa de vegetação.

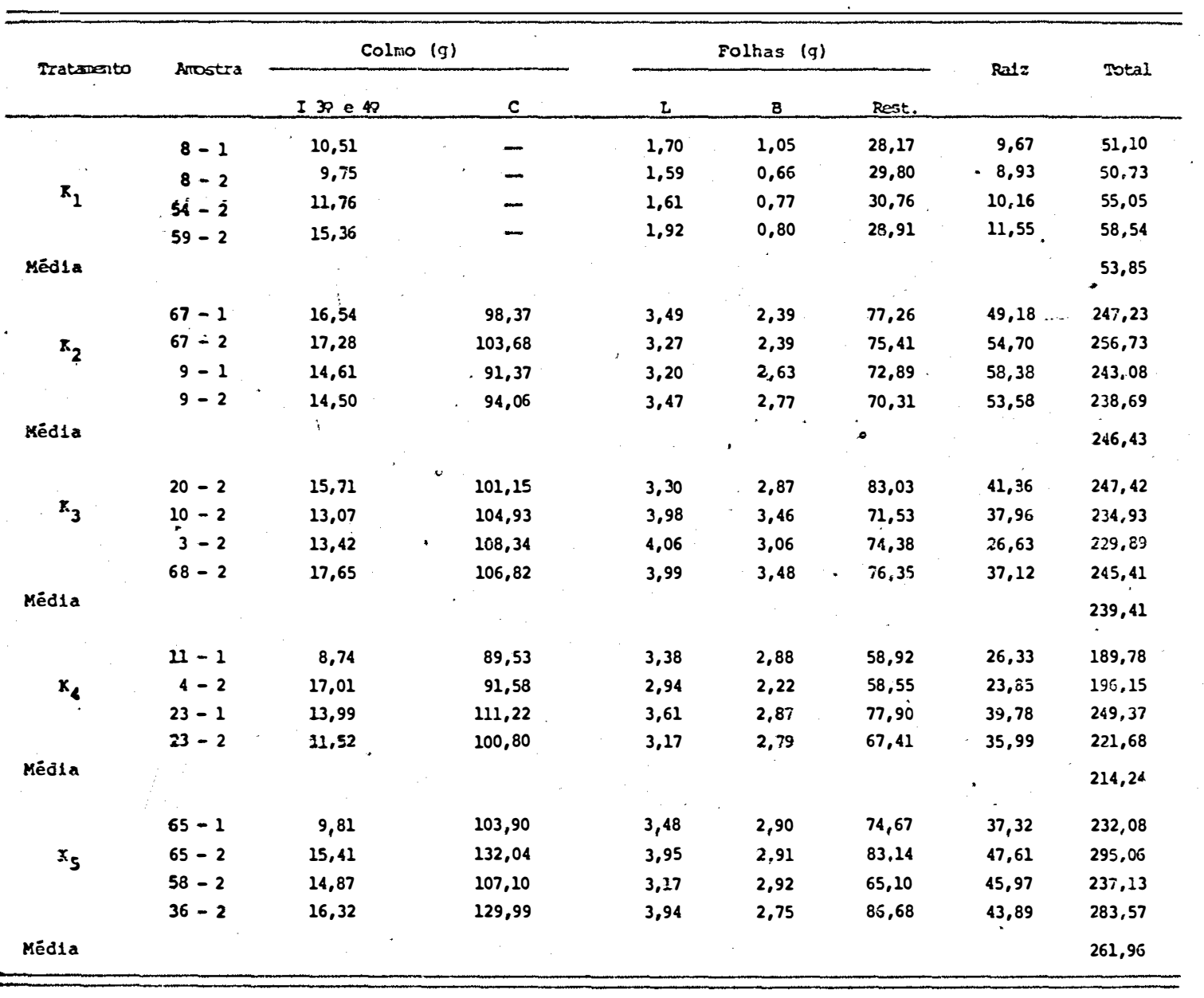


TABELA 7 - Matéria seca produzida aos 180 días, por cana-de-açü car saccharum spp CV. NA56-79, cultivadas em solução nutritiva contendo 5 concentrações de potássio, de senvolvidas em condiçöes de casa de vegetação.

\begin{tabular}{|c|c|c|c|c|c|c|c|c|c|c|}
\hline \multirow{2}{*}{ Tractsesto } & \multirow{2}{*}{ Arostra } & \multicolumn{3}{|c|}{ Colmo (g) } & & \multicolumn{3}{|c|}{ Foltias $(g)$} & \multirow{2}{*}{ Raiz } & \multirow{2}{*}{ Total } \\
\hline & & $I 38 \simeq 48$ & & c & & L & 3 & Rest. & & \\
\hline \multirow{4}{*}{$x_{1}$} & $1-2$ & 20,05 & & - & & 2,07 & 1,02 & 27,88 & $\cdot 14,66$ & 65,68 \\
\hline & $30-2$ & 23,15 & & - & & 2,30 & 1,19 & 37,68 & 10,50 & 74,82 \\
\hline & $37-1$ & 10,74 & & - & & 2,01 & 0,88 & 26,85 & 9,42 & 49,90 \\
\hline & $37-2$ & 10,37 & & - & & 1,99 & 0,76 & $38,0 \mathrm{C}$ & 9,70 & 60,82 \\
\hline \multirow[t]{2}{*}{ sécila } & & $i$ & $\cdots$ & & & & & & & 62,80 \\
\hline & $31-1$, & 12,51 & & 131,43 & & 3,71 & 3,13 & 93,00 & 50,29 & 294,09 \\
\hline \multirow{3}{*}{$\mathbf{R}_{2}$} & $32-2$ & 9,12 & & 104,85 & & 3,32 & 2,98 & 64,95 & 45,97 & 231,19 \\
\hline & $38-1$ & 13,28 & & 317,46 & & 3,39 & 2,91 & 88,46 & 58,53 & 284,03 \\
\hline & $38-2$ & 13,33 & & 106,71 & & 3.24 & 2,80 & 67,67 & 62,45 & 256,10 \\
\hline Méaía & & & & & & & & & & 256,35 \\
\hline \multirow{4}{*}{$x_{3}$} & $15-1$ & 11,27 & & 107,18 & & 3,47 & 3,16 & 74,00 & 54,30 & 253,38 \\
\hline & $15-2$ & 19,12 & . & 128,04 & & 3,63 & 2,89 & 82,03 & 49,30 & 285,01 \\
\hline & $22-1$ & 17,07 & & 127,04 & & 3,39 & 3,09 & 82,72 & 64,77 & 298,08 \\
\hline & $22-2$ & 11,34 & $\ldots$ & 120,45 & & 3,42 & 3,03 & 82,89 & 50,16 & 271,29 \\
\hline \multirow[t]{2}{*}{ Mèdśa } & & & & & & & & & & 276,94 \\
\hline & $16-1$ & 21,41 & & 142,77 & & 3,92 & 2,91 & 83,08 & 39,00 & 283,09 \\
\hline \multirow{3}{*}{$x_{4}$} & $16-2$ & 16,01 & & 136,47 & & 3,74 & 2,86 & $80,54^{\circ}$ & 31,54 & 271,20 \\
\hline & $69-1$ & 15,73 & & 124,24 & & 3,53 & 3,00 & $.7 \varepsilon, 00$ & 32,98 & 253,48 \\
\hline & $69-2$ & 17,55 & & 149,22 & & 3,56 & 3,12 & 92,12 & 47,84 & 313,41 \\
\hline \multirow[t]{2}{*}{ Médía } & & & & & & & & & & 280,29 \\
\hline & $17-1$ & 19,54 & & 145,88 & & 3,94 & 3,15 & 74,58 & 38.36 & 285,45 \\
\hline \multirow[t]{3}{*}{$x_{5}$} & $17-2$ & 17,98 & & 144,85 & & 3,27 & 3,01 & 90,99 & 36,50 & 256,60 \\
\hline & $24-1$ & 8,20 & & 120,48 & & 3,36 & 3,83 & 66,12 & 23,34 & $225,3 j$ \\
\hline & $24-2$ & 9,52 & . & 124,71 & . & 3,20 & 3,20 & 76,07 & 33,05 & 250,11 \\
\hline Kēdia & & & & & & & & & & 204,32 \\
\hline
\end{tabular}


TABELA 8 - Açúcar redutor (AR), açücares redutores (ART) e sa carose estimada no caldo dos I 39 e 4 \% de cana - de. açūcar, Saccharum spp cv. NA56-79, aos 90 dias, con duzidas em solução nutritiva contendo 5 concentra ções de potāssio em condições de casa de vegetação.

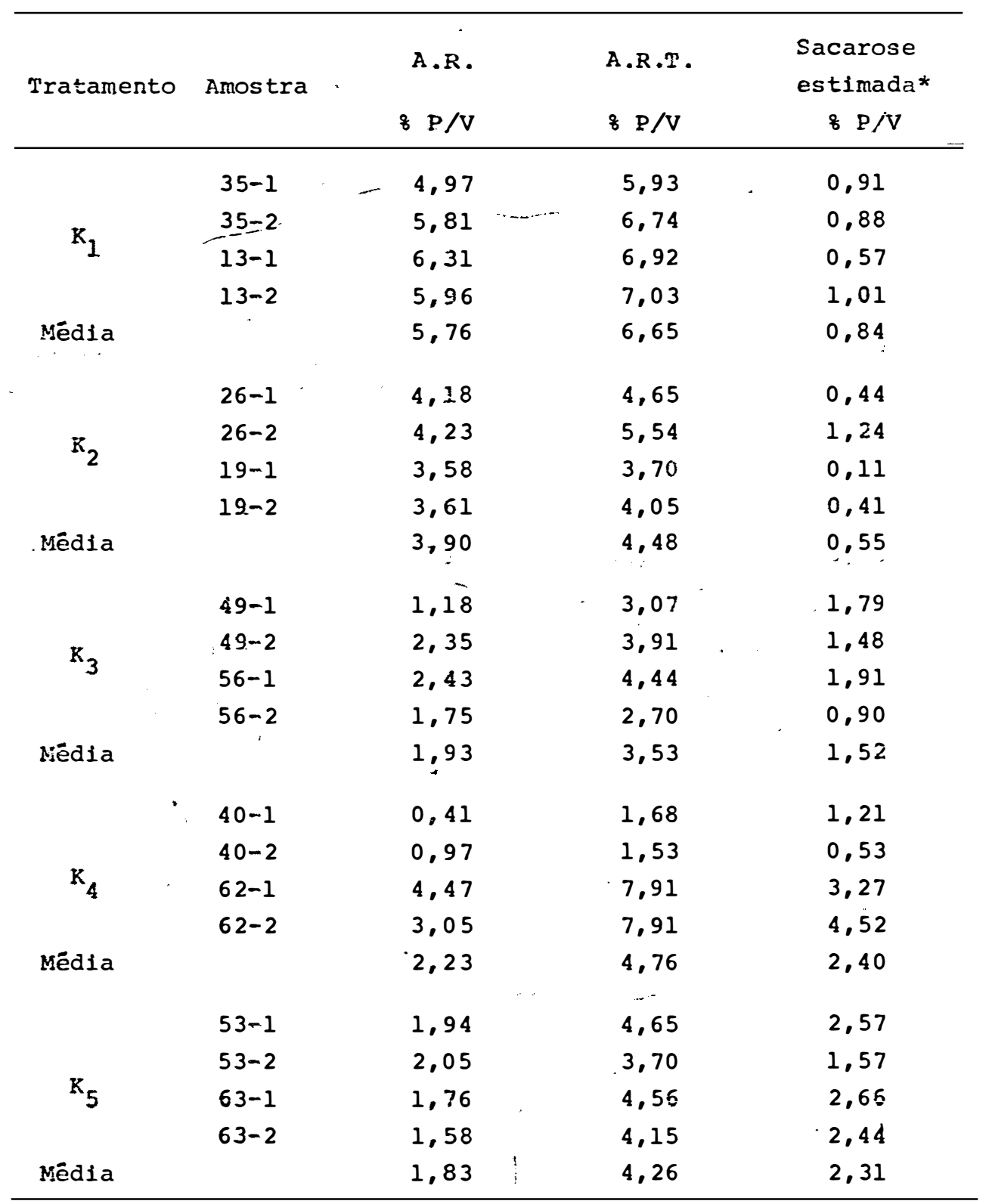

*_Sacarose estimada $=$ ART - AR $\times 0,95$. 
TABELA 9 - Açúcar redutor (AR), açūcares redutores (ART) e sa carose estimada no caldo dos $I 30$ e 40 de cana-de.. açūcar Saccharum spp cv. NA56-79, aos 105 dias, con duzidas em solução nutritiva contendo 5 concentra ções de potãssio em condições de casa de vegetação.

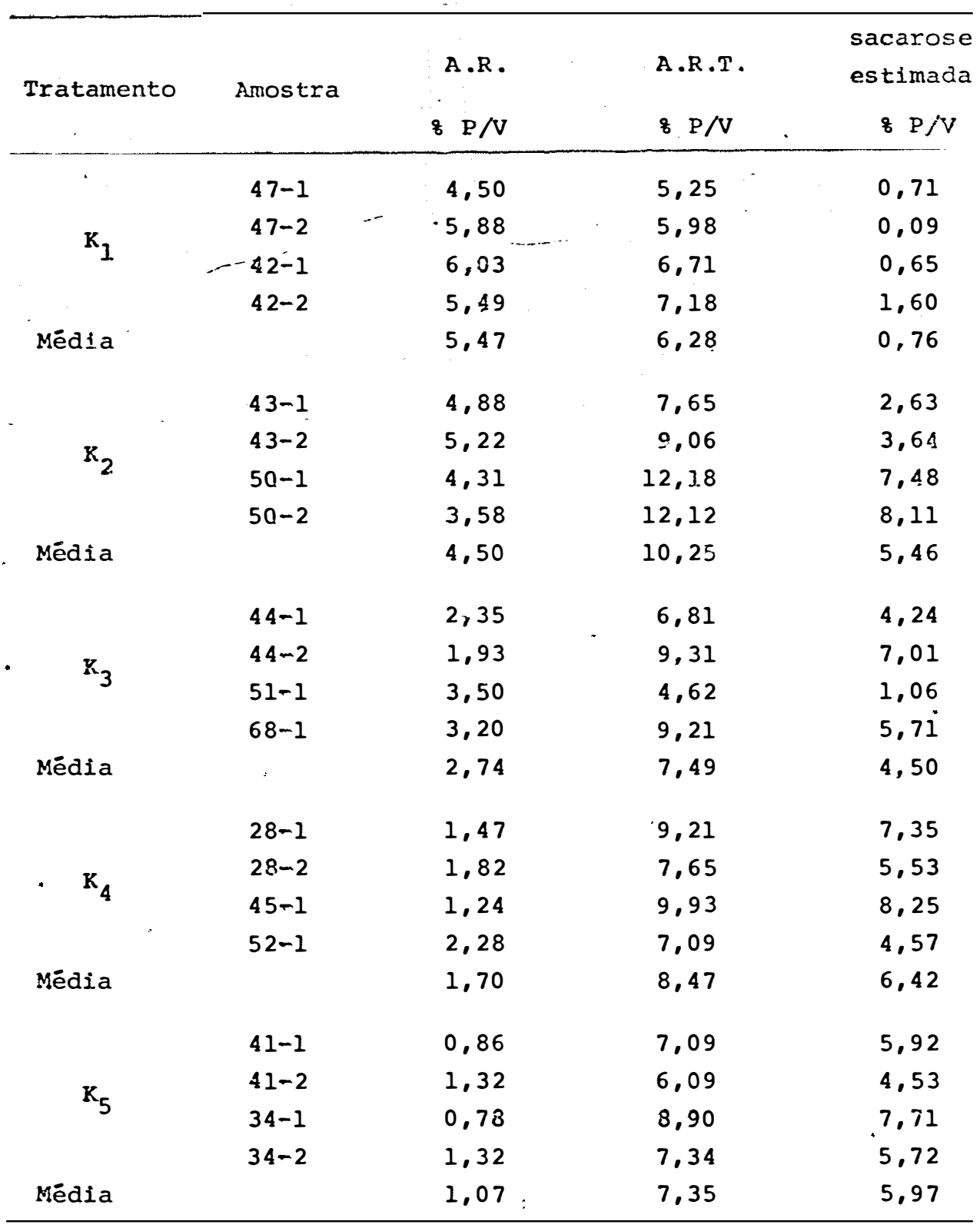


TABELA 10 - Açūcar redutor (AR), açūcares redutores (ART) e sa carose estimada no caldo dos I 39 e 49 de cana-deaçúcar, Saccharum spp CV. NA56-79, aos 120 dias, conduzidos em solução nutritiva contendo 5 concen trações de potássio em condições de casa de vege tação.

\begin{tabular}{|c|c|c|c|c|}
\hline Tratamento & Amostra & $\begin{array}{l}\text { A.R. } \\
\& P / V\end{array}$ & $\begin{array}{l}A \cdot R \cdot T \text {. } \\
\& \mathrm{~B} / \mathrm{V}\end{array}$ & $\begin{array}{c}\text { sacarose } \\
\text { estimada } \\
\& \mathrm{P} / \mathrm{V}\end{array}$ \\
\hline$\cdot$ & $18-1$ & 5.10 & 6,34 & 1,18 \\
\hline \multirow{3}{*}{$\mathrm{k}_{1}$} & $18-2$ & 4,90 & 6,73 & 1,74 \\
\hline & $-25-1$ & $5,72^{\cdots}$ & 6,60 & 0,84 \\
\hline & $25-2$ & 5,20 & 7.23 & 1,92 \\
\hline \multirow[t]{3}{*}{ Média } & & 5,23 & 8,40 & 1,42 \\
\hline & $48-1$ & 3,47 & 10,79 & 6,95 \\
\hline & $48-2$ & 3,58 & 11,42 & 7,45 \\
\hline \multirow[t]{2}{*}{$\mathrm{K}_{2}$} & $55-1$ & 2,40 & 12,38 & 9,48 \\
\hline & $55-2$ & 2,86 & 12,22 & 8,89 \\
\hline \multirow[t]{3}{*}{ Média } & & 3,01 & 11,70 & 8,19 \\
\hline & $32-1$ & $-3,05$ & 13,17 & 9,61 \\
\hline & $32 \cdots 2$ & 1,60 & 14,60 & 12,35 \\
\hline \multirow[t]{2}{*}{$k_{3}$} & $39-1$ & 2,64 & $12 ; 95$ & 9,79 \\
\hline & $39-2$ & 2,17 & 15,87 & 13,05 \\
\hline \multirow[t]{3}{*}{ Média } & , & 2,36 & 14,24 & 11,20 \\
\hline & $21-1$ & 1.01 & 11,90 & 10,34 \\
\hline & $21-2$ & 0.72 & 13,26 & 11,91 \\
\hline \multirow{2}{*}{. $\quad K_{4}$} & $33-1$ & 1,03 & 12,69 & 11,08 \\
\hline & $33-2$ & 1,58 & 13,96 & 11,76 \\
\hline \multirow[t]{3}{*}{ Média } & & 1,08 & 12,95 & 11,27 \\
\hline & $12-1$ & 0.83 & 12,38 & 10,97 \\
\hline & $12-2$ & 0,53 & 13,17 & 12,01 \\
\hline \multirow[t]{2}{*}{$k_{5}$} & $46-1$ & 0.61 & 9,84 & 8,77 \\
\hline & $46-2$ & 0,64 & 11,90 & 10,70 \\
\hline Média & & 0.65 & 11,82 & 10,61 \\
\hline
\end{tabular}


TABELA 11 - Açúcar redutor (AR), açũcares redutores (ART) e sa carose estimada no caldo dos I 39 e 49 de cana - de. açūcar, Saccharum spp cv. NA56-79, aos 135 dias, conduzidos em solução nutritiva contendo 5 concen trações de potássio em condições de casa de vegetą ção.

\begin{tabular}{|c|c|c|c|c|}
\hline Tratamento & Amostra & $\begin{array}{l}\text { A.R. } \\
\& \mathrm{P} / \mathrm{V}\end{array}$ & $\begin{array}{l}\text { A.R.T. } \\
\& \mathrm{P} / \mathrm{V}\end{array}$ & $\begin{array}{c}\text { sacarose } \\
\text { estimada } \\
\& \mathrm{~F} / \mathrm{V}\end{array}$ \\
\hline \multirow{4}{*}{$\mathrm{k}_{1}$} & $6-1$ & 4,62 & 7,19 & 2,44 \\
\hline & $6-2$ & 4,16 & 8,83 & 4,44 \\
\hline & $66-1 \ldots$ & $.4,46$ & 7,90 & 3,27 \\
\hline & $-66-2$ & $-4 ; 66$ & 8,43 & 3,58 \\
\hline Média & & 4,47 & 8,08 & 3,43 \\
\hline \multirow{4}{*}{$\mathrm{K}_{2}$} & $7-1$ & 2,69 & 14,32 & 11,05 \\
\hline & $7-2$ & 1,97 & 15,19 & 12,56 \\
\hline & $14-1$ & 2,12 & 13,79 & 11,09 \\
\hline & $14-2$ & 1,65 & 16,37 & 13,98 \\
\hline Média & & 2,10 & 14,91 & 12,17 \\
\hline \multirow{4}{*}{$k_{3}$} & $3-1$ & 1,77 & 15,50 & 13,04 \\
\hline & $51-2$ & 2,38 & 13,33 & 10,40 \\
\hline & $61-1$ & 1,46 . & 16,12 & 13,93 \\
\hline & $61-2$ & 1,86 & 16,43 & 13,84 \\
\hline \multirow[t]{2}{*}{ Média } & & 1,86 & 15,34 & 12,80 \\
\hline & $45-2$ & 0,88 & 12,96 & 11,48 \\
\hline \multirow{3}{*}{$\mathrm{K}_{4}$} & $52-2$ & 1,44 & 15,81 & 13,65 \\
\hline & $64-1$ & 2,03 & 9,50 & 7,10 \\
\hline & $64-2$ & 1,98 & 8,90 & 6,57 \\
\hline \multirow[t]{2}{*}{ Média } & & 1,58 & 11,79 & 10,74 \\
\hline & $70-1$ & 0,75 & 14,57 & 13,13 \\
\hline \multirow{3}{*}{$k_{5}$} & $70-2$ & 0,33 & 15,19 & 14,12 \\
\hline & $5-1$ & 0,96 & 11,93 & 10,42 \\
\hline & $5-2$ & 0,81 & 14,51 & 13,02 \\
\hline Média & & 0,71 & 14,05 & 12,67 \\
\hline
\end{tabular}


TABELA 12 - Açūcar redutor (AR), açūcares redutores (ART) e sa carose estimada no caldo dos I 39 e $4 \%$ de cana-deaçūcar, Saccharum spp CV. NA56-79, aos 150 dias, conduzidos em solução nutritiva contendo 5 concen trações de potássio em conâições de casa de vegetą ção.

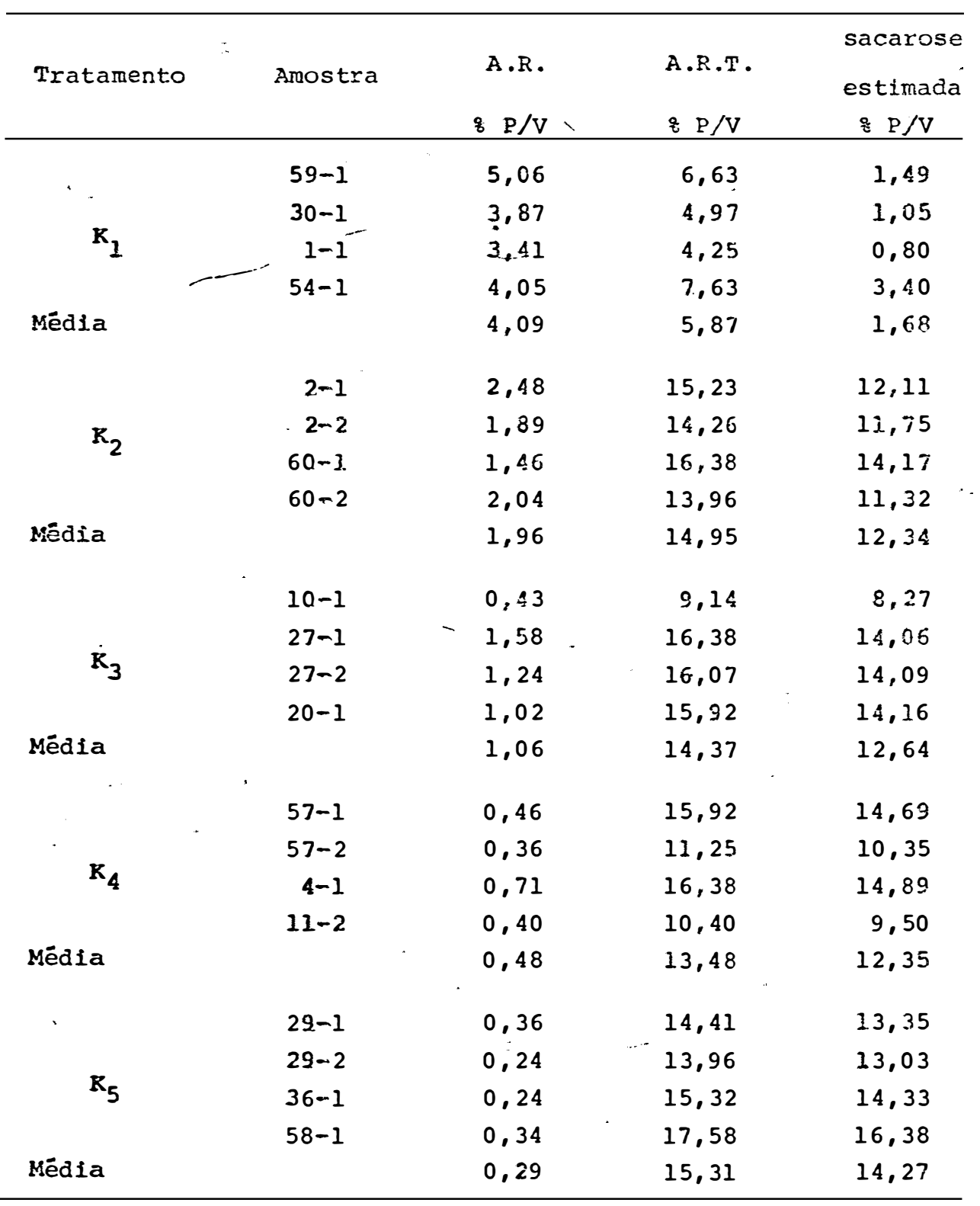


TABEIA 13 - Açŭcar redutor (AR), açũcares redutores (ART) e są carose estimada no caldo dos I 39 e 4 \% de cana - deaçŭcar, Saccharum spp CV. NA56-79, aos 168 dias, conduzidas em solução nutritiva contendo 5 concen trações de potāssio em condições de casa de vegeta ção.

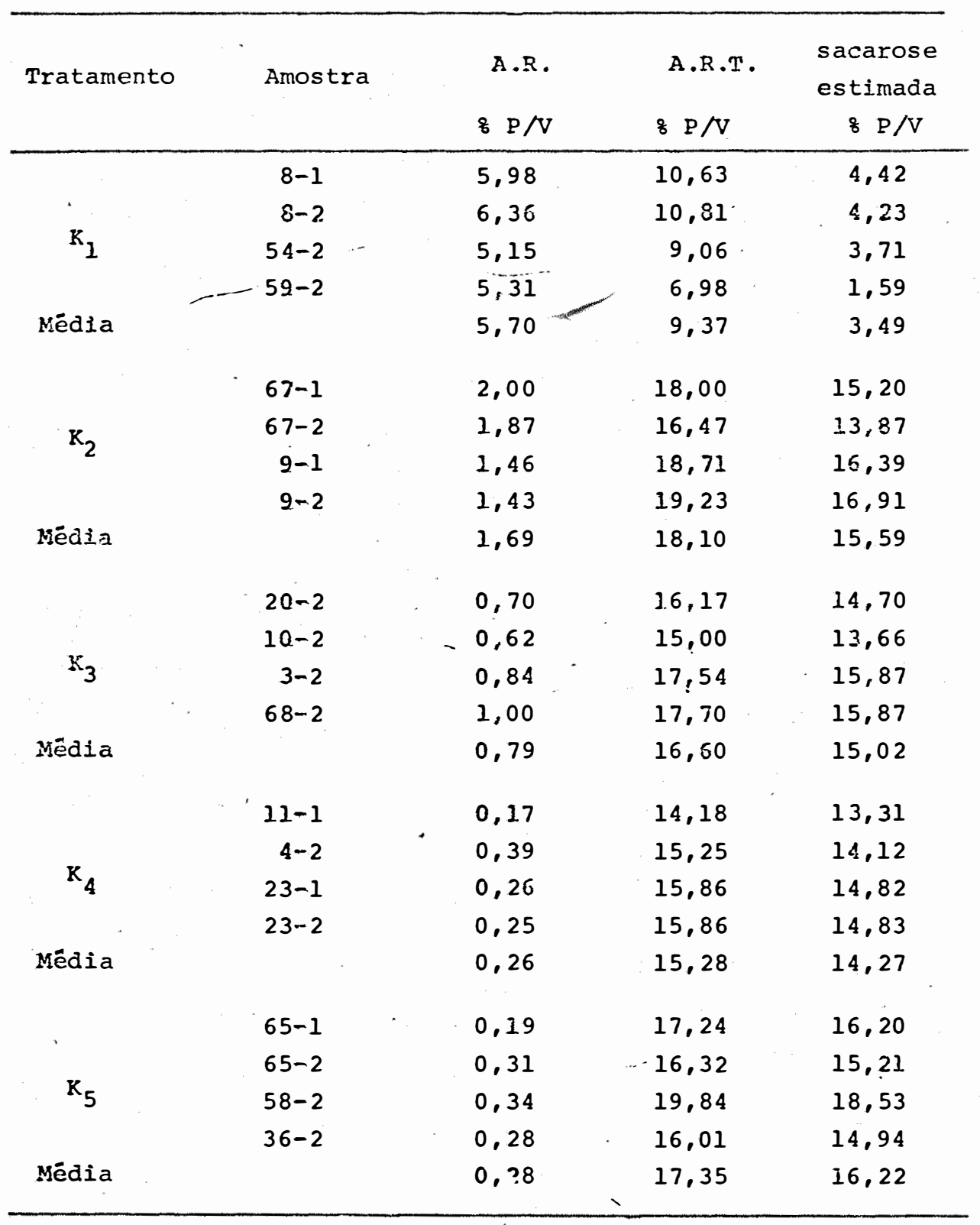


TABELA 14 - Açūcar redutor (AR), açūcares redutores (ART) e sa carose estimada no caldo dos I 39 e $4 \%$ de cana - de.. açúcar, Saccharum spp cv. NA56-79, aos 180 dias, conduzidas em solução nutritiva contendo 5 concen trações de potássio em condições de casa de vegetą ร̧ão.

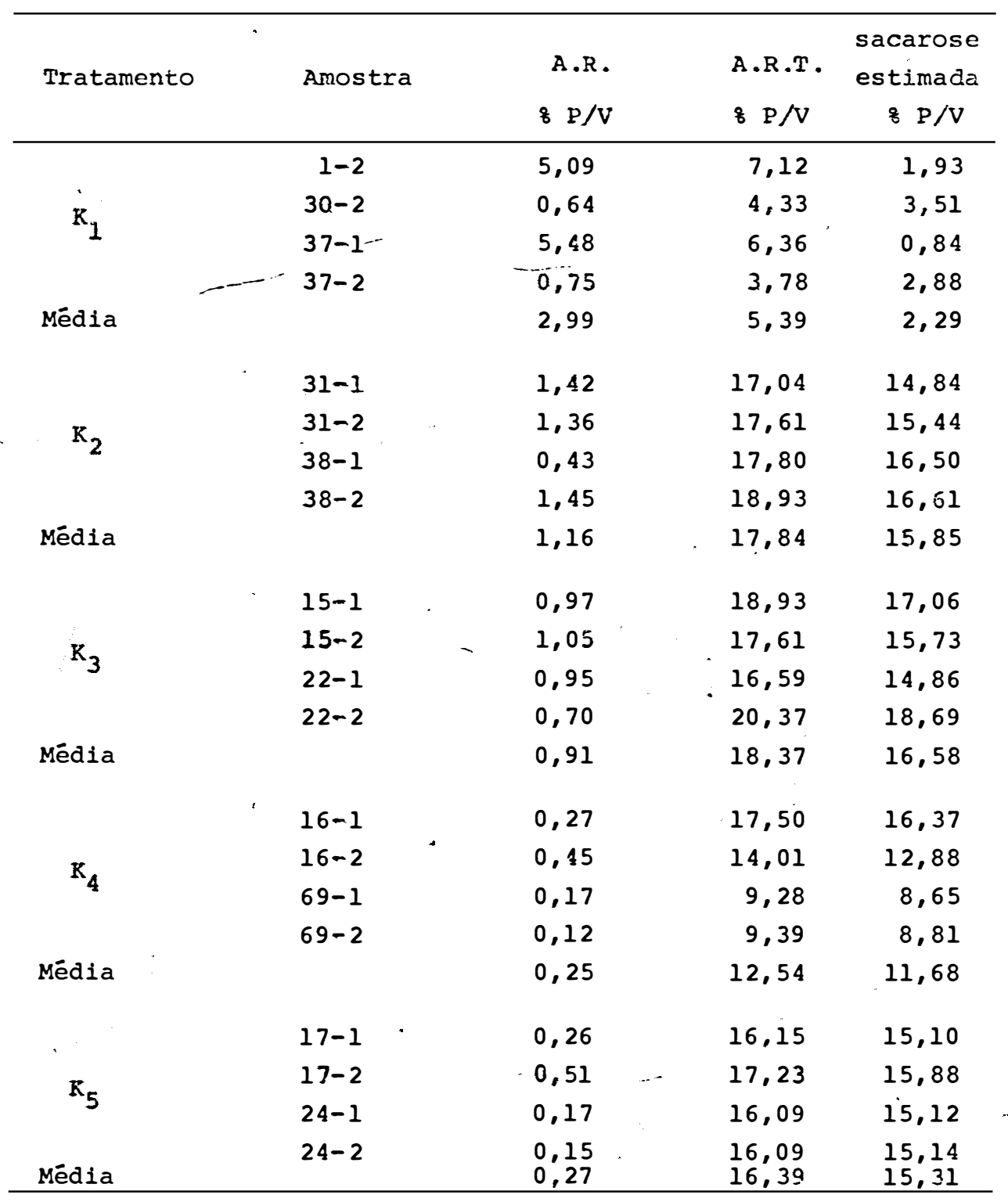


77.

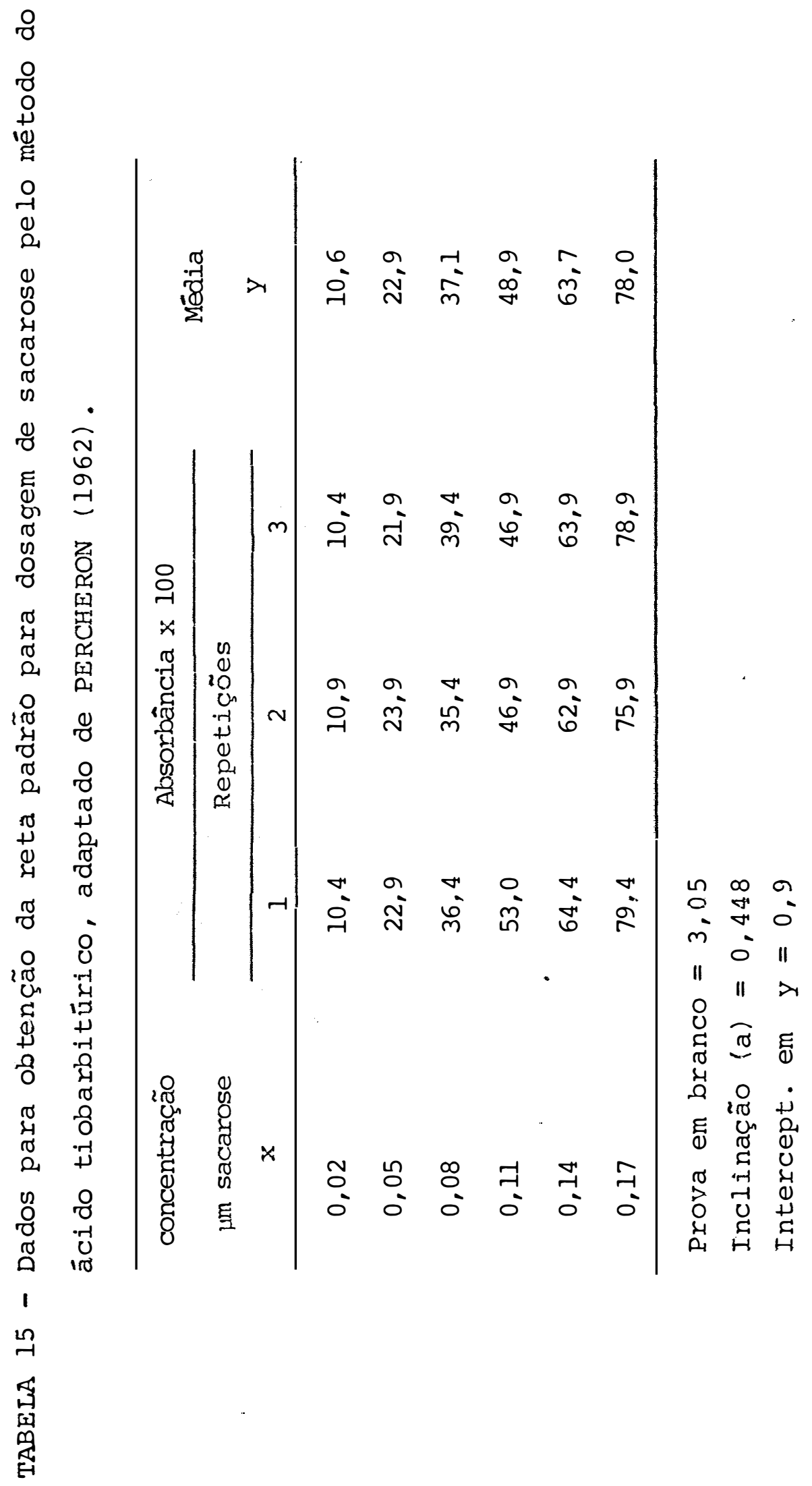


TABELA 16 - Características morfológicas das plantas de cana-deaçúcar, colhidas aos 90 dias.

\begin{tabular}{|c|c|c|c|c|c|c|}
\hline Trat. & Plantas & $\begin{array}{l}\text { altura } \\
\text { (cm) }\end{array}$ & $\begin{array}{c}n 8 \text { de } \\
\text { internós }\end{array}$ & & $\begin{array}{l}\text { ne de } \\
\text { erfilhos ( ) }\end{array}$ & \\
\hline \multirow{4}{*}{$k_{1}$} & $35-1$ & 49 & 6 & & - & \\
\hline & $35-2$ & 45 & 6 & & -- & \\
\hline & $138-1$ & 53 & 7 & & - & \\
\hline & $38-2$ & 51 & 7 & & -- & \\
\hline \multirow{4}{*}{$\mathrm{k}_{2}$} & $26-1$ & 105 & 5 & 2 & $(3,0 ; 2,0)$ & \\
\hline & $26-2$ & 120 & 6 & 2 & $(7,0 ; 7,0)$ & \\
\hline & $19-1$ & 106 & 6 & 2 & $(4,0 ; 6,0)$ & \\
\hline & $19-2$ & 103 & 6 & 1 & $(3,5)$ & \\
\hline \multirow{4}{*}{$\mathrm{k}_{3}$} & $49-1$ & 78 & 5 & 2 & $(0,5 ; 0,5)$ & \\
\hline & $49-2$ & 87 & 5 & 3 & $(7,0 ; 5,0 ;$ & 5,0 \\
\hline & $56-1$ & 86 & 5 & 2 & $(2,0 ; 0,5)$ & \\
\hline & $56-2$ & 90 & 6 & 2 & $(4,0 ; i, 0)$ & \\
\hline \multirow{4}{*}{$\mathrm{K}_{4}$} & $40-1$ & 79 & 5 & 2 & $(4,0 ; 3,0)$ & \\
\hline & $40-2$ & 76 & 4 & 3 & $(7,0 ; 5,5 ;$ & $3,0)$ \\
\hline & $62-1$ & 81 & 5 & & -- & \\
\hline & $62-2$ & 82 & 5 & & -- & \\
\hline \multirow{4}{*}{$\mathrm{k}_{5}$} & $53-1$ & 122 & 6 & 3 & $(6,0 ; 6,0 ;$ & $2,0)$ \\
\hline & $53-2$ & 92 & 6 & & -- & \\
\hline & $63-1$ & 118 & 6 & 2 & $(5,0 ; 5,0)$ & \\
\hline & $63-2$ & 113 & 7 & 2 & $(6,0 ; 1,0)$ & \\
\hline
\end{tabular}

Comprimento dos perfilhos em $\mathrm{cm}$. 
TABELA 17 - Características morfolögicas das plantas de cana-de. açūcar, colnidas aos 10.5 dias.

\begin{tabular}{|c|c|c|c|c|c|c|c|}
\hline Trat. & Plantas & $\begin{array}{l}\text { Altura } \\
\text { (cm) }\end{array}$ & $\begin{array}{c}\text { no de } \\
\text { internós }\end{array}$ & & $\begin{array}{c}\text { no } \\
\text { perf }\end{array}$ & $\begin{array}{c}\text { de } \\
\text { filhos }\end{array}$ & \\
\hline \multirow{4}{*}{$k_{1}$} & $47-1$ & 61 & 9 & & & -- & \\
\hline & $47-2$ & 52 & 8 & & & -- & \\
\hline & $42-1$ & 54 & 8 & & & -- & \\
\hline & $42-2$ & 60 & 10 & & & -- & \\
\hline \multirow{4}{*}{$\mathrm{K}_{2}$} & $43-1$ & 138 & 9 & 2 & $(3,0 ;$ & $(14,0)$ & \\
\hline & $43-2$ & 140 & 9 & 3 & $(2,0 ;$ & $; 2,0 ;$ & $6,0)$ \\
\hline & $50-1$ & 146. & 9 & 2 & $(9,0$; & $8,0)$ & \\
\hline & $50-2$ & 147 & 9 & 2 & $(10,0$ & $: 13,0$ & \\
\hline \multirow{4}{*}{$k_{3}$} & $44-1$ & 142 & 9 & 3 & $(1,0 ;$ & $3,0:$ & $2,0)$ \\
\hline & $44-2$ & 144 & 8 & 3 & $(9,0 ;$ & 9,$0 ;$ & $2,0)$ \\
\hline & $51-1$ & 135 & 8 & 2 & $(7,0 ;$ & $9,0)$ & \\
\hline & $68-1$ & 151 & 8 & 2 & $(3,0 ;$ & $(5,0)$ & \\
\hline \multirow{4}{*}{${ }_{4}^{K}$} & $28-1$ & 158 & 9 & 1 & $(3,0)$ & & \\
\hline & $28-2$ & 156 & 9 & & & -- & \\
\hline & $45-1$ & 135 & 9 & 2 & $(1,5 ;$ & $3,0)$ & \\
\hline & $52-1$ & 135 & 8 & 1 & $(1,5)$ & & \\
\hline \multirow{4}{*}{$k_{5}$} & $41-1$ & 122 & 9 & 2 & $(4,0 ;$ & $5,0)$ & \\
\hline & $41-2$ & 112 & 8 & 3 & $(6,0$; & 3,$0 ;$ & $1,5)$ \\
\hline & $34-1$ & 121 & 9 & 3 & $(4,0 ;$ & 6,$0 ;$ & $4,0)$ \\
\hline & $34-2$ & 116 & 8 & 2 & $(1,5 ;$ & $2,0)$ & \\
\hline
\end{tabular}


TABEIA 18 - Características morfológicas das plantas de cana-deaçúcar, colhidas aos 120 dias.

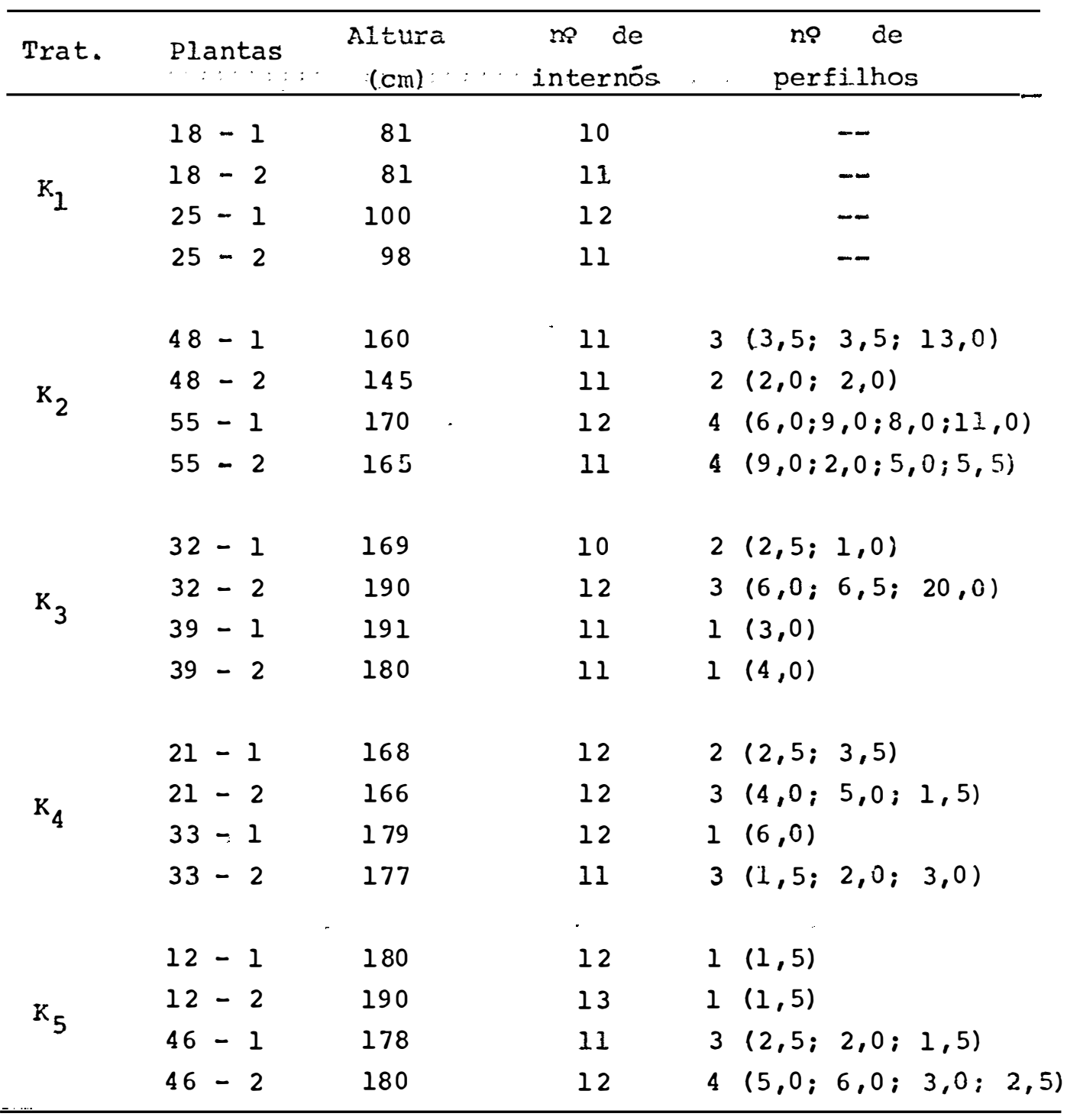


TABELA 19 - Características morfológicas das plantas de cana-deaçūcar, colhidas aos 135 dias.

\begin{tabular}{|c|c|c|c|c|c|c|}
\hline Trat. & $\mathrm{Pla}$ & antas & $\begin{array}{l}\text { altura } \\
\text { (cm) }\end{array}$ & $\begin{array}{c}\text { no de } \\
:: \text { internós }\end{array}$ & & $\begin{array}{c}\text { no de } \\
\text { perxilhos }\end{array}$ \\
\hline \multirow{4}{*}{$k_{1}$} & 6 & -1 & 89 & 13 & & $-\infty$ \\
\hline & 6 & -2 & 72 & 11 & & -- \\
\hline & 66 & -1 & 83 & 11 & & - \\
\hline & 66 & -2 & 90 & 12 & & -- \\
\hline \multirow{4}{*}{$\mathrm{K}_{2}$} & 7 & -1 & 185 & 12 & 2 & $(6,0 ; 3,0)$ \\
\hline & 7 & -2 & 185 & 12 & 3 & $(12,0 ; 8,0 ; 6,0)$ \\
\hline & 14 & -1 & 177 & 13 & & -- \\
\hline & 14 & -2 & 197 & 15 & 4 & $(4,0 ; 3,0 ; 7,0 ; 1,0)$ \\
\hline . & 3 & -1 & 210 & 12 & 4 & $(8,0 ; 3,0 ; 5,0 ; 4,0)$ \\
\hline \multirow{3}{*}{$\mathrm{K}_{3}$} & 51 & -2 & 190 & 14 & 5 & $(9,0 ; 4,0 ; 8,0 ; 8,0 ; 4,0$ \\
\hline & 61 & -1 & 208 & 13 & 3 & $(5,0 ; 5,0 ; 3,0)$ \\
\hline & 61 & -2 & 210 & 13 & 2 & $(5,0 ; 6,0)$ \\
\hline \multirow{4}{*}{$\mathrm{K}_{4}$} & 45 & -2 & 204 & 13 & 4 & $(8,0 ; 2,0 ; 5,0 ; 4,0)$ \\
\hline & 52 & -2 & 230 & 13 & 3 & $(10, ; 5,0 ; 8,0)$ \\
\hline & 64 & -1 & 191 & 11 & 3 & $(5,0 ; 3,0 ; 38,0)$ \\
\hline & 64 & -2 & 199 & 12 & 3 & $(5,0 ; 3,0 ; 25,0)$ \\
\hline \multirow{4}{*}{$\mathrm{K}_{5}$} & 70 & -1 & 195 & 13 & 2 & $(6,0 ; 3,5)$ \\
\hline & 70 & -2 & 203 & 15 & 2 & $(6,0 ; 5,0)$ \\
\hline & 5 & -1 & 217 & 12 & 1 & $(1,0)$ \\
\hline & 5 & -2 & 210 & 12 & 3 & $(3,0 ; 1,0 ; 1,0)$ \\
\hline
\end{tabular}


TABELA 20 - Características morfolögicas das plantás de cana-deaçúcar, colhidas aos 150 dias.

\begin{tabular}{|c|c|c|c|c|c|}
\hline Trat. & Pla & antas & $\begin{array}{l}\text { altura } \\
\text { (cm) }\end{array}$ & $\begin{array}{l}\text { ne de } \\
\text { internös }\end{array}$ & $\begin{array}{c}\text { ne de } \\
\text { perfilhos }\end{array}$ \\
\hline \multirow{4}{*}{$\mathrm{K}_{1}$} & 59 & -1 & 78 & 13 & -- \\
\hline & 30 & -1 & 84 & 12 & -- \\
\hline & 1 & -1 & 79 & 14 & - \\
\hline & 54 & -1 & 89 & 14 & -- \\
\hline \multirow{4}{*}{$\mathrm{K}_{2}$} & & -1 & 222 & 14 & $3(6,5 ; 4,5 ; 3,0)$ \\
\hline & & -2 & 229 & 15 & $2(5,0 ; 7,0)$ \\
\hline & 60 & -1 & 221 & 15 & $\begin{array}{l}5 \underset{(10,5 ; 5,9 ; 6,0 ; 6,0 ;}{5,5)} \\
\quad\end{array}$ \\
\hline & 60 & -2 & 218 & 14 & $3(6,5 ; 5,0 ; 2,5)$ \\
\hline \multirow{4}{*}{$k_{3}$} & 10 & -1 & 231 & 14 & $4(2,0 ; 3,0 ; 5,0 ; 6,0)$ \\
\hline & 27 & -1 & 219 & 14 & $3(5,0 ; 3,0 ; 15,0)$ \\
\hline & 27 & -2 & 221 & 14 & $2(13,0 ; 6,0)$ \\
\hline & 20 & -1 & 211 & 14 & $3(7,5 ; 4,5 ; 2,0)$ \\
\hline \multirow{4}{*}{$\mathrm{K}_{4}$} & 57 & -1 & 216 & 15 & $3(4,0 ; 5,0 ; 5,0)$ \\
\hline & 57 & -2 & 216 & 14 & $\begin{array}{l}5 \quad(4,0 ; 3,0 ; 2,0 ; 2,5 ; \\
2,5)\end{array}$ \\
\hline & 4 & -1 & 223 & 13 & $2(6,0 ; 1,0)$ \\
\hline & 11 & -2 & 226 & 14 & $3(5,0 ; 4,0 ; 4,0)$ \\
\hline \multirow{4}{*}{$\mathrm{K}_{5}$} & 29 & -1 & 229 & 15 & $4(7,0 ; 7,0 ; 10,0 ; 6,0)$ \\
\hline & 29 & -2 & 233 & 16 & $\begin{aligned} & 7 \quad(7,0 ; 4,0 ; 3,5 ; 2,0 ; \\
&2,0 ; 1,5 ; 1,5)\end{aligned}$ \\
\hline & & -1 & 220 & 16 & $\begin{array}{l}8(14,0 ; 13,5 ; 8,0 ; 5,0 ; \\
5,0 ; 3,5 ; 1,5 ; 1,5)\end{array}$ \\
\hline & 58 & -1 & 241 & 15 & $3(6,0 ; 3,5 ; 3,5)$ \\
\hline
\end{tabular}


TABELA 21 - Características morfolōgicas das plantas de cana-deaçūcar, colhidas aos 165 dias.

\begin{tabular}{|c|c|c|c|c|}
\hline Trat. & Plantas & $\begin{array}{l}\text { altura } \\
\text { (cm) }\end{array}$ & $\begin{array}{l}\text { no de } \\
\text { internós }\end{array}$ & $\begin{array}{l}\text { no de } \\
\text { perfilhos }\end{array}$ \\
\hline \multirow{4}{*}{$k_{1}$} & $8-1$ & 96 & 13 & -- \\
\hline & $8-2$ & 96 & & -- \\
\hline & $54-2$ & 103 & 16 & - \\
\hline & $59-2$ & 110 & 15 & -- \\
\hline \multirow{4}{*}{$\mathrm{K}_{2}$} & $67-1$ & 224 & 14 & $4(9,0 ; 9,5 ; 4,5 ; 2,0)$ \\
\hline & $67-2$ & 231 & 14 & $\begin{array}{c}5(10,0 ; 7,0 ; 7,0 ; 6,0 ; \\
3,0)\end{array}$ \\
\hline & $9-1$ & 220 & 14 & $3(6,0 ; 8,0 ; 9,5)$ \\
\hline & $9-2$ & 223 & 14 & $3(6,5 ; 4,0 ; 3,0)$ \\
\hline \multirow{4}{*}{$\mathrm{K}_{3}$} & $20-2$ & 231 & 16 & $4(6,5 ; 7,0 ; 3,5 ; 4,0)$ \\
\hline & $10-2$ & 245 & 15 & $2(6,0 ; 2,5)$ \\
\hline & $3-2$ & 251 & 16 & $3(6,0 ; 5,0 ; 3,5)$ \\
\hline & $68-2$ & 240 & 15 & $\begin{array}{rr}6 \quad(6,0 ; 4,0 ; 2,0 ; 2,0 ; \\
\quad 2,5 ; 1,5)\end{array}$ \\
\hline \multirow{4}{*}{$\mathrm{K}_{4}$} & $11-1$ & 229 & 16 & $3(4,0 ; 7,0 ; 2,5)$ \\
\hline & $4-2$ & 230 & 14 & $3(6,0 ; 9,0 ; 7,0)$ \\
\hline & $23-1$ & 236 & 17 & $\begin{array}{l}6 \quad(7,5 ; 6,5 ; 3,0 ; 3,0 ; \\
3,0 ; 1,5)\end{array}$ \\
\hline & $23-2$ & 235 & 17 & $3(17,0 ; 15,0 ; 1,0)$ \\
\hline \multirow{4}{*}{$K_{5}$} & $65-1$ & 230 & 16 & $3(19,0 ; 3,0 ; 2,5)$ \\
\hline & $65-2$ & 247 & 16 & $3(5,5 ; 4,0 ; 3,0)$ \\
\hline & $58-2$ & 226 & 14 & $3(4,5 ; 3,0 ; 2,5)$ \\
\hline & $36-2$ & 245 & 16 & $\begin{array}{rr}10 \quad(4,5 ; 5,0 ; 2,0 ; 7,0 ; \\
6,0 ; 5,5 ; 7,5 ; 4,0 ; \\
\quad 3,5 ; 3,0) & \end{array}$ \\
\hline
\end{tabular}


TABELA 22 - Características morfológicas das plantas de cana-deaçūcar, colhidas aos 180 dias.

\begin{tabular}{|c|c|c|c|c|c|}
\hline Trat. & & antas & $\begin{array}{l}\text { aitura } \\
\text { (cm) }\end{array}$ & $\begin{array}{l}\text { no de } \\
\text { internós }\end{array}$ & $\begin{array}{c}\text { no de } \\
\text { perfilhos }\end{array}$ \\
\hline \multirow{4}{*}{$k_{1}$} & 1 & -2 & 127 & 15 & -- \\
\hline & & -2 & 138 & 14 & -- \\
\hline & & -1 & 96 & 26 & - \\
\hline & 37 & -2 & 103 & 15 & -- \\
\hline \multirow{4}{*}{$\mathrm{K}_{2}$} & 31 & -1 & 248 & 15 & $\begin{aligned} 6(5,0 ; & 5,5 ; 7,0 ; 4,0 ; \\
3,0 ; 2,0) & \end{aligned}$ \\
\hline & 31 & -2 & 241 & 16 & $4(4,0 ; 8,0 ; 5,0 ; 5,0)$ \\
\hline & 38 & -1 & 233 & 16 & $\begin{array}{l}6 \quad(8,0 ; 9,0 ; 3,5 ; 4,0 ; \\
\quad 2,0 ; 2,0)\end{array}$ \\
\hline & 38 & -2 & 231 & 16 & $\begin{array}{c}5(10,0 ; 4,0 ; 8,0 ; 4,0 ; \\
3,0)\end{array}$ \\
\hline \multirow{4}{*}{$k_{3}$} & 15 & -1 & 239 & 16 & $\begin{array}{c}6(17,0 ; 4,5 ; 4,0 ; 3,0 ; \\
3,0 ; 2,0)\end{array}$ \\
\hline & 15 & -2 & 249 & 16 & $4(8,0 ; 8,5 ; 8,0 ; 7,0)$ \\
\hline & 22 & -1 & 254 & 17 & $2(13,0 ; 7,5)$ \\
\hline & 22 & -2 & 249 & 16 & $4(9,0 ; 9,0 ; 4,0 ; 2,0)$ \\
\hline \multirow{4}{*}{$K_{4}$} & 16 & -1 & 269 & 17 & $3(10,0 ; 11,0 ; 8,0)$ \\
\hline & 16 & -2 & 267 & 16 & $3(11,0 ; 15,0 ; 3,0)$ \\
\hline & 69 & -1 & 238 & 15 & $3(8,0 ; 4,0 ; 2,0)$ \\
\hline & 69 & -2 & 239 & 17 & $3(8,0 ; 3,0 ; 7,0)$ \\
\hline \multirow{4}{*}{$\mathrm{K}_{5}$} & 17 & -1 & 266 & 16 & $3(8,0 ; 4,0 ; 2,0)$ \\
\hline & 17 & -2 & 273 & 16 & $3(8,0 ; 3,0 ; 7,0)$ \\
\hline & 24 & -1 & 249 & 17 & $4(12,5 ; 8,0 ; 6,0 ; 3,0)$ \\
\hline & 24 & -2 & 242 & 16 & $4(7,5 ; 9,0 ; 4,0 ; 3,5)$ \\
\hline
\end{tabular}


TABEIA 23 - Atividade de invertase ácida e alcalina em extrato bruto de limbo foliar e bainha de cana-de-açūcar, conduzidas em solução nutritiva contendo 5 concen traçōes de potássio, aos 90 dias de idade.

\begin{tabular}{|c|c|c|c|c|c|}
\hline \multirow{3}{*}{ Trat. } & \multirow{3}{*}{ Plantas } & \multicolumn{2}{|c|}{ Limbo Foliar } & \multicolumn{2}{|c|}{ Bainha } \\
\hline & & \multicolumn{2}{|c|}{ Invertases } & \multicolumn{2}{|c|}{ Invertases } \\
\hline & & alcalina & ácida & alcalina & ácida \\
\hline \multirow{4}{*}{$\mathrm{k}_{1}$} & $35-1$ & -- & 0,055 & 0,505 & 0,410 \\
\hline & $35-2$ & -- & 0,029 & 0,380 & 0,427 \\
\hline & $13-1$ & 0,091 & 0,021 & 0,430 & 0,350 \\
\hline & $13-2$ & 0,103 & 0,022 & 0,491 & 0,381 \\
\hline \multirow{6}{*}{$\mathrm{k}_{2}$} & Média & 0,097 & 0,032 & 0,451 & 0,392 \\
\hline & $26-1$ & 0,135 & 0,108 & 0,006 & ND. \\
\hline & $26-2$ & 0,146 & 0,117 & 0,015 & 0,005 \\
\hline & $19-1$ & 0,176 & 0,144 & 0,029 & ND \\
\hline & $19-2$ & 0,178 & 0,127 & 0,037 & 0,010 \\
\hline & Média & 0,159 & 0,124 & 0,022 & 0,004 \\
\hline \multirow{5}{*}{$\mathrm{K}_{3}$} & $49-1$ & 0,090 & 0,078 & 0,015 & 0,000 \\
\hline & $49-2$ & 0,147 & 0,118 & 0,075 & 0,070 \\
\hline & $56 \cdots 1$ & 0,107 & 0,097 & 0,096 & 0,090 \\
\hline & $56-2$ & 0,059 & 0,063 & 0,053 & $0,05.5$ \\
\hline & Média & 0,100 & 0,301 & 0,060 & 0,053 \\
\hline \multirow{4}{*}{$\mathrm{K}_{4}$} & $40-1$ & 0,195 & 0,146 & 0,019 & 0,015 \\
\hline & $40-2$ & 0,259 & 0,176 & 0,027 & 0,022 \\
\hline & $62-1$ & 0,252 & 0,202 & 0,049 & 0,043 \\
\hline & $62-2$ & 0,112 & 0,081 & 0,033 & 0,035 \\
\hline \multirow{6}{*}{$\mathrm{K}_{5}$} & Média & 0,204 & 0,151 & 0,032 & 0,028 \\
\hline & $53-1$ & 0,041 & 0,036 & 0,150 & 0,165 \\
\hline & $53-2$ & 0,037 & 0,050 & 0,091 & 0,041 \\
\hline & $63-1$ & 0,053 & 0,035 & 0,036 & 0,090 \\
\hline & $63-2$ & 0,040 & 0,047 & 0,075 & 0,070 \\
\hline & Média & 0,043 & 0,042 & $0 ; 088$ & 0,091 \\
\hline
\end{tabular}

a/ Atividade expressa em (mg de sacarose I nvertida/mg de proteĺnas/hora). ND $=$ Não Detectado. 
TABELA 24 - Atividade de invertases acida e alcalina em extrato bruto de limbo foliar e bainha de cana-de - açūcar, conduzidas em solução nutritiva contendo 5 concen trações de potássio, aos 105 dias de idade.

\begin{tabular}{|c|c|c|c|c|c|}
\hline \multirow{3}{*}{ Trat. } & \multirow{3}{*}{ Plantas } & \multicolumn{2}{|c|}{ Limbo Foliar } & \multicolumn{2}{|c|}{ Bainha } \\
\hline & & \multicolumn{2}{|c|}{ Invertases } & \multicolumn{2}{|c|}{ Invertases } \\
\hline & & alcalina & ácida & alcalina & ácida \\
\hline \multirow{5}{*}{$x_{2}$} & $47-1$ & 0,147 & 0,026 & 1,447 & 1,480 \\
\hline & $47-2$ & 0,186 & 0,053 & 1,126 & 0,975 \\
\hline & $42-1 \ldots$ & 0,163 & 0,045 & 1,286 & 0,778 \\
\hline & $42-2$ & $.0,167$ & 0,043 & 1,310 & 0,191 \\
\hline & Média & 0,166 & 0,042 & $1 ., 292$ & 1,801 \\
\hline \multirow{5}{*}{$\mathrm{K}_{2}$} & $43-1$ & 0,122 & 0,050 & 0,798 & 0,804 \\
\hline & $43-2$ & 0,045 & 0,056 & 0,510 & 0,501 \\
\hline & $50-1$ & 0,121 & 0,043 & 0,389 & 0,473 \\
\hline & $50-2$ & 0,128 & 0,065 & 0,713 & 0,691 \\
\hline & Média & 0,104 & 0,053 & 0,602 & 0,617 \\
\hline \multirow{5}{*}{$\mathrm{k}_{3}$} & $44-1$ & 0,087 & 0.076 & 0,100 & 0,179 \\
\hline & $44-2$ & 0,224 & 0,136 & 0,372 & 0.291 \\
\hline & $51-1$ & 0,151 & 0,136 & 0,313 & 0,170 \\
\hline & $68-2$ & 0,212 & 0,157 & 0,405 & 0,200 \\
\hline & Média & 0,168 & 0,128 & 0,297 & 0,210 \\
\hline \multirow{5}{*}{$\mathrm{K}_{4}$} & $28-1$ & 0,220 & 0,112 & 0,115 & 0,128 \\
\hline & $28-2$ & 0,123 & 0,126 & 0,321 & 0,290 \\
\hline & $45-1$ & 0,223 & 0,064 & 0,457 & 0,225 \\
\hline & $45-2$ & 0,114 & 0,100 & 0,195 & 0,179 \\
\hline & Média & 0,170 & 0,100 & 0,272 & 0,205 \\
\hline \multirow{5}{*}{$k_{5}$} & $41-1$ & 0,215 & 0,114 & 0,275 & 0,236 \\
\hline & $41-2$ & 0,307 & 0,133 & 0,230 & 0.251 \\
\hline & $34-1$ & 0,276 & 0,151 & 0,264 & 0,172 \\
\hline & $34-2$ & 0,273 & 0,120 & 0,299 & 0,172 \\
\hline & Média & 0,261 & 0,129 & 0,242 & 0,208 \\
\hline
\end{tabular}


TABELA 25 - Atividade de invertases âcida e alcalina em extra to bruto de limbo foliar e bainha de cana-de - açū car, conduzidas em solução nutritiva contendo 5 concentrações de potássio, aos 120 dias de idade.

\begin{tabular}{|c|c|c|c|c|c|}
\hline \multirow{3}{*}{ Trat. } & \multirow{3}{*}{ Plantas } & \multirow{2}{*}{\multicolumn{2}{|c|}{$\begin{array}{c}\text { Limbo Foliar } \\
\text { Invertases }\end{array}$}} & \multirow{2}{*}{\multicolumn{2}{|c|}{$\begin{array}{l}\text { Bainha } \\
\text { Invertases }\end{array}$}} \\
\hline & & & & & \\
\hline & & alcalina & ácida & alcalina & ácida \\
\hline \multirow{5}{*}{$\mathrm{k}_{1}$} & $18-1$ & 0,045 & 0,403 & 0,155 & 0,086 \\
\hline & $18-2$ & 0,401 & 0,248 & 0,317 & 0,137 \\
\hline & $25-1$ & 0,222 & 0,034 & 0,315 & 0,125 \\
\hline & $25=2$ & 0,199 & 0,030 & 0,123 & 0,191 \\
\hline & Média & 0,217 & 0,179 & 0,227 & 0,135 \\
\hline \multirow{5}{*}{$\mathrm{K}_{2}$} & $48-1$ & 0,097 & 0,068 & 0,569 & 0,404 \\
\hline & $48-2$ & 0,062 & 0,072 & 0,431 & 0,525 \\
\hline & $55-1$ & 0,061 & 0,020 & 0,426 & 0,654 \\
\hline & $55-2$ & 0,084 & 0,019 & 0,397 & 0,455 \\
\hline & Média & 0,076 & 0,045 & 0,456 & 0,509 \\
\hline \multirow{5}{*}{$R_{3}$} & $32-1$ & 0,053 & 0,038 & 0,200 & 0,204 \\
\hline & $32-2$ & 0,054 & 0,045 & 0,321 & 0.450 \\
\hline & $39-1$ & 0,035 & 0,034 & 0,494 & 0,445 \\
\hline & $39-2$ & 0.035 & 0,072 & 0,297 & 0,199 \\
\hline & Média & 0,044 & 0,047 & 0,328 & 0,324 \\
\hline \multirow{5}{*}{$k_{4}$} & $21-1$ & 0,078 & 0,061 & 0,590 & 0,514 \\
\hline & $21-2$ & 0,199 & 0,109 & 0,325 & 0,223 \\
\hline & $33-1$ & 0,099 & 0,086 & 0,147 & 0,132 \\
\hline & $33-2$ & 0,157 & 0,102 & 0,378 & 0,291 \\
\hline & Média & 0,133 & 0,089 & 0,360 & 0,290 \\
\hline \multirow{5}{*}{$\mathrm{K}_{5}$} & $12-1$ & 0,095 & 0,103 & 0,153 & 0,098 \\
\hline & $12-2$ & 0,066 & 0,066 & 0,197 & $0,13.1$ \\
\hline & $46-1$ & 0,067 & 0.037 & 0,266 & 0,260 \\
\hline & $46-2$ & 0,084 & 0,034 & 0,205 & 0,210 \\
\hline & Média & 0,078 & 0,060 & 0.205 & 0,174 \\
\hline
\end{tabular}


TABELA 26 - Atividade de invertases ácida e alcalina em extra to bruto de limbo foliar e bainha de cana-de - açū car, conduzidas em solução nutritiva contenđo 5 concentrações de potássio, aos 135 dias de idade.

\begin{tabular}{|c|c|c|c|c|c|}
\hline \multirow{3}{*}{ Trat. } & \multirow{3}{*}{ Plantas } & \multirow{2}{*}{\multicolumn{2}{|c|}{$\begin{array}{c}\text { Limbo Foliar } \\
\text { Invertases }\end{array}$}} & \multirow{2}{*}{\multicolumn{2}{|c|}{$\frac{\text { Bainha }}{\text { Invertases }}$}} \\
\hline & & & & & \\
\hline & & alcalina & ácida & alcalina & ácida \\
\hline \multirow{5}{*}{$\mathrm{k}_{1}$} & $6-1$ & 0,207 & 0,133 & 0,107 & 0,139 \\
\hline & $6=-2$ & 0,145 & 0,096 & 0,225 & 0,197 \\
\hline & $66-1$ & 0,158 & 0,119 & 0,315 & 0,329 \\
\hline & $66-2$ & 0,219 & 0,147 & 0,310 & 0,271 \\
\hline & Média & 0,182 & 0,124 & 0,239 & 0,234 \\
\hline \multirow{5}{*}{$\mathrm{K}_{2}$} & $7-1$ & 0,141 & 0,064 & 0,134 & 0,172 \\
\hline & $7-2$ & 0,110 & 0,076 & 0,201 & 0,129 \\
\hline & $14-1$ & 0,127 & 0,079 & 0,267 & 0,141 \\
\hline & $14-2$ & 0,100 & 0,051 & 0,201 & 0,117 \\
\hline & Média & 0,119 & $0,06 ?$ & 0,201 & 0,180 \\
\hline \multirow{5}{*}{$\mathrm{K}_{3}$} & $3-1$ & 0,147 & 0,046 & 0,559 & 0,352 \\
\hline & $51-2$ & 0,147 & 0,076 & 0,351 & 0,275 \\
\hline & $61-1$ & 0,104 & 0,076 & 0,127 & 0,153 \\
\hline & $61-2$ & 0,120 & 0,101 & 0,410 & 0,210 \\
\hline & Média & 0,129 & 0,074 & 0,362 & 0,247 \\
\hline \multirow{5}{*}{$\mathrm{K}_{4}$} & $45-2$ & 0,125 & 0,083 & 0,011 & 0,014 \\
\hline & $52-2$ & 0,053 & 0,060 & 0,107 & 0,090 \\
\hline & $64-1$ & 0,193 & 0,261 & 0,061 & 0,058 \\
\hline & $64-2$ & 0,173 & 0,176 & 0,095 & 0,071 \\
\hline & MÉdia & 0,136 & 0,145 & 0,068 & 0,058 \\
\hline \multirow{5}{*}{$k_{5}$} & $70-1$ & 0,125 & 0,226 & 0,017 & 0,008 \\
\hline & $70-2$ & 0,033 & 0,056 & 0,009 & 0,003 \\
\hline & $5-1$ & 0,038 & 0,027 & 0,013 & ND \\
\hline & $5-2$ & 0,054 & 0,030 & 0,018 & 0,007 \\
\hline & Média & 0,062 & 0,084 & 0,014 & 0,004 \\
\hline
\end{tabular}


TABEIA 27 - Atividade de invertases alcalina e ácida em extra to bruto de limbo foliar e bainha de cana-de - açū car, conduzidas em solução nutritiva contendo 5 concentraçc̃es de potássio, aoś 150 dias de idade.

\begin{tabular}{|c|c|c|c|c|c|}
\hline \multirow{3}{*}{ Trat. } & \multirow{3}{*}{ Plantas } & \multirow{2}{*}{\multicolumn{2}{|c|}{ Limbo Foliar }} & \multicolumn{2}{|c|}{ Bainha } \\
\hline & & & & \multicolumn{2}{|c|}{ Invertases } \\
\hline & & alcalina & $a ̈ c i d a$ & alcalina & áci da \\
\hline \multirow{5}{*}{$\mathrm{k}_{1}$} & $59-1$ & 0,047 & 0,036 & 0,186 & 0,137 \\
\hline & $30-1$ & 0,082 & 0,052 & 0,195 & 0,121 \\
\hline & $1=-\bar{I}$ & 0,111 & 0,060 & 0,205 & 0,181 \\
\hline & $54-1$ & 0,048 & 0,011 & 0,217 & 0,179 \\
\hline & Média' & 0,072 & 0,039 & 0,201 & 0,154 \\
\hline \multirow{5}{*}{$\mathrm{K}_{2}$} & $2-1$ & 0,108 & 0,035 & 0,073 & 0,015 \\
\hline & $2-2$ & 0,190 & 0,039 & 0,271 & 0,091 \\
\hline & $60-1$ & 0,035 & 0,037 & 0,253 & 0,068 \\
\hline & $60-2$ & 0,079 & 0,032 & 0,121 & 0,036 \\
\hline & Média & 0,103 & 0,035 & 0,179 & 0,052 \\
\hline \multirow{5}{*}{$x_{3}$} & $10-1$ & 0,083 & 0,027 & 0,336 & 0,041 \\
\hline & $27-1$ & 0,116 & 0,066 & 0,291 & 0,025 \\
\hline & $27-2$ & 0,109 & 0,049 & 0,464 & 0,073 \\
\hline & $20-1$ & 0,126 & 0,028 & 0,356 & 0,059 \\
\hline & Média & 0,108 & 0,042 & 0,362 & 0,049 \\
\hline \multirow{4}{*}{$\mathrm{K}_{4}$} & $57-1$ & 0,137 & 0,028 & 0,093 & 0,018 \\
\hline & $57-2$ & 0,142 & 0,052 & 0,213 & 0,017 \\
\hline & $4-1$ & $0,0.42$ & 0,023 & 0,131 & 0,100 \\
\hline & $11-2$ & 0,186 & 0,044 & 0,175 & 0,026 \\
\hline \multirow{6}{*}{$\mathrm{K}_{5}$} & Média & 0,126 & 0,036 & 0,153 & 0,040 \\
\hline & $29-1$ & 0,128 & 0,044 & 0,294 & 0,019 \\
\hline & $29-2$ & 0,063 & 0,063 & 0,177 & 0,027 \\
\hline & $36-1$ & 0,153 & 0,050 & 0,050 & 0,007 \\
\hline & $36-2$ & 0,104 & 0,054 & 0,151 & 0,039 \\
\hline & Média & 0,112 & 0,052 & 0,143 & 0,023 \\
\hline
\end{tabular}


TABEIA 28 - Atividade de invertases alcalina e ācida em extra to bruto de iimbo foliar e bainha de cana-de - açü car, conduzidas em soluçäo nutrïtiva contendo 5 concentrações de potássio, aos $\mathbf{1 6 5}$ dias de idade.

\begin{tabular}{|c|c|c|c|c|c|}
\hline \multirow{3}{*}{ Trat. } & \multirow{3}{*}{ Plantas } & \multirow{2}{*}{\multicolumn{2}{|c|}{$\begin{array}{c}\text { Limbo Foliar } \\
\text { Invertases }\end{array}$}} & \multirow{2}{*}{\multicolumn{2}{|c|}{$\frac{\text { Bainha }}{\text { Invertases }}$}} \\
\hline & & & & & \\
\hline & & alcalina & ácida & al calüna & ácida \\
\hline \multirow{5}{*}{$k_{1}$} & $8-1$ & $0,540^{\circ}$ & 0,392 & 0,9188 & 0,128 \\
\hline & $8=-\overline{2}$ & 0,265 & 0,071 & $0,4 \mathrm{BI}$ & 0,115 \\
\hline & $54-2$ & 0,196 & 0,080 & 0,353 & 0,139 \\
\hline & $59-2$ & 0,439 & 0,327 & 0,3277 & 0,123 \\
\hline & Média & 0,360 & 0,217 & 0,507 & 0,126 \\
\hline \multirow{5}{*}{$\mathrm{K}_{2}$} & $67-1$ & 0,099 & 0,078 & 0,120 & 0,018 \\
\hline & $67-2$ & 0,118 & 0,042 & $0,17 \mathbb{1}$ & 0,061 \\
\hline & $9-1$ & 0,094 & 0,053 & 0,156 & 0,081 \\
\hline & $9-2$ & 0,104 & 0,056 & $0,0.97 \pi$ & 0,033 \\
\hline & Média & 0,103 & 0,057 & 0,133 & 0,048 \\
\hline \multirow{5}{*}{$\mathrm{K}_{3}$} & $20-2$ & 0,158 & 0,087 & 0,537 & 0,079 \\
\hline & $10-2$ & 0,091 & 0,053 & 0,497 & 0,075 \\
\hline & $3-2$ & 0,091 & 0,039 & 0,531 & 0,031 \\
\hline & $68-2$ & 0,049 & 0,022 & 0,58 & 0,093 \\
\hline & Média & 0,097 & 0,050 & $0,5 Z 7$ & 0,069 \\
\hline \multirow{5}{*}{$\mathrm{K}_{4}$} & $11-1$ & 0,076 & 0,019 & $0,0.93$ & 0,018 \\
\hline & $4-2$ & 0,128 & 0,058 & 0,213 & 0,017 \\
\hline & $23-1$ & 0,103 & 0,069 & $0,13 I$ & 0,100 \\
\hline & $23-2$ & 0,087 & 0,072 & 0,175 & 0,026 \\
\hline & Média & 0,098 & 0,054 & 0,153 & 0,040 \\
\hline \multirow{5}{*}{$k_{5}$} & $65-1$ & 0,078 & 0,051 & 0,104 & 0,019 \\
\hline & $65-2$ & 0.034 & 0,031 & 0,177 & 0,027 . \\
\hline & $58-2$ & 0,097 & 0,052 & 0,050 & 0,007 \\
\hline & $36-2$ & 0,071 & 0,046 & $0,13 \mathrm{I}$ & 0,039 \\
\hline & Média & 0,070 & 0,045 & 0,153 & 0,023 \\
\hline
\end{tabular}


TABELA 29 - Atividade de invertases alcalina e ácida em extra to bruto de Iimbo foliar e bainha de cana-de - açū car, conduzidas em solução nutritiva contendo 5 concentrações de potássio, aos 180 dias de idade.

\begin{tabular}{|c|c|c|c|c|c|}
\hline \multirow{3}{*}{ Trat. } & \multirow{3}{*}{ Plantas } & \multicolumn{2}{|c|}{ Limbo Foliar } & \multicolumn{2}{|c|}{ Bainha } \\
\hline & & \multicolumn{2}{|c|}{ Invertases } & \multicolumn{2}{|c|}{ Invertases } \\
\hline & & alcalina & äcida & alcalina. & ăcida \\
\hline \multirow{5}{*}{$k_{1}$} & $1-2$ & 0,130 & 0,109 & 0,346 & 0,126 \\
\hline & $30-2$ & 0,228 & 0,120 & 0,571 & 0,097 \\
\hline & $37 \cdots--1$ & 0,154 & 0,133 & 0,777 & 0,190 \\
\hline & $37-2$ & 0,137 & 0,077 & 0,415 & 0,110 \\
\hline & Média & 0,155 & 0,109 & 0,527 & 0,131 \\
\hline \multirow{5}{*}{$\mathrm{K}_{2}$} & $31-1$ & 0,112 & 0,078 & 0,112 & 0,080 \\
\hline & $31-2$ & 0.053 & 0,031 & 0,210 & 0,037 \\
\hline & $38-1$ & 0,059 & 0,043 & 0,146 & 0,041 \\
\hline & $38-2$ & 0,082 & 0,047 & 0,193 & 0.075 \\
\hline & Média & 0.076 & 0,049 & 0,165 & 0,058 \\
\hline \multirow{5}{*}{$x_{3}$} & $15-1$ & 0,042 & 0,032 & 0,127 & 0,023 \\
\hline & $15-2$ & 0,044 & 0,022 & 0,191 & 0,031 \\
\hline & $22-1$ & 0,056 & 0,034 & 0,339 & 0,197 \\
\hline & $22-2$ & 0,031 & 0,029 & 0,203 & 0,107 \\
\hline & Média & 0,043 & 0,029 & 0,215 & 0,089 \\
\hline \multirow{5}{*}{$k_{4}$} & $16-1$ & 0.027 & 0,028 & 0,457 & 0,102 \\
\hline & $16-2$ & 0,044 & 0,027 & 0,297 & 0,013 \\
\hline & $69-1$ & 0,046 & 0,054 & 0,270 & 0,035 \\
\hline & $69-2$ & 0,041 & 0,033 & 0,305 & 0,037 \\
\hline & Média & 0,039 & 0,035 & 0,332 & 0,046 \\
\hline \multirow{5}{*}{$k_{5}$} & $17-1$ & 0.169 & 0,062 & 0,200 & 0,130 \\
\hline & $17-2$ & 0,110 & 0.040 & 0,123 & 0,031 \\
\hline & $24-1$ & 0.075 & 0,033 & 0,146 & 0,029 \\
\hline & $24-2$ & 0.095 & 0,063 & 0,167 & 0,031 \\
\hline & Média & 0,112 & 0,049 & 0,159 & 0,055 \\
\hline
\end{tabular}


TABELA 30 - Atividade de sacarose sintetase em extrato bruto de bainha de cana-de-açứcar, conduzida em solução nutritiva contendo 5 concentrações de potássio, dos 90 aos 180 dias.

\begin{tabular}{|c|c|c|c|c|c|c|c|}
\hline \multirow{3}{*}{ Epoca } & \multirow{3}{*}{ Dias } & \multirow{3}{*}{ Repetição } & \multicolumn{4}{|c|}{ Atividade de S.S.at } & \\
\hline & & & \multicolumn{5}{|c|}{ Tratamentos } \\
\hline & & & $\mathrm{K}_{1}$ & $\mathrm{~K}_{2}$ & $\mathrm{~K}_{3}$ & $\mathrm{~K}_{4}$ & $\mathrm{~K}_{5}$ \\
\hline \multirow{3}{*}{$E_{1}$} & \multirow{3}{*}{20} & 1 & 2,187 & 0,243 & 0,190 & 0,222 & 0,131 \\
\hline & & 2 & 1,550 & 0,386 & 0,208 & 0,341 & 0,109 \\
\hline & & Média & 1,868 & 0,314 & 0,199 & 0,281 & 0,120 \\
\hline \multirow{3}{*}{$\mathrm{E}_{2}$} & \multirow{3}{*}{105} & 1 & 2,302 & 1,439 & 0,598 & 0,131 & 0,911 \\
\hline & & 2 & 1,772 & 1,050 & 0,725 & 0,559 & 0,817 \\
\hline & & Média & 2,037 & 1,244 & 0,661 & 0,345 & 0,864 \\
\hline \multirow{3}{*}{$\mathrm{E}_{3}$} & \multirow{3}{*}{120} & 1 & 1,303 & 1,178 & 0,843 & 0,741 & 0,971 \\
\hline & & 2 & 0,932 & 0,937 & 1,003 & 1,200 & 0,887 \\
\hline & & Média & 1,117 & 1,057 & 0,923 & 0,970 & 0,929 \\
\hline \multirow{3}{*}{$\Sigma_{4}$} & \multirow{3}{*}{135} & 1 & 0,578 & 0,226 & 0,393 & 0,126 & 0,103 \\
\hline & & 2 & 0,807 & 0,215 & 0,174 & 0,567 & 0,195 \\
\hline & & Média & 0,692 & 0,220 & 0,283 & 0,346 & 0,149 \\
\hline \multirow{3}{*}{$E_{5}$} & \multirow{3}{*}{150} & 1 & 1,231 & 0,592 & 1,012 & 1,104 & 0,569 \\
\hline & & 2 & 1,053 & 0,520 & 1,302 & 1,132 & 0,654 \\
\hline & & Média & 0,142 & 0,556 & 1,157 & 1,268 & 0,611 \\
\hline \multirow{3}{*}{$E_{6}$} & \multirow{3}{*}{165} & 1 & 0,741 & 0,543 & 1,541 & 2,187 & 0,600 \\
\hline & & 2 & 1,671 & 0,337 & 0,931 & 0,975 & 0,592 \\
\hline & & Média & 1,206 & 0,440 & 1,236 & 1,581 & 0,596 \\
\hline \multirow{3}{*}{$\mathrm{E}_{7}$} & \multirow{3}{*}{180} & 1 & 1,153 & 0,814 & 0,930 & 0,698 & 0,316 \\
\hline & & 2 & 0,556 & 0,465 & 0,761 & $0,610$. & 0,218 \\
\hline & & Média & 0,854 & 0,640 & 0,845 & 0,654 & 0,267 \\
\hline
\end{tabular}

a/Atividade expressa em $\mu \mathrm{M}$ sacarose sintetizada/mg proteínas/ /hora. 
TABELA 31 - Análises químicas efetuadas em limbo foliar de fo lhas 3: e 4: de cana-de-açūcar saccharum spp., cv. NA56-79, cultivadas em solução nutritiva contendo 5 concentrações de potássio, desenvolvidas em con dições de casa de vegetação aos 90 dias. ( 8 p/p na matéria seca liofilizada).

\begin{tabular}{|c|c|c|c|c|c|c|}
\hline Tratamento & Amos tra & $\begin{array}{l}K \\
(8)\end{array}$ & $\begin{array}{l}\mathrm{Na} \\
(\mathrm{z})\end{array}$ & $\begin{array}{c}\mathrm{N}-\alpha \mathrm{NH}_{2} \\
(\mathrm{z})\end{array}$ & $\begin{array}{l}\text { Proteinas } \\
\text { totais } \\
(8)\end{array}$ & $\begin{array}{c}\text { N-Total } \\
\text { (8) }\end{array}$ \\
\hline \multirow{5}{*}{$\mathrm{x}_{1}$} & $35-1$ & 0,30 & 0,006 & 0,37 & 22,9 & 2,30 \\
\hline & $35-2$ & 0,20 & 0,015 & 0,59 & 22,9 & 2,14 \\
\hline & $13-1$ & 0,30 & 0,019 & 0,48 & 21,9 & 2,47 \\
\hline & 13,2 & 0,20 & 0,023 & 0,45 & 28,9 & 2,88 \\
\hline & Média & 0,25 & 0,016 & 0,47 & 24,1 & 2,44 \\
\hline \multirow{5}{*}{$x_{2}$} & $26-1$ & 1,00 & 0,013 & 0,32 & 27,5 & 1,81 \\
\hline & $26-2$ & 0,35 & 0,006 & 0,35 & 29,9 & 2,37 \\
\hline & $19-1$ & 0,95 & 0,010 & 0,53 & 28,9 & 2,79 \\
\hline & $19-2$ & 0,70 & 0,018 . & 0,37 & 26,9 & 2,38 \\
\hline & Mēdia & 0,75 & 0,012 & 0,39 & 28,3 & 2,34 \\
\hline \multirow{5}{*}{$\mathrm{k}_{3}$} & $49-1$ & 1,90 & 0,009 & 0,37 & 28,7 & 2,11 \\
\hline & 49-2 & 2,15 & 0,025 & 0,41 & 27,5 & 2,22 \\
\hline & $56-1$ & 2,10 & 0,021 & 0,51 & 22,8 & 1,89 \\
\hline & $56-2$ & 2,35 & 0,026 & 0,51 & 31,9 & 1,47 \\
\hline & Média & 2,12 & 0,020 & 0,45 & 27,7 & 1,92 \\
\hline \multirow{5}{*}{$K_{4}$} & $40-1$ & 2,20 & 0,021 & 0,54 & 33,9 & 2,47 \\
\hline & $40-2$ & 2,00 & 0,015 & 0,54 & 39,9 & 3,02 \\
\hline & $62-1$ & 1,55 & 0,017 & 0,24 & 27,9 & 2,22 \\
\hline & $62-2$ & 1,70 & 0,014 & 0,28 & 25,9 & 1,55 \\
\hline & Média & 1,86 & 0,017 & 0,40 & 31,9 & 2,31 \\
\hline \multirow{5}{*}{$\mathrm{x}_{5}$} & $53-1$ & 2,10 & 0,024 & 0,0 & 20,3 & 1,64 \\
\hline & $53-2$ & 2,25 & 0,014 & 0,51 & 25,7 & 3,05 \\
\hline & $63-1$ & 1,80 & 0,033 & 0,69 & 26,9 & 2,14 \\
\hline & $63-2$ & 0,95 & 0,007 & 0,60 & 23,9 & 1,31 \\
\hline & Méđia & 1,77 & 0,019 & 0,60 & 24,3 & 2,03 \\
\hline
\end{tabular}


TABEIA 32 - Anālises químicas efetuadas em limbo foliar de fo Ihas $3^{a} \cdot$ e $4^{a} \cdot$ de cana-de-açücar saccharum spp., cv. NA56-79, cultivadas em solução nutritiva contendo 5 concentrações de potássio, desenvolvidas em con dições de casa de vegetação aos 120 dias. (\% p/p na matēria seca liofilizada).

\begin{tabular}{|c|c|c|c|c|c|c|}
\hline Tratamento & Amos tra & $\begin{array}{c}K \\
(q)\end{array}$ & $\begin{array}{l}\mathrm{Na} \\
(8)\end{array}$ & $\begin{array}{c}N-\alpha H_{2} \\
(8)\end{array}$ & $\begin{array}{c}\text { Proteinas } \\
\text { totais } \\
(8)\end{array}$ & $\begin{array}{c}\text { N-Total } \\
(8)\end{array}$ \\
\hline & $18-1$ & 0,25 & 0,028 & 1,25 & 14,8 & 2,22 \\
\hline & $18-2$ & 0,05 & $0,03 ?$ & 1,52 & 16,8 & 1,74 \\
\hline \multirow[t]{5}{*}{$\mathrm{K}_{1}$} & $25-1$ & 0,25 & 0,057 & 1,06 & 16,8 & 1,94 \\
\hline & $25-2$ & 0,05 & 0,041 & 0,95 & 18,9 & 1,56 \\
\hline & Média & 0,15 & 0,041 & 1,19 & 16,8 & 1,86 \\
\hline & $48-1$ & 1,60 & 0,060 & 0,49 & 25,9 & 2,44 \\
\hline & $48-2$ & 2,15 & 0,041 & 0,49 & 27,9 & 2,01 \\
\hline \multirow[t]{5}{*}{$\mathrm{x}_{2}$} & $55-1$ & 1,30 & 0,012 & 0,52 & 22,9 & 1,61 \\
\hline & $55-2$ & 1,30 & 0,035 & 0,53 & 22,9 & 1,90 \\
\hline & Média & 1,58 & 0,037 & 0,51 & 24,9 & 1,99 \\
\hline & $32-1$ & 1,50 & 0,028 & 0,39 & 22,9 & 1,74 \\
\hline & $32-2$ & 1,05 & 0,014 & 0,55 & 23,9 & 2,47 \\
\hline \multirow[t]{3}{*}{$\mathrm{k}_{3}$} & $39-1$ & 1,50 & 0,033 & 0,52 & 24,9 & 1,89 \\
\hline & $39-2$ & 1,40 & 0,027 & 0,55 & 21,9 & 1,89 \\
\hline & Médi a & 1,35 & 0,025 & 0,50 & 23,4 & 2,08 \\
\hline \multirow{2}{*}{. } & $21-1$ & 1,70 & 0,031 & 0,44 & 22,9 & 2,55 \\
\hline & $21-2$ & 1,45 & 0,035 & 0,45 & 25,9 & 2,55 \\
\hline \multirow[t]{5}{*}{$x_{4}$} & $31-1$ & 2,00 & 0,022 & 0,45 & 24,9 & 1,89 \\
\hline & $33-2$ & 0,60 & 0,025 & 0,37 & 22,9 & 2,42 \\
\hline & Média & 1,43 & 0,028 & 0,43 & 24,1 & 2,35 \\
\hline & $12-1$ & 1,65 & 0,020 & 0,33 & 24,9 & 2,72 \\
\hline & $12-2$ & 1,50 & 0,012 & 0,43 & 22,9 & 1,97 \\
\hline \multirow[t]{3}{*}{$x_{5}$} & $46-1$ & 1,90 & 0,041 & 0,51 & 20,9 & 2,90 \\
\hline & $46-2$ & 1,45 & 0,059 & 0,49 & 24,9 & 2,30 \\
\hline & Média & 1,62 & 0,033 & 0,44 & 23,4 & 2,47 \\
\hline
\end{tabular}


TABEIA 33 - Análises químicas efetuadas em limbo foliar de fo Ihas 3: e 4: de cana-de-açūcar saccharum spp., cv. NA56-79, cultivadas em solução nutritiva contendo 5 concentrações de potássio, desenvolvidas em con dições de casa de vegetação aos 150 dias. ( $\frac{9}{5} \mathrm{p} / \mathrm{p}$ na matéria seca liofilizada).

\begin{tabular}{|c|c|c|c|c|c|c|}
\hline Tratamento & Amostra & $\begin{array}{l}X \\
(z)\end{array}$ & $\begin{array}{l}\mathrm{Na} \\
(8)\end{array}$ & $\begin{array}{l}N-\alpha H_{2} \\
-(8)\end{array}$ & $\begin{array}{l}\text { Proteinas } \\
\text { totais } \\
(8)\end{array}$ & $\begin{array}{c}\text { N-Total } \\
\text { (s) }\end{array}$ \\
\hline \multirow{5}{*}{$\mathrm{x}_{1}$} & 59-1 & 0,25 & $.0,081$ & 1,15 & 17,9 & 2,27 \\
\hline & $30-1$ & 0,25 & 0,054 & 1,68 & 18,9 & 1,64 \\
\hline & $1-1$ & 0,30 & 0,017 & 0,83 & 24,9 & 1,82 \\
\hline & $54-1$ & 0,40 & 0,069 & 1,20 & 24,9 & 1,95 \\
\hline & Média & 0,30 & 0,055 & 1,21 & 21,6 & 1,92 \\
\hline \multirow{5}{*}{$x_{2}$} & $2-1$ & 1,55 & 0,014 & 0,37 & 26,9 & 2,14 \\
\hline & $2-2$ & 1,10 & 0,027 & 0,43 & 28,9 & 2,22 \\
\hline & $60-1$ & 1,50 & 0,037 & 0,41 & 19,9 & 2,47 \\
\hline & $60-2$ & 0,70 & 0,053 & 0,32 & 24,9 & 2,14 \\
\hline & Mēdia & 1,21 & 0,033 & 0,38 & 24,9 & 2,24 \\
\hline \multirow{5}{*}{$\mathrm{x}_{3}$} & $10-1$ & 1,40 & 0,017 & 0,35 & 24,9 & 2,22 \\
\hline & $27-1$ & 1,10 & 0,026 & 0,5 & 27.9 & 2,14 \\
\hline & $27-2$ & 1,90 & 0,020 & 0,43 & $2 \pi, 9$ & 2,53 \\
\hline & $20-1$ & 1,65 & 0,037 & 0,37 & 28,9 & 2,39 \\
\hline & Média & 1,51 & 0,025 & 0,45 & 27,4 & 2,33 \\
\hline \multirow{5}{*}{$\mathrm{K}_{4}$} & $57-1$ & 1,30 & 0,041 & 0,26 & 25,9 & 2,05 \\
\hline & $57-2$ & 1,15 & 0,039 & 0,32 & 29,9 & 1,81 \\
\hline & $4-1$ & 1,70 & 0,033 & 0,48 & 20,9 & 1,64 \\
\hline & $11-2$ & 1,60 & 0,035 & 0,23 & 18,8 & 3,05 \\
\hline & Média & 1,44 & 0,037 & 0,32 & 23,9 & 2,14 \\
\hline \multirow{5}{*}{$\mathrm{k}_{5}$} & $29-1$ & 1,45 & 0,027 & 0.89 & 19,9 & 1,89 \\
\hline & $29-2$ & 1,65 & 0,035 & 0,65 & 21,9 & 2,65 \\
\hline & $36-1$ & 1,25 & 0,017 & 0,40 & 31,9 & 1,97 \\
\hline & $58-1$ & 1,40 & 0,051 & 0,37 & 28,9 & 2,24 \\
\hline & Mézila & 1,44 & 0,032 & 0,58 & 25,6 & 2,19 \\
\hline
\end{tabular}


TABELA 34 - Análises químicas efetuadas em limbo foliar de fo Ihas 3. e 4? de cana-de-açücar Saccharum spp., cv. NA56-79 , cultivadas em solução nutritiva contendo 5 concentraçōes de potāssio, desenvolvidas em con dições de casa de vegetação aos 180 dias. $(\% \mathrm{p} / \mathrm{p}$ na matéria seca liofilizada).

\begin{tabular}{|c|c|c|c|c|c|c|}
\hline Tratamento & Amostra & $\begin{array}{l}K \\
(8)\end{array}$ & $\begin{array}{l}\mathrm{Na} \\
(8)\end{array}$ & $\begin{array}{c}\mathrm{N}-\alpha \mathrm{NH}_{2} \\
-\quad(z)\end{array}$ & $\begin{array}{c}\text { Proteinas } \\
\text { totais } \\
(8)\end{array}$ & $\begin{array}{c}\text { N-Total } \\
\text { (8) }\end{array}$ \\
\hline \multirow{5}{*}{$k_{1}$} & $1-2$ & 1,35 & 0,037 & 2,02 & 20,9 & 2,06 \\
\hline & $30-2$ & 0,70 & 0,021 & 2,17 & 28,9 & 2,05 \\
\hline & $37-1$ & $0, i 5$ & 0,027 & 1,71 & 19,9 & 1,86 \\
\hline & $37-2$ & 0,05 & 0,019 & 2,00 & 23,9 & 1,79 \\
\hline & Média & 0,56 & 0,026 & 1,97 & 20,9 & 1,94 \\
\hline \multirow{5}{*}{$\mathrm{x}_{2}$} & $31-1$ & 1,15 & 0.006 & 0,49 & 9 & 1,89 \\
\hline & $31-2$ & 0,30 & 0,017 & 0,35 & 21,9 & 9,38 \\
\hline & $38-1$ & 1,50 & 0,018 & 0,32 & 24,9 & 1,72 \\
\hline & $38-2$ & 1,70 & 0,015 & 0,24 & 24,2 & 2,24 \\
\hline & Média & 1,16 & 0,014 & 0,35 & 22,7 & 2,06 \\
\hline \multirow{5}{*}{$\mathrm{x}_{3}$} & $15-1$ & 1,35 & 0,017 & 0,51 & 22,5 & 2,22 \\
\hline & $15-2$ & 1,50 & 0,008 & 0,37 & 24,9 & 3.05 \\
\hline & $22-1$ & 1,65 & 0,014 & 0,35 & 22,9 & 2,05 \\
\hline & $22-2$ & 0,85 & 0,042 & 0,29 & 21,9 & 2,14 \\
\hline & Mëdia & 1,33 & 0,020 & 0,38 & 23,0 & 2,36 \\
\hline \multirow{5}{*}{$K_{4}$} & $16-1$ & 1,50 & 0,085 & 0,11 & 18,8 & 2,01 \\
\hline & $16-2$ & 1,10 & 0,026 & 0,66 & 24,9 & 2,64 \\
\hline & $69-1$ & 1,90 & 0,012 & 0,49 & 22,9 & 2,08 \\
\hline & $69-2$ & 1,10 & 0,014 & 0,31 & 24,8 & 2,14 \\
\hline & Mēdia & 1,40 & 0,034 & 0,46 & 22,8 & 2,22 \\
\hline \multirow{5}{*}{$k_{5}$} & $17-1$ & 2,25 & 0,034 & 0,38 & 16,9 & 2,34 \\
\hline & $17-2$ & 1,65 & 0,065 & 0,69 & 26,9 & 2,72 \\
\hline & $24-i$ & 1,35 & 0,019 & 0,72 & 21,9 & 2,06 \\
\hline & $24-2$ & 1,75 & 0,023 & $0,44$. & 25,9 & 2,57 \\
\hline & Mēdia & 1,75 & 0,035 & 0,61 & 22,9 & 2,43 \\
\hline
\end{tabular}

